\title{
WestVirginiaUniversity
}

THE RESEARCH REPOSITORY @ WVU

Graduate Theses, Dissertations, and Problem Reports

2010

\section{Motivations, factors and issues concerning students at West Virginia University}

Jeremy L. Kelly

West Virginia University

Follow this and additional works at: https://researchrepository.wvu.edu/etd

\section{Recommended Citation}

Kelly, Jeremy L., "Motivations, factors and issues concerning students at West Virginia University" (2010). Graduate Theses, Dissertations, and Problem Reports. 2964.

https://researchrepository.wvu.edu/etd/2964

This Thesis is protected by copyright and/or related rights. It has been brought to you by the The Research Repository @ WVU with permission from the rights-holder(s). You are free to use this Thesis in any way that is permitted by the copyright and related rights legislation that applies to your use. For other uses you must obtain permission from the rights-holder(s) directly, unless additional rights are indicated by a Creative Commons license in the record and/ or on the work itself. This Thesis has been accepted for inclusion in WVU Graduate Theses, Dissertations, and Problem Reports collection by an authorized administrator of The Research Repository @ WVU. For more information, please contact researchrepository@mail.wvu.edu. 


\title{
Motivations, Factors and Issues Concerning Students at West Virginia University
}

\author{
Jeremy L. Kelly
}

Thesis submitted to the

Davis College of Agriculture, Natural Resources and Design

at West Virginia University

in partial fulfillment of the requirements

for the degree of

\author{
Master of Science \\ in \\ Agricultural and Extension Education
}

Harry N. Boone Jr., Ph.D., Chair

Deborah A. Boone, Ph.D.

Douglas D. LaVergne, Ph.D.

Division of Resource Management

Morgantown, West Virginia

2010

Keywords: Agricultural Education, Agriculture 


\section{ABSTRACT \\ Motivations, Factors and Issues Concerning Students \\ at West Virginia University \\ Jeremy L. Kelly}

Motivations take on different forms and strengths. There are many goals that students reach for, especially graduating with a degree. Throughout the years many individuals lose interest or get side tracked. The purpose of this study was to look at the many factors that motivate students to begin their education at West Virginia University, and the reasons that they stay. The study was limited to 320 students enrolled in the Agricultural and Extension Education courses 101, 110 and 220 for the 2010 spring semester. The final set of useable surveys numbered $281(90.9 \%)$. The students were presented an online survey, which was broken into five separate sections. Many of the findings included that the students' perceptions of the atmosphere at WVU encouraged students to pursue higher education. The study also found that the financial security that higher education provides is a determining factor to their pursing a college degree. 


\section{ACKNOWLEDGEMENTS}

There are many individuals that I want to thank for making this possible. I first want to thank Mr. Robert Born, my high school agriculture teacher. When I entered high school I had no idea what direction I was going in. Thankfully you were there to guide me in the right direction. It took a few years but I finally understood what you were getting at, and I am fully indebted to you for that.

Next, I want to thank Dr. Debby Boone. I entered college without a clue to what was going on. Luckily I was assigned to an academic advisor that went beyond just the call of duty. I would more than likely not be able to reach my dreams of graduating without your help. You were always there to listen and offer great advice.

I want to thank Dr. Harry Boone. No matter what the problem was or however many issues I had you were always there to help me out. It was a great experience getting to work with you and your professionalism. You have taught me a lot about education and how to truly be a professional.

I want to thank Dr. LaVergne for serving on my committee and offering many great ideas and solutions to the problems that arose.

Next, I want to thank my Mom for always being there for me and supporting me through the process of writing this thesis. Even when I didn't think that I could do you always said that I could, that meant a lot. Last, I want to thank my Dad. I know that you would be proud of me, and my accomplishments and that's what has kept me going for many years. 


\section{TABLE OF CONTENTS}

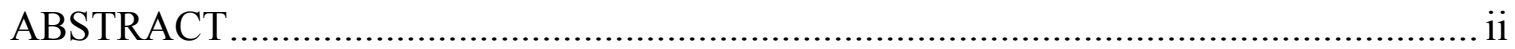

ACKNOWLEDGEMENTS .............................................................................. ii

TABLE OF CONTENTS .................................................................................... iv

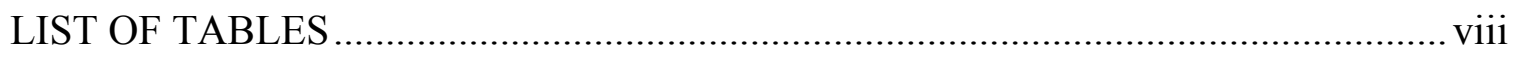

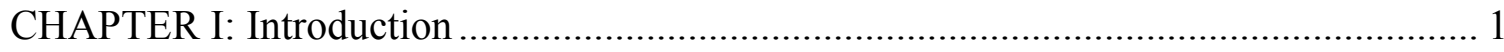

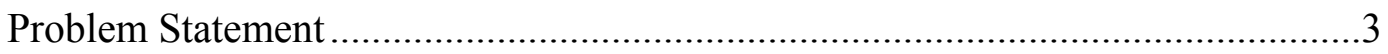

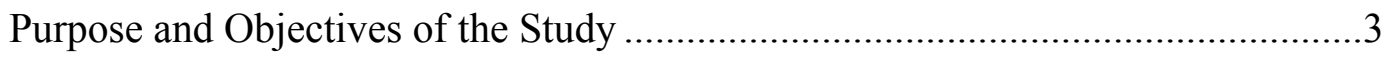

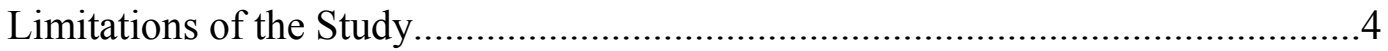

CHAPTER II: Review of Literature ..................................................................... 5

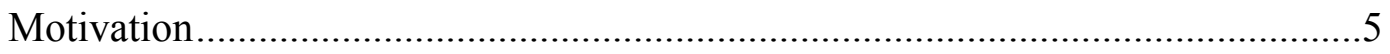

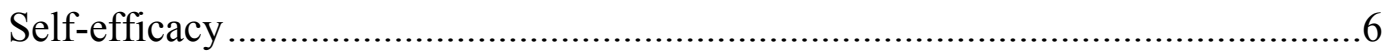

Motivational Beyond Education ...........................................................

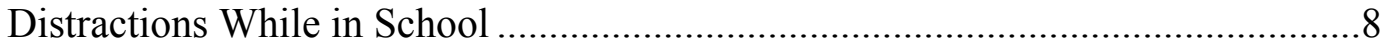

Drinking Motives ......................................................................................

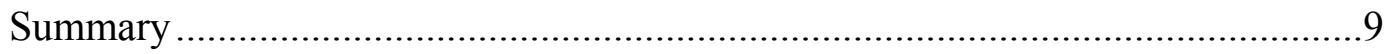

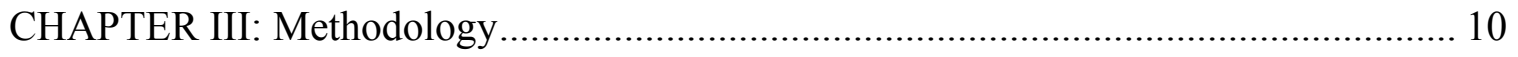

Purpose of the Study ............................................................................. 10

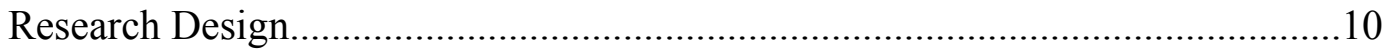

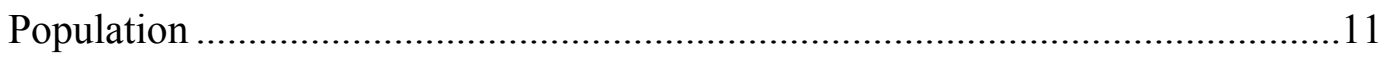

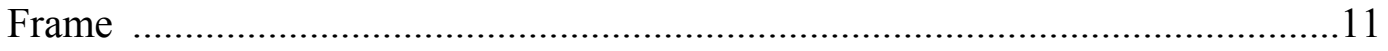

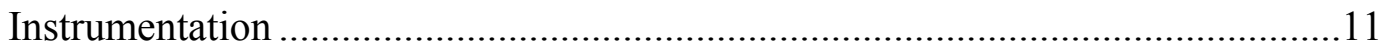




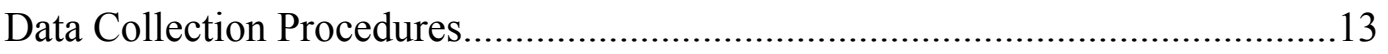

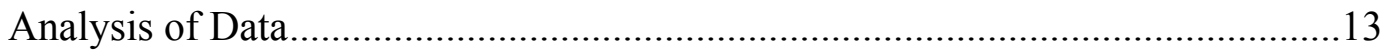

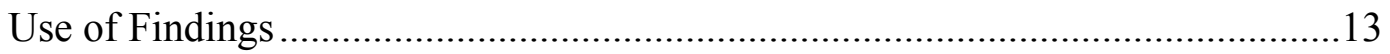

CHAPTER IV: Findings ....................................................................................... 14

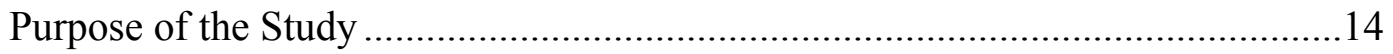

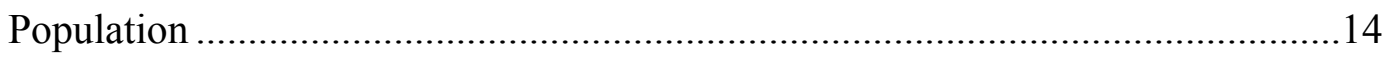

Demographic Characteristics of Respondents ..................................................15

Atmosphere Concerning Enrollment ..................................................................21

Career Oriented Decisions Concerning Enrollment …………………................23

Encouragement Concerning Enrollment.........................................................2

Personal Determination Involving Enrollment .................................................... 31

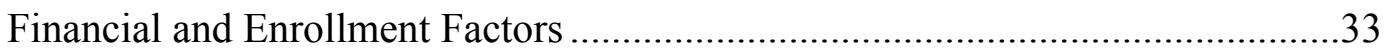

Factors that Kept Respondents Enrolled at WVU: Determination ..........................35

Educational Factors Affecting Continued Enrollment at WVU ..............................37

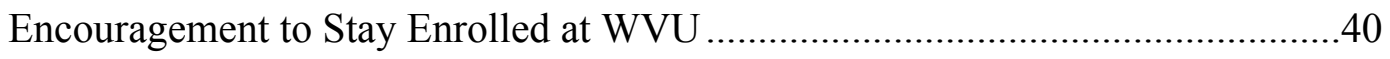

West Virginia University Resources.................................................................42

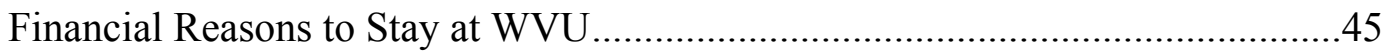

Location of WVU as a Factor Concerning Continual Enrollment........................47

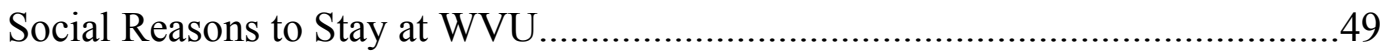

Career Decisions Concerning Possible Reasons to Leave WVU ...........................52

Difficulties and Grades Concerning Factors That May Cause Students to

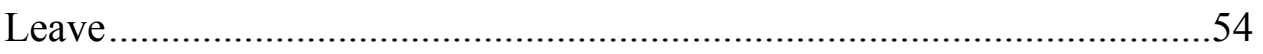

Discouragement as a Factor to Leave West Virginia University ............................55 
Family Issues Concerning Considerations to Leave WVU

Economic Reasons to Consider Leaving WVU ................................................59

Homesick or Personal Reasons for Considerations to Leave WVU .....................61

Faculty as Factors Affecting Consideration to Leave West Virginia

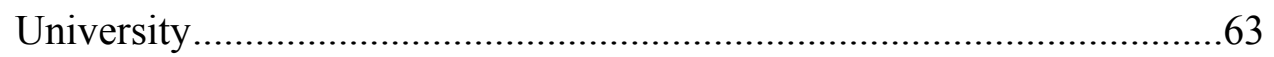

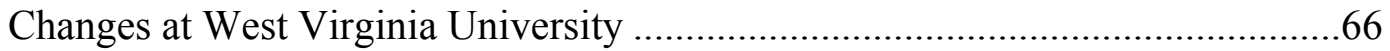

Recommended Financial Changes for WVU................................................69

Recommend Food Services Changes at WVU .................................................71

Recommended Relationship Changes at WVU ...............................................74

Recommended Faculty/Teacher Changes at WVU .......................................74

Recommended Transportation Changes at WVU ..............................................76

Academic Challenges that Faced Respondents..............................................78

Facility Issues That Faced Respondents ..................................................... 79

Family/Homesick Issues That Faced Students at WVU ...................................80

Motivational Issues That Faced Respondents.................................................83

Personal Issues that Challenged Student at West Virginia University ..................85

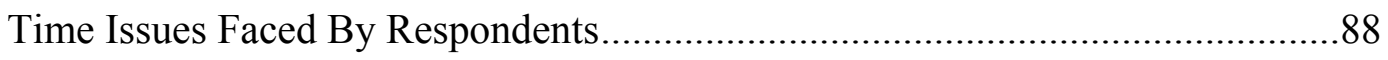

Generalized Summary Statements Expressed by the Respondents .....................90

CHAPTER V: Summary, Conclusions, and Recommendations .................................. 94

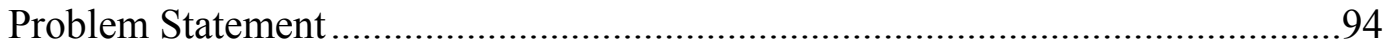

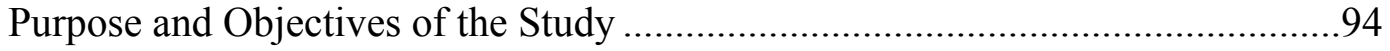

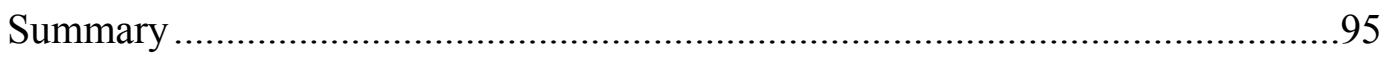

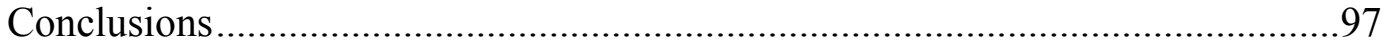


Recommendations.

REFERENCES

APPENDIX A: Email Correspondence .................................................................... 104

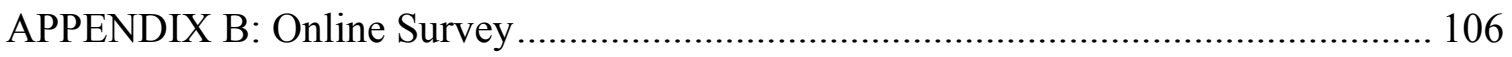

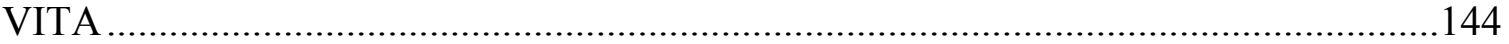




\section{LIST OF TABLES}

Table Title

Page

$1 \quad$ Age and State of Residence of Respondents................................................ 16

2 Grade Point Average and School of Respondents .............................................. 18

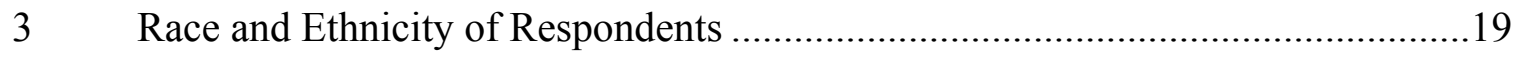

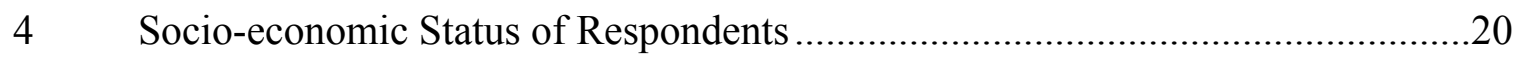

$5 \quad$ Number of First Generation Students Among Participants ...............................20

6 High School Advanced Placement Classes Completed by Respondents..............21

$7 \quad$ Atmosphere Factors Affecting Enrollment of Respondents ..............................24

8 Career Decisions Factors Affecting Enrollment of Respondents .......................26

9 Encouragement Factors Affecting Enrollment of Respondents.........................28

10 Independence Factors Affecting Enrollment of Respondents ............................30

11 Determination Factors Effect on Enrollment of Respondents .............................32

12 Financials Factors Effect on Continued Enrollment at West Virginia

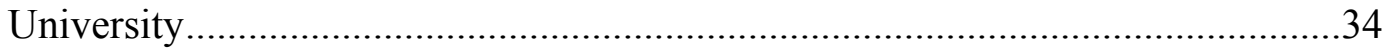

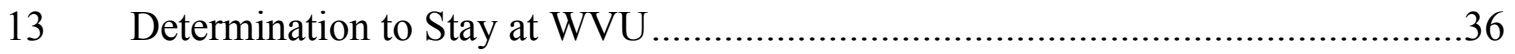

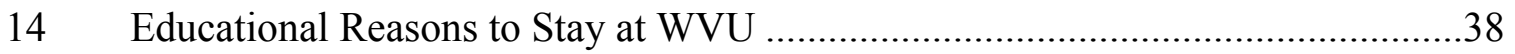

15 Encouragement Factors that Kept Students Enrolled at West Virginia

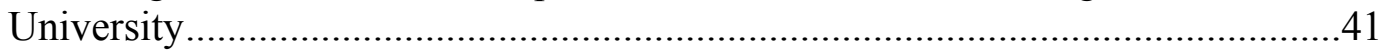

16 Resources Available to Students as a Factor to Stay at West Virginia University......

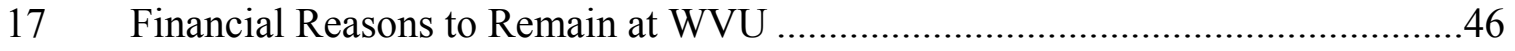

18 Location of WVU as a Factor Concerning Continual Enrollment........................48

19 Social/Atmosphere as a Factor to Remain at West Virginia University................50

20 Career Decisions as a Factor to Leave West Virginia University ........................53

21 College Atmosphere as a Factor to Leave West Virginia University ...................53 
22 Difficulties/Grades as a Factor to Leave West Virginia University .56

23 Discouragement as a Factor to Leave West Virginia University..........................58

24 Family as a Factor to Leave West Virginia University....................................58

25 Financials Factors Affecting Consideration to Leave West Virginia University

26 Homesick/Personal Factors Affecting Consideration to Leave West

Virginia University

27 Faculty as Factors Affecting Consideration to Leave West Virginia

University

28 Student Recommendations for Class Changes at West Virginia University

29 Student Recommendations for Financial Changes at West Virginia University

30 Student Recommendations for Food/Services Changes at West Virginia University .73

31 Student Recommendations for Relationship Changes at West Virginia University...... .75

32 Student Recommendations for Faculty Changes at West Virginia University

33 Student Recommendations for Transportation Changes at West Virginia University.

34 Academic Difficulties that Challenged Students at West Virginia University......

35 Facilities Issues that Challenged Students at West Virginia University.....

36 Family/homesick Issues that Challenged Students at West Virginia University

37 Motivation Issues that Challenged Students at West Virginia University .84

38 Personal Issues that Challenged Students at West Virginia University...... .86

39 Time Issues that Challenged Students at West Virginia University .89

$40 \quad$ Motivations to Pursue a Degree ................................................................. 90

41 Suggested Changes at West Virginia University 


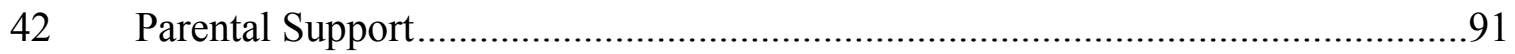

43 Individuals that Provided Encouragement ....................................................92

44 Study Techniques Used at West Virginia University ......................................93 


\section{CHAPTER I}

\section{Introduction}

Each year thousands of students begin their epic journey as they initiate their college careers. In the 1960's the United States attendance in college after high school for completers was 758,000 students. This was about $45 \%$ of the completers that graduated. In $2006,1,776,000$ entered college after high school. This was about $66 \%$ of the completers that graduated. These numbers have fluctuated for many years, however since 1997 the percentage of students entering college has fluctuated between 62 and 69 percent. A projected attendance for fall of 2008 was 1,820,000 in the United States for completers. The overall attendance for first-time freshmen in the United States was 2,707,213 (Snyder, Sally, \& Hoffman, 2009).

In 2009, West Virginia colleges had an expected incoming freshmen numbers at 15,807 (Snyder, Sally, \& Hoffman, 2009). West Virginia University's enrollment for the fall 2008 semester was over 28,000 including students from all 55 WV counties, 49 states, the District of Columbia, two territories, and 99 nations (Davis College of Agriculture, Natural Resources and Design, 2009).

College students come from a wide variety of backgrounds. These backgrounds and experiences shape who they are, their personalities and their dreams. Motivation, however, is the mechanism that drives one's own ability to carry out these dreams (Vansteenkiste, Soenens, \& Sierens, 2009). These dreams may be obtainable, but it's one's own self determination that enables these ideas to come true. Freshmen enter college with some level of motivation to succeed in their studies; however, students still 
drop-out and leave the University to pursue other avenues in life, while others stay and continue their academic career.

Maslow (1970) states that there are five levels of motivation: physiological, safety, love, esteem, and self actualization. Physiological needs have to be met prior to our minds to be motivated towards providing a safe environment. Safety must be met before pursuing love. This trend continues up the pyramid until self actualization can be met. "Once a certain need or set of needs become satisfied, it loses its potency as a motivating force until it again becomes manifest (or activated)" (Steers, 1979, p. 32). Motivation is thus changed towards satisfying personal hunger, once satisfied individuals can be motivated to look onward to something else.

Students consistently flow in and out of each motivational level. There are many things that affect a person's motivational intensity. "Another peculiar characteristic of the human organism when it is dominated by a certain need is that the whole philosophy of the future tends also to change" (Maslow, 1970, p. 37). Students work towards a common goal but often motivational needs get in the way of their immediate futures, they have to make changes to their environment and overcome many obstacles. ...for our chronically and extremely hungry man, Utopia can be defined simply as a place where there is plenty of food. He tends to think that, if only he is guaranteed food for the rest of his life, he will be perfectly happy and will never want anything more (Maslow, 1970, p. 37).

If a student has a strong motivation towards graduation many of the aforementioned levels may be compromised, but if a student has a low motivation due to many factors this may affect their future goals. 


\section{Problem Statement}

High school students throughout the world are making drastic decisions that will inevitably steer their life directions; decisions on where to go to college, what degree to pursue, or even if they want to go to college at all. Focusing efforts on what motivates students to choose West Virginia University will give insight into what can be expanded on to encourage more students to enroll. However, there are many issues that pull students away from the University once getting here and understanding their motives to stay and considerations on leaving will give the University some insight to the issues that students are dealing with today.

\section{Purpose and Objectives of the Study}

The purpose of this study was to determine the motivational forces that encourage students to enroll at West Virginia University. It was also designed to understand what motivated the students to continue to pursue their degrees. This study will be helpful in finding and understanding key motivational factors that encourage students to enroll at WVU. The study will also help professors and advisors better understand their students and help them in developing a better understanding of student issues.

The objectives of the study are reflected in the following research questions:

1. What are the factors that have motivated students to continue their education beyond high school?

2. What factors have challenged students during their college career?

3. What are the issues students face when dealing with West Virginia University? 
4. What are the factors, if any, that have caused the student to reconsider their position at the University?

5. What factors kept the students at West Virginia University?

\section{Limitations of the Study}

The study is limited to students enrolled in the Agricultural and Extension Education courses 101, 110 and 220 for the 2010 spring semester. 


\section{CHAPTER II}

\section{Review of Literature}

Individuals have different reasons to being motivated. They have different levels of motivation by which they pursue a level of self actualization. There are many issues at a psychological level in which motivation and self encouragement comes into play. Many people spend a lifetime researching and developing how motivation affects the psyche.

\section{Motivation}

Maslow (1970) found that motivations are built in a pyramid like schema with physiological needs at the base. Maslow (1970) says that one is not or cannot be motivated beyond physiological needs until they are satisfied in one's mind. Having a home, clean place to sleep, and shelter are example of these needs. Once physiological needs are met then one could move up the pyramid to safety. Once safety is satisfied, then one could move further up to belongingness and love, then to esteem, then further to the pinnacle of the pyramid, self-actualization. Maslow says that each of these levels can become heightened depending on many factors, such as hunger. It may become stronger and stronger and more persistent depending on the situation. If one knows that food is waiting at home then one's mind can be focused on something else, however if one is stuck in the desert, finding shelter and food takes precedence.

There are many different theories behind motivation. "Hull postulated that at birth the behavior of organisms is the result of inherited, neural connections between receptors and effectors" (Weiner, 1972, p. 23). Weiner (1972) states that as motivations continue through the organism's life-span they learn to develop them into hierarchies. 
One example of an unlearned response is the moving away from an annoying stimulus. As one continues to develop through its lifetime it learns to stay clear of this stimulus if annoying enough.

\section{Self-efficacy}

Self-efficacy is a students' own belief whether they can perform a task or not.

“These self-reported perceptions of capability are significantly predictive of teachers' observations of their students' self-regulatory behavior in class (Zimmerman \& Kitsantas, 2007, p. 62). This develops the idea further that most students do understand that their own self-motivation can be seen and is predictive as to what their school work is going to be. If one has a strong self-efficacy in one domain they are likely to do well in that area, but can it be transferred to another subject area? "However, many teachers and parents still maintain the mistaken belief that student motivation is part of global personality traits and hence students are either motivated or unmotivated across all learning situations" (Bong, 2004, p. 288). There are many ideas that separate educational domains and that students maintain their own self-efficacy, however Bong (2004) states that even though students feel comfortable in two subjects they would not blame one or the other for their success or failure in both domains. Students who are comfortable in one subject area and not the other do not blame their failures on the others class material.

"Self regulated learners have a large arsenal of cognitive and meta cognitive strategies that they readily deploy, when necessary, to accomplish academic strategies" (Wolters, 1998, p. 224) Often this self-regulation allows for the development of different levels of motivation. If one has a strong idea that grades are important then they may pull from their knowledge different strategies to stay on subject to achieve a high grade. 
Wolters (1998) states that student's motivations change depending on the subject and need.

Motivation takes many forms. There are different reasons to continue ones education or a student's interest and this often comes with a magnitude of motivational levels.

Most motivation psychologists, teachers, and parents would agree that students' study behavior is multi-determined. Multiple reasons might drive study behavior, such as spontaneous interest in the learning material, a desire to prove oneself by getting high grades, external expectations, or future professional goals ... different groups or types of students might exist that are characterized by different motivational profiles.

(Vansteenkiste, Soenens \& Sierens, 2009, p. 671)

\section{Motivational Beyond Education}

College students are faced with many decisions as they enter their first year of college. Social substructures often encourage and heighten motivations. One motivation that is often a concern of some colleges is the motives to drink. "The positively reinforcing motive of social and enhancement had the strongest relationships with the measures of alcohol use, suggesting that being motivated to use alcohol for reasons such as enjoying a party...” (Martens, Rocha, Martin, \& Serrao, 2008, p. 293). Students, who try to fill their belongingness levels of Maslow's hierarchy often fall trap to social situations often causing ones motivation to drink to heighten.

Due to the various economic situations students are finding themselves helping more and more towards paying for their education. Students who work less than 25 hours 
per week have little effect on their grade point averages. However, if these students continue working at this level they do increase their probability of increasing their time in college, moving the graduation up. "Working on-campus increases the chance of students continuing their education beyond graduation" (Ehrenberg \& Sherman, 1987, p. 17). This provides the idea that students who work during their schooling are often motivated else-where. If one worked off campus they have a tendency to stray away from school, or handle fewer classes.

\section{Distractions While in School}

Ehrenberg and Sherman (2009) found that freshmen that worked 20 plus hours a week had a probability of 6.6 percentage points higher to drop out versus a student who is not employed. They also discovered that sophomores working the same hours have a slightly higher probability of dropping out, 7.3 percentage points above the students who did not work at all. Ehrenberg and Sherman (2009) also found that third and fourth year students that worked 20 plus hours had a considerable drop out difference then first and second year students with 3.0 percentage points above the students who have had no job.

\section{Drinking Motives}

Students have a tendency to drink alcohol while in college, sometimes it is encouraged through friends, or even their own self motivation. Martens, Rocha, Martin, \& Serrao (2008) found that enhancement motives accounted for seven to 17 percent of the variance and eight to 14 percent of the variance in the alcohol-use measures. Coping motives accounted for around four percent of the variance in these measures and conformity motives accounted for only one to three percent of the variance. 


\section{Summary}

Students are often pulled in different directions in college depending on a wide range of things, such as parental support, financial needs, and self determination. As students in college there are many issues that they have to face, sometimes things have to take precedence over others. Motivation is highly complex with many different factors leading to success as well as failure. 


\section{CHAPTER III}

\section{Methodology}

\section{Purpose of the Study}

The purpose of this study was to determine the motivational forces that encourage students to enroll at West Virginia University. It was also designed to understand what motivated the students to continue to pursue their degrees. This study will be helpful in finding and understanding key motivational factors that encourage students to enroll at WVU. The study will also help professors and advisors better understand their students and help them in developing a better understanding of student issues.

The objectives of the study are reflected in the following research questions:

1. What are the factors that have motivated students to continue their education beyond high school?

2. What factors have challenged students during their college career?

3. What are the issues students face when dealing with West Virginia University?

4. What are the factors, if any, that have caused the student to reconsider their position at the University?

5. What factors kept the students at West Virginia University?

\section{Research Design}

A descriptive research design in the form of an online questionnaire was used to gather information from the participants. Internet based questionnaires, have the potential of reaching large populations and permit the collection of larger amounts (Ary, 
Jacobs, Razavieh, \& Sorensen, 2006). Since the participants had access to this type of technology an Internet questionnaire was an easy way to access a large audience. This design allows the student to have a piece of mind that their answers will be kept in confidence.

\section{Population}

The target population of the study consisted of students attending West Virginia University during the spring 2010 semester. Due to confidentiality of student records, the accessible population was 320 students enrolled in Agricultural and Extension Education 110,101 , and 220 courses.

\section{Frame}

Sampling error was not an issue due to the fact that this is a purposeful population. Frame error was not an issue because the population was generated from official class rosters. Selection error was eradicated by generating a list of student emails from all classes and deleting multiples. To eliminate measurement error the reliability and validity of the instrument was established. This survey was designed for complete discretion which prevented the students from giving socially acceptable answers.

\section{Instrumentation}

A variation of the modified Delphi technique was used to generate the questionnaire. In step one, students from the graduate colloquium course for Agricultural and Extension Education class were asked to identify issues they were facing when dealing with the University. These responses were developed into five questions/objectives of this study. 
1. What are the factors that have motivated students to continue their education beyond high school?

2. What factors have challenged students during their college career?

3. What are the issues students face when dealing with West Virginia University?

4. What are the factors, if any, that have caused the student to reconsider their position at the University?

5. What factors kept the students at West Virginia University?

During step two, a group of students were asked to answer the five questions, using an online survey. The results were compiled and categorized by frequency. The most frequently used responses were used to develop an instrument of Likert scale items.

The instrument was presented to a panel of experts to establish its content and face validity. The panel of experts consisted of professors in the Agricultural and Extension Education Department. Each individual on the panel had extensive experience in research at the land grant university. The panel concluded the instrument had content and face validity.

Reliability of the instrument was determined using the final data set from all respondents. Because the data consisted of nominal and ordinal scale responses based on the likert scale, Spearman-Brown Split half statistic was used to establish the instrument's reliability. Reliability was found to be exemplary with a coefficient of .4261 (Robinson, Shaver, \& Wrightsman, 1991). The instrument was established as a reliable measure. 


\section{Data Collection Procedures}

The data and information collection method in this study included a questionnaire that was delivered online using Zoomerang ${ }^{\circledR}$. An initial email was sent to each participant that included a cover letter and the link to the online survey. The population was given 10 days to complete the survey. At the end of the seventh day a reminder email was sent out. At the end of the ten day period a second email was sent out with the original cover letter, a paragraph explaining to them the importance of the survey, and instructions to only fill it out once. Students were given another 10 day period to complete the questionnaire with a follow-up email at the end of the seventh day. Early and late respondents were tracked.

\section{Analysis of Data}

Returned questionnaires were examined and entered into an Excel spreadsheet. The data was transferred to the personal computer version of the Statistical Package for the Social Sciences (SPSS). The level of significance was set a priori at $\alpha \leq .05$ for all statistical tests. Descriptive analyses were performed on the data. Frequency tables were used for Likert items.

\section{Use of Findings}

The findings can be used by deans, professors, instructors, and recruiting officers for the University to consider changes to academic endeavors and changes to the University layout that may be more advantageous to the student body. Through this study one can understand what students may be facing as a student at the University. 


\section{CHAPTER IV}

\section{Findings}

\section{Purpose of the Study}

The purpose of this study was to determine the motivational forces that encourage students to enroll at West Virginia University. It was also designed to understand what motivated the students to continue to pursue their degrees. This study will be helpful in finding and understanding key motivational factors that encourage students to enroll at WVU. The study will also help professors and advisors better understand their students and help them in developing a better understanding of student issues.

The objectives of the study are reflected in the following research questions:

1. What are the factors that have motivated students to continue their education beyond high school?

2. What factors have challenged students during their college career?

3. What are the issues students face when dealing with West Virginia University?

4. What are the factors, if any, that have caused the student to reconsider their position at the University?

5. What factors kept the students at West Virginia University?

\section{Population}

The accessible population consisted of 309 students currently enrolled in AGEE 101, 110 and 220 at West Virginia University for the spring 2010 semester. Two hundred eighty-two questionnaires $(91.2 \%)$ were completed. Of the 282 questionnaires completed, one was unusable. The final set of useable surveys numbered $281(90.9 \%)$. 


\section{Demographic Characteristics of Respondents}

Using a total of four categories participants were asked to indicate their age. The median age range was $18-21$ years of age. One hundred forty-two respondents $(53.8 \%)$ indicated their age was between the ages of 18 through 21 . One hundred ten individuals (41.7\%) identified themselves as being in the 21-24 age range. Eight respondents $(3.0 \%)$ identified themselves in the 25-27 year range. The 28 and up category included four respondents $(1.5 \%)$ (see Table 1$)$.

Of the respondents $155(59.8 \%)$ indicated that they were from the state of West Virginia. Thirty-nine respondents (15.1\%) indicated that they were from Pennsylvania, while 22 individuals $(8.5 \%)$ indicated Maryland as their state of residence. Twelve participants $(4.6 \%)$ were from Ohio. Ten respondents $(3.9 \%)$ indicated they were from New Jersey. Six respondents $(2.3 \%)$ were from Virginia, while New York was indicated by five individuals $(1.9 \%)$. Three respondents $(.13 \%)$ indicated they were from an international location, while two participants $(.8 \%)$ indicated they were from Florida. The states of California, Delaware, Indiana, North Carolina and South Carolina each had one respondent (.4\%) (see Table 1$)$.

Ninety-six respondents (36.6\%) indicated that their grade point average was between 3.5 and 4.0. One hundred three individuals (39.3\%) indicated that their grade point average was between 3.0 and 3.49. Fifty-five respondents $(21.0 \%)$ indicated they had between a 2.5 and 2.9 grade point average. Eight respondents $(3.1 \%)$ indicated they had a 2.4 grade point average and below (see Table 2). 
Table 1

Age and State of Residence of Respondents

\begin{tabular}{|c|c|c|}
\hline & $\mathrm{N}$ & $\%$ \\
\hline \multicolumn{3}{|l|}{ Age } \\
\hline $18-20$ & 142 & 53.8 \\
\hline $21-24$ & 110 & 41.7 \\
\hline $25-27$ & 8 & 3.0 \\
\hline 28 and up & 4 & 1.5 \\
\hline \multicolumn{3}{|l|}{ State } \\
\hline West Virginia & 155 & 59.8 \\
\hline Pennsylvania & 39 & 15.1 \\
\hline Maryland & 22 & 8.5 \\
\hline Ohio & 12 & 4.6 \\
\hline New Jersey & 10 & 3.9 \\
\hline Virginia & 6 & 2.3 \\
\hline New York & 5 & 1.9 \\
\hline International & 3 & .13 \\
\hline Florida & 2 & .8 \\
\hline California & 1 & .4 \\
\hline Delaware & 1 & .4 \\
\hline Indiana & 1 & .4 \\
\hline North Carolina & 1 & .4 \\
\hline South Carolina & 1 & .4 \\
\hline
\end{tabular}


One hundred ten respondents (42.3\%) were from the Davis College of Agriculture, Natural Resources, and Design. Forty-one individuals (15.8\%) were from the School of Nursing. College of Engineering and Mineral Resources had 30 respondents (11.5\%) and 25 respondents (9.6\%) indicated that they were from the Eberly College of Arts and Sciences. Twenty-one respondents (8.1\%) identified themselves as being part of the College of Business and Economics. Fourteen respondents (5.4\%) indicated they were from the School of Medicine, while the College of Human Resources and Education had 9 respondents (3.5\%). Six respondents (2.3\%) indicated they were part of the College of Physical Activity and Sport Sciences. The College of Creative Arts and the School of Pharmacy both had two respondents (.8\%) (see Table 2).

Two hundred forty-nine respondents (95.8\%) indicated they were best described as white or Caucasian. The Black-African American and Asian categories had five respondents (1.9\%) each and the American Indian or Alaskan Native category had one respondent (.4\%). Four respondents (1.6\%) indicated they were of the Hispanic or Latino ethnicity, while 241 individuals (98.4\%) indicated they were Non-Hispanic or Latino (see Table 3). 
Table 2

Grade Point Average and School of Respondents

\begin{tabular}{|c|c|c|}
\hline & $\mathrm{N}$ & $\%$ \\
\hline \multicolumn{3}{|l|}{ Grade Point Average } \\
\hline $3.5-4.0$ & 96 & 36.6 \\
\hline $3.0-3.49$ & 103 & 39.3 \\
\hline $2.5-2.9$ & 55 & 21.0 \\
\hline Below - 2.4 & 8 & 3.1 \\
\hline \multicolumn{3}{|l|}{ School } \\
\hline $\begin{array}{l}\text { Davis College of Agriculture, Natural } \\
\text { Resources, and Design }\end{array}$ & 110 & 42.3 \\
\hline School of Nursing & 41 & 15.8 \\
\hline $\begin{array}{l}\text { College of Engineering and Mineral } \\
\text { Resources }\end{array}$ & 30 & 11.5 \\
\hline Eberly College of Arts and Sciences & 25 & 9.6 \\
\hline College of Business and Economics & 21 & 8.1 \\
\hline School of Medicine & 14 & 5.4 \\
\hline $\begin{array}{l}\text { College of Human Resources and } \\
\text { Education }\end{array}$ & 9 & 3.5 \\
\hline $\begin{array}{l}\text { College of Physical Activity and Sport } \\
\text { Sciences }\end{array}$ & 6 & 2.3 \\
\hline College of Creative Arts & 2 & .8 \\
\hline School of Pharmacy & 2 & .8 \\
\hline
\end{tabular}


Table 3

Race and Ethnicity of Respondents

\begin{tabular}{lcc}
\hline & $\mathrm{N}$ & $\%$ \\
\hline Race & 1 & .4 \\
American Indian or Alaskan Native & 5 & 1.9 \\
Asian & 5 & 1.9 \\
Black-African American & 249 & 95.8 \\
White-Caucasian & & \\
Ethnicity & 4 & 1.6 \\
Hispanic or Latino & 241 & 98.4 \\
Non-Hispanic or Latino & & \\
\hline
\end{tabular}

One hundred eleven individuals (42.4\%) indicated they belonged in the upper middle class socio-economic status. Eighty respondents $(30.5 \%)$ indicated they were in the lower middle class. Fifty-three individuals (20.2\%) belonged in the working economic status, while 13 respondents $(5.0 \%)$ indicated they were in the working poor category. Five respondents $(1.9 \%)$ were in the underclass socio economic status (see Table 4). 
Table 4

Socio-economic Status of Respondents

\begin{tabular}{lcc}
\hline & $\mathrm{N}$ & $\%$ \\
\hline Upper Middle & 111 & 42.4 \\
Lower Middle & 80 & 30.5 \\
Working & 53 & 20.2 \\
Working Poor & 13 & 5.0 \\
Underclass & 5 & 1.9 \\
\hline
\end{tabular}

One hundred ninety-seven individuals (70.4\%) indicated that they were not first generation college students. Eighty-three respondents (29.6\%) indicated that they were first generation college students (see Table 5).

Table 5

Number of First Generation Students Among Participants

\begin{tabular}{lcc}
\hline & $\mathrm{N}$ & $\%$ \\
\hline No & 197 & 70.4 \\
Yes & 83 & 29.6 \\
\hline
\end{tabular}

One hundred twenty-three respondents $(43.9 \%)$ indicated that they had not taken advanced placement classes in high school, while 157 individuals $(56.1 \%)$ indicated that they had taken advanced placement classes. When asked if they were helpful for their preparation for college, 182 respondents $(65.0 \%)$ indicated that the classes were not helpful, while 98 respondents (35\%) indicated that they were. 
Table 6

High School Advanced Placement Classes Completed by Respondents

\begin{tabular}{lcc}
\hline & $\mathrm{N}$ & $\%$ \\
\hline Advance placement classes & 123 & \\
No & 157 & 43.9 \\
Yes & & 56.1 \\
Advance placement classes helpful? & 182 & 65.0 \\
No & 98 & 35.0 \\
Yes & 98 \\
\hline
\end{tabular}

\section{Atmosphere Concerning Enrollment}

The respondents were asked their opinions on a number of factors that affected their enrollment at West Virginia University. The questions were grouped into six different categories. Respondents expressed their opinions using a five point Likert scale with 1 being "strongly agree", 2 "agree" , 3 “disagree", 4 "strongly disagree", and 5 "not applicable". Eight questions were based around the atmosphere that affected enrollment decisions. A majority of the respondents $(\mathrm{N}=208,74.2 \%)$ agree that athletics were important to them as a spectator with 132 respondents (47.1\%) expressing agreement and 76 expressing strong agreement $(27.1 \%)$ with the statement (see Table 7 ). Forty-seven respondents (16.8\%) disagreed with the statement and 23 individuals (8.2\%) expressed strong disagreement. Two individuals (.7\%) indicated that it was not applicable to them.

Fifty-two respondents (27.1\%) strongly agreed that athletics were important to them as participants while 57 individuals (20.4\%) agreed with the statement. Fifty-nine respondents $(21.1 \%)$ disagreed with the statement and 31 individuals (11.1\%) expressed 
strong disagreement. Eighty respondents (28.7\%) responded it was not applicable to them.

One hundred seventeen respondents (41.9\%) strongly agreed that they wanted the opportunity to meet new people while 147 individuals (52.7\%) agreed with the statement. Eleven respondents (3.9\%) disagreed with the statement and two individuals (.7\%) expressed strong disagreement. Two respondents $(.7 \%)$ indicated that it was not applicable to them.

Seventy-three respondents (26.3\%) strongly agreed that they wanted to be part of the WVU social system while 163 individuals (60.4\%) agreed with the statement. Thirtytwo respondents (11.5\%) disagreed with the statement and five individuals (1.8\%) expressed strong disagreement (see Table 7).

A majority of the respondents $(\mathrm{N}=147,52.9 \%)$ agreed that they wanted to party with 33 respondents (11.9\%) expressing strong agreement and 114 individuals $(41.0 \%)$ expressing agreement with the statement. Seventy-eight respondents (28.1\%) disagreed with the statement and 50 individuals (18.0\%) expressed strong disagreement. Three individuals (1.1\%) indicated that the statement did not apply to them

Ninety-two respondents (33.0\%) strongly agreed that many of their friends went to college while 130 individuals (46.6\%) agreed with the statement. Thirty-nine respondents (14.0\%) disagreed with the statement and 17 individuals (6.1\%) expressed strong disagreement. One individual (.4\%) indicated that the statement did not apply.

One hundred fifteen respondents (41.2\%) strongly agreed that the college experience intrigued them while 143 individuals (51.3\%) agreed with the statement. 
Nineteen respondents (6.8\%) disagreed with the statement and two individuals (.7\%) strongly disagreed.

One hundred nineteen respondents (42.8\%) strongly agreed that the overall atmosphere at WVU was welcoming while 147 individuals (52.9\%) agreed with the statement. Ten respondents (3.6\%) disagreed with the statement while two individuals (.7\%) expressed strong disagreement (see Table 7).

\section{Career Oriented Decisions Concerning Enrollment}

Seven career orientated statements were presented to the respondents. A majority of the respondents $(\mathrm{N}=266,95.0 \%)$ agreed that a college degree was required to reach their career goals with 207 respondents (73.9\%) expressing strong agreement and 59 individuals (21.1\%) expressing agreement with the statement. Eleven individuals (3.9\%) disagreed with the statement while two respondents (.7\%) expressed strong disagreement. One individual (.4\%) indicated that the statement did not apply to them.

Two hundred nineteen students $(78.2 \%)$ strongly agreed with the statement that a college education-degree was a personal goal while 53 individuals (18.9\%) agreed with the statement. Eight respondents (2.9\%) disagreed with statement. 
Table 7

Atmosphere Factors Affecting Enrollment of Respondents

\begin{tabular}{|c|c|c|c|c|c|c|c|c|c|c|}
\hline & \multicolumn{2}{|c|}{ Strongly Agree } & \multicolumn{2}{|c|}{ Agree } & \multicolumn{2}{|c|}{ Disagree } & \multicolumn{2}{|c|}{ Strongly Disagree } & \multicolumn{2}{|c|}{ Not Applicable } \\
\hline & $\mathrm{N}$ & $\%$ & $\mathrm{~N}$ & $\%$ & $\mathrm{~N}$ & $\%$ & $\mathrm{~N}$ & $\%$ & $\mathrm{~N}$ & $\%$ \\
\hline $\begin{array}{l}\text { Athletics were important to me as a } \\
\text { spectator }\end{array}$ & 76 & 27.1 & 132 & 47.1 & 47 & 16.8 & 23 & 8.2 & 2 & .7 \\
\hline $\begin{array}{l}\text { Athletics were important to me as a } \\
\text { participant }\end{array}$ & 52 & 18.6 & 57 & 20.4 & 59 & 21.1 & 31 & 11.1 & 80 & 28.7 \\
\hline $\begin{array}{l}\text { I wanted the opportunity to meet } \\
\text { new people }\end{array}$ & 117 & 41.9 & 147 & 52.7 & 11 & 3.9 & 2 & .7 & 2 & .7 \\
\hline $\begin{array}{l}\text { I wanted to be a part of the WVU } \\
\text { social system }\end{array}$ & 73 & 26.3 & 168 & 60.4 & 32 & 11.5 & 5 & 1.8 & 0 & .0 \\
\hline I wanted to party & 33 & 11.9 & 114 & 41.0 & 78 & 28.1 & 50 & 18.0 & 3 & 1.1 \\
\hline $\begin{array}{l}\text { Many of my friends went to } \\
\text { college }\end{array}$ & 92 & 33.0 & 130 & 46.6 & 39 & 14.0 & 17 & 6.1 & 1 & .4 \\
\hline $\begin{array}{l}\text { The college experience intrigued } \\
\text { me }\end{array}$ & 115 & 41.2 & 143 & 51.3 & 19 & 6.8 & 2 & .7 & 0 & .0 \\
\hline $\begin{array}{l}\text { The overall atmosphere at WVU } \\
\text { was welcoming }\end{array}$ & 119 & 42.8 & 147 & 52.9 & 10 & 3.6 & 2 & .7 & 0 & .0 \\
\hline
\end{tabular}


Eighty-two respondents (29.9\%) strongly agreed with the statement that they wanted to help others while 150 individuals (54.7\%) expressed agreement with the statement. Thirty-one respondents (11.3\%) disagreed with the statement while six individuals (2.2\%) expressed strong disagreement. Five individuals (1.8\%) indicated that the statement did not apply to them.

Seventy-eight respondents (28.5\%) strongly agreed with the statement that they wanted to serve as a role model while 144 individuals (52.6\%) agreed with the statement. Forty respondents (14.6\%) disagreed with the statement while eight individuals (2.9\%) expressed strong disagreement. Four individuals indicated (1.5\%) that the statement did not apply to them.

Thirty-seven respondents (13.6\%) strongly agreed with the statement that they wanted to try a different career path while 112 individuals (41.0\%) agreed with the statement. Seventy-one respondents (26.0\%) disagreed with the statements while 14 individuals (5.1\%) expressed strong disagreement. Thirty-nine individuals (14.3\%) indicated that the statement did not apply to them (see Table 8).

One hundred thirty respondents (48.3\%) strongly agreed with the statement that they were interested in expanding their knowledge in a specific subject area while 131 individuals agreed with the statement. Six respondents (2.2\%) disagreed with the statement while one individual (.4\%) expressed strong disagreement. One individual (.4\%) indicated that the statement did not apply to them. 
Table 8

Career Decisions Factors Affecting Enrollment of Respondents

\begin{tabular}{|c|c|c|c|c|c|c|c|c|c|c|}
\hline & \multicolumn{2}{|c|}{ Strongly Agree } & \multicolumn{2}{|c|}{ Agree } & \multicolumn{2}{|c|}{ Disagree } & \multicolumn{2}{|c|}{ Strongly Disagree } & \multicolumn{2}{|c|}{ Not Applicable } \\
\hline & $\mathrm{N}$ & $\%$ & $\mathrm{~N}$ & $\%$ & $\mathrm{~N}$ & $\%$ & $\mathrm{~N}$ & $\%$ & $\mathrm{~N}$ & $\%$ \\
\hline $\begin{array}{l}\text { A college degree was required to } \\
\text { reach my career goals }\end{array}$ & 207 & 73.9 & 59 & 21.1 & 11 & 3.9 & 2 & .7 & 1 & .4 \\
\hline $\begin{array}{l}\text { A college education-degree was a } \\
\text { personal goal }\end{array}$ & 219 & 78.2 & 53 & 18.9 & 8 & 2.9 & 0 & .0 & 0 & .0 \\
\hline I wanted to be able to help others & 82 & 29.9 & 150 & 54.7 & 31 & 11.3 & 6 & 2.2 & 5 & 1.8 \\
\hline I wanted to serve as a role model & 78 & 28.5 & 144 & 52.6 & 40 & 14.6 & 8 & 2.9 & 4 & 1.5 \\
\hline $\begin{array}{l}\text { I wanted to try a different career } \\
\text { path }\end{array}$ & 37 & 13.6 & 112 & 41.0 & 71 & 26.0 & 14 & 5.1 & 39 & 14.3 \\
\hline $\begin{array}{l}\text { I was interested in expanding my } \\
\text { knowledge in a particular subject } \\
\text { area }\end{array}$ & 130 & 48.3 & 131 & 48.7 & 6 & 2.2 & 1 & .4 & 1 & .4 \\
\hline $\begin{array}{l}\text { There were many career } \\
\text { opportunities associated with my } \\
\text { degree }\end{array}$ & 127 & 46.4 & 121 & 44.2 & 19 & 6.9 & 3 & 1.1 & 4 & 1.5 \\
\hline
\end{tabular}


A majority of the respondents $(\mathrm{N}=248,90.6 \%)$ agreed that there are many career opportunities associated with their degrees with 127 respondents (46.4\%) expressing strong agreement and 121 individuals (44.2\%) expressing agreement with the statement. Nineteen respondents $(6.9 \%)$ disagreed with the statement while three $(1.1 \%)$ expressed strong disagreement. Four individuals (1.5\%) indicated that the statement was not applicable to them (see Table 8).

\section{Encouragement Concerning Enrollment}

Four encouragement statements regarding enrollment were presented to the participants. Forty-five respondents (16.4\%) strongly agreed with the statement that it was tradition to attend college and 75 individuals (27.4\%) indicated that they agreed with the statement. Ninety-six respondents (35.0\%) disagreed with the statement while 51 individuals (18.6\%) expressed strong disagreement. Seven individuals (2.6\%) indicated that the statement was not applicable to them.

A majority of the respondents $(\mathrm{N}=259,95.2 \%)$ agreed that their family encouraged them to attend college with 180 respondents (66.2\%) expressing strong agreement and 79 individuals (29.0\%) expressing agreement with the statement. Thirteen respondents (4.8\%) disagreed with the statement.

One hundred forty-three respondents (52.6\%) strongly agreed with the statement that their grandparents encouraged them to attend college while 74 individuals (27.2\%) expressed agreement with the statement. Thirty-one respondents (11.4\%) disagreed with the statement while 12 individuals (4.4\%) expressed strong disagreement. Twelve individuals (4.4\%) indicated that the statement was not applicable to them. 
Table 9

Encouragement Factors Affecting Enrollment of Respondents

\begin{tabular}{lcccccccccc}
\hline & \multicolumn{3}{c}{ Strongly Agree } & \multicolumn{2}{c}{ Agree } & \multicolumn{2}{c}{ Disagree } & \multicolumn{2}{c}{ Strongly Disagree } & \multicolumn{2}{c}{ Not Applicable } \\
\cline { 2 - 10 } & $\mathrm{N}$ & $\%$ & $\mathrm{~N}$ & $\%$ & $\mathrm{~N}$ & $\%$ & $\mathrm{~N}$ & $\%$ & $\mathrm{~N}$ & $\%$ \\
\hline $\begin{array}{l}\text { It was tradition in my family to } \\
\text { attend college }\end{array}$ & 45 & 16.4 & 75 & 27.4 & 96 & 35.0 & 51 & 18.6 & 7 & 2.6 \\
$\begin{array}{l}\text { My family encouraged me to } \\
\text { attend college }\end{array}$ & 180 & 66.2 & 79 & 29.0 & 13 & 4.8 & 0 & .0 & 0 & .0 \\
$\begin{array}{l}\text { My grandparents encouraged me to } \\
\text { attend college }\end{array}$ & 143 & 52.6 & 74 & 27.2 & 31 & 11.4 & 12 & 4.4 & 12 & 4.4 \\
$\begin{array}{l}\text { My high school teachers } \\
\text { encouraged me to attend college }\end{array}$ & 162 & 59.6 & 83 & 30.5 & 16 & 5.9 & 9 & 3.3 & 2 & .7 \\
\hline
\end{tabular}


A majority of the respondents $(\mathrm{N}=245,90.1 \%)$ agreed that high school teachers had encouraged them to attend college with 162 respondents (59.6\%) expressing agreement and 83 individuals (30.5\%) expressing strong agreement with the statement. Sixteen respondents (5.9\%) disagreed with the statement while nine individuals (3.3\%) expressing strong disagreement. Two individuals (.7\%) indicated that the statement did not apply to them (see Table 9).

\section{Independence and Enrollment Factors}

Three statements were presented to the respondents centering on independence and enrollment at West Virginia University. Ninety-eight respondents (36.3\%) strongly agreed with the statement that a college education would improve their feelings of selfworth while 132 individuals (48.9\%) agreed with the statement. Thirty-five respondents (13.0\%) disagreed with the statement and five individuals (1.9\%) expressed strong disagreement.

Twenty-four respondents (8.9\%) strongly agreed that attending college allowed them to delay being a grown up while 62 individuals (23.0\%) agreed with the statement. One hundred two respondents (37.8\%) disagreed with the statement and 80 individuals (29.6\%) expressed strong disagreement. Two individuals (.7\%) indicated that it did not apply to them.

Ninety-four respondents (34.6\%) strongly agreed with the statement that college was the first step in gaining person independence while 146 individuals (53.7\%) expressed agreement with the statement. Twenty-four respondents (8.8\%) disagreed with the statement and eight individuals (2.9\%) expressed strong disagreement (see Table $10)$. 
Table 10

Independence Factors Affecting Enrollment of Respondents

\begin{tabular}{|c|c|c|c|c|c|c|c|c|c|c|}
\hline & \multicolumn{2}{|c|}{ Strongly Agree } & \multicolumn{2}{|c|}{ Agree } & \multicolumn{2}{|c|}{ Disagree } & \multicolumn{2}{|c|}{ Strongly Disagree } & \multicolumn{2}{|c|}{ Not Applicable } \\
\hline & $\mathrm{N}$ & $\%$ & $\mathrm{~N}$ & $\%$ & $\mathrm{~N}$ & $\%$ & $\mathrm{~N}$ & $\%$ & $\mathrm{~N}$ & $\%$ \\
\hline $\begin{array}{l}\text { A college education would } \\
\text { improve my feelings of self worth }\end{array}$ & 98 & 36.3 & 132 & 48.9 & 35 & 13.0 & 5 & 1.9 & 0 & .0 \\
\hline $\begin{array}{l}\text { Attending college allowed me to } \\
\text { delay being a grown-up }\end{array}$ & 24 & 8.9 & 62 & 23.0 & 102 & 37.8 & 80 & 29.6 & 2 & .7 \\
\hline $\begin{array}{l}\text { College was the first step in } \\
\text { gaining personal independence }\end{array}$ & 94 & 34.6 & 146 & 53.7 & 24 & 8.8 & 8 & 2.9 & 0 & .0 \\
\hline
\end{tabular}




\section{Personal Determination Involving Enrollment}

Four statements were presented to the respondents dealing with determination and enrollment. One hundred sixty-four respondents (59.9\%) strongly agreed that they have a drive to succeed while 95 individuals (34.7\%) agreed with the statement. Ten respondents (3.6\%) disagreed with the statement and two individuals (.7\%) expressed strong disagreement. Three respondents (1.1\%) indicated that the statement did not apply to them.

Seventy-nine respondents $(28.9 \%)$ strongly agreed that they wanted to do something their parents did not have the opportunity to do while 63 individuals $(23.1 \%)$ agreed with the statement. Seventy-eight respondents $(28.6 \%)$ disagreed with the statement and 17 individuals (6.2\%) expressed strong disagreement. Thirty-six respondents indicated $(13.2 \%)$ that the statement did not apply to them.

Eighty-five respondents $(31.0 \%)$ strongly agreed that they were determined to succeed in spite of others' perceptions while 101 individuals (36.9\%) agreed with the statement. Fifty-two respondents (19.0\%) disagreed with the statement and 19 individuals (6.9\%) expressed strong disagreement. Seventeen respondents $(6.2 \%)$ indicated that the statement did not apply to them.

Forty respondents $(14.6 \%)$ strongly agreed that their dreams and hopes centered on West Virginia University while 93 individuals (33.9\%) agreed with the statement. One hundred seven respondents (39.1\%) disagreed with the statement and 23 individuals (8.4\%) expressed strong disagreement. Eleven respondents $(4.0 \%)$ indicated that the statement was not applicable to them (see Table 11). 
Table 11

Determination Factors Effect on Enrollment of Respondents

\begin{tabular}{lcccccccccc}
\hline & \multicolumn{3}{c}{ Strongly Agree } & \multicolumn{2}{c}{ Agree } & \multicolumn{2}{c}{ Disagree } & \multicolumn{2}{c}{ Strongly Disagree } & \multicolumn{2}{c}{ Not Applicable } \\
\cline { 2 - 11 } & $\mathrm{N}$ & $\%$ & $\mathrm{~N}$ & $\%$ & $\mathrm{~N}$ & $\%$ & $\mathrm{~N}$ & $\%$ & $\mathrm{~N}$ & $\%$ \\
\hline $\begin{array}{l}\text { I have a drive to succeed } \\
\text { I wanted to do something my }\end{array}$ & 164 & 59.9 & 95 & 34.7 & 10 & 3.6 & 2 & .7 & 3 & 1.1 \\
$\begin{array}{l}\text { parents did not have the } \\
\text { opportunity to do }\end{array}$ & 79 & 28.9 & 63 & 23.1 & 78 & 28.6 & 17 & 6.2 & 36 & 13.2 \\
$\begin{array}{l}\text { I was determined to succeed in } \\
\text { spite of others' perceptions }\end{array}$ & 85 & 31.0 & 101 & 36.9 & 52 & 19.0 & 19 & 6.9 & 17 & 6.2 \\
$\begin{array}{l}\text { My dreams and hopes centered on } \\
\text { WVU }\end{array}$ & 40 & 14.6 & 93 & 33.9 & 107 & 39.1 & 23 & 8.4 & 11 & 4.0 \\
\hline
\end{tabular}




\section{Financial and Enrollment Factors}

Five statements were presented to the respondents dealing with financials and enrollment factors. A majority of the respondents $(\mathrm{N}=253,93 \%)$ agreed that a college education would give them financial security with 149 respondents $(54.8 \%)$ expressing strong agreement with the statement and 104 individuals (38.2\%) expressing agreement with the statement. Fifteen respondents (5.5\%) disagreed with the statement and three individuals $(1.1 \%)$ expressing strong disagreement. One respondent $(.4 \%)$ indicated that the statement did not apply to them.

One hundred seventy-eight respondents (65.4\%) strongly agreed that a college education would give them the opportunity to make more money while 87 individuals $(32.0 \%)$ agreed with the statement. Six respondents $(2.2 \%)$ disagreed with the statement and one individual (.4\%) expressed strong disagreement.

One hundred seventy-three respondents (63.6\%) strongly agreed that a college education would allow them to support a family while 85 individuals (31.3\%) agreed with the statement. Ten respondents (3.7\%) disagreed with the statement and one individual (.4\%) expressed strong disagreement. Three individuals $(1.1 \%)$ indicated that the statement did not apply to them

Fifty-one respondents $(18.8 \%)$ strongly agreed that the current economic situation promoted their decision to attend college while 59 individuals $(21.7 \%)$ agreed with the statement. One hundred eighteen respondents (43.4\%) expressed disagreement with the statement and 31 individuals (11.4\%) expressed strong disagreement. Thirteen individuals (4.8\%) indicated that the statement did not apply to them. 
Table 12

Financials Factors Effect on Continued Enrollment at West Virginia University

\begin{tabular}{|c|c|c|c|c|c|c|c|c|c|c|}
\hline & \multicolumn{2}{|c|}{ Strongly Agree } & \multicolumn{2}{|c|}{ Agree } & \multicolumn{2}{|c|}{ Disagree } & \multicolumn{2}{|c|}{ Strongly Disagree } & \multicolumn{2}{|c|}{ Not Applicable } \\
\hline & $\mathrm{N}$ & $\%$ & $\mathrm{~N}$ & $\%$ & $\mathrm{~N}$ & $\%$ & $\mathrm{~N}$ & $\%$ & $\mathrm{~N}$ & $\%$ \\
\hline $\begin{array}{l}\text { A college education would give me } \\
\text { financial security }\end{array}$ & 149 & 54.8 & 104 & 38.2 & 15 & 5.5 & 3 & 1.1 & 1 & .4 \\
\hline $\begin{array}{l}\text { A college education would give me } \\
\text { the opportunity to make more } \\
\text { money }\end{array}$ & 178 & 65.4 & 87 & 32.0 & 6 & 2.2 & 1 & .4 & 0 & .0 \\
\hline $\begin{array}{l}\text { A college education would allow } \\
\text { me to support a family }\end{array}$ & 173 & 63.6 & 85 & 31.3 & 10 & 3.7 & 1 & .4 & 3 & 1.1 \\
\hline $\begin{array}{l}\text { The current economic situation } \\
\text { promoted my decision to attend } \\
\text { college }\end{array}$ & 51 & 18.8 & 59 & 21.7 & 118 & 43.4 & 31 & 11.4 & 13 & 4.8 \\
\hline $\begin{array}{l}\text { Scholarships motivated me to } \\
\text { attend WVU }\end{array}$ & 73 & 26.8 & 57 & 21.0 & 91 & 33.5 & 32 & 11.8 & 19 & 7.0 \\
\hline
\end{tabular}


Seventy-three respondents (26.8\%) strongly agreed that scholarships motivated them to attend West Virginia University while 57 individuals (21.0\%) expressed agreement with the statement. Ninety-one individuals (33.5\%) expressed disagreement with the statement and thirty-two individuals (11.8\%) expressed strong disagreement. Nineteen individuals (7.0\%) indicated that the statement did not apply to them (see Table 12).

\section{Factors that Kept Respondents Enrolled at WVU: Determination}

The respondents were asked a number of questions on their opinions about factors that kept them enrolled at West Virginia University. The questions were then grouped into seven different categories. The first grouping dealt with the students' determination to stay. A majority of the respondents $(\mathrm{N}=256,94.8 \%)$ agreed that their personal determination or motivation was a factor with 127 respondents (47.0\%) expressing strong agreement and 129 individuals (47.8\%) expressing agreement with the statement. Ten respondents (3.7\%) disagreed with the statement while one individual (.4\%) expressed strong disagreement. Three individuals (1.1\%) indicated that the statement did not apply to them.

Ten respondents (3.7\%) strongly agreed with the statement that they continued enrollment at West Virginia University because they feared change while 55 individuals (20.4\%) expressed agreement with the statement. One hundred forty-six respondents (54.1\%) disagreed with the statement while 57 individuals (21.1\%) expressed strong disagreement. Two individuals (.7\%) indicated that the statement did not apply to them. 
Table 13

Determination to Stay at WVU

\begin{tabular}{|c|c|c|c|c|c|c|c|c|c|c|}
\hline & \multicolumn{2}{|c|}{ Strongly Agree } & \multicolumn{2}{|c|}{ Agree } & \multicolumn{2}{|c|}{ Disagree } & \multicolumn{2}{|c|}{ Strongly Disagree } & \multicolumn{2}{|c|}{ Not Applicable } \\
\hline & $\mathrm{N}$ & $\%$ & $\mathrm{~N}$ & $\%$ & $\mathrm{~N}$ & $\%$ & $\mathrm{~N}$ & $\%$ & $\mathrm{~N}$ & $\%$ \\
\hline Personal determination-motivation & 127 & 47.0 & 129 & 47.8 & 10 & 3.7 & 1 & .4 & 3 & 1.1 \\
\hline I fear change & 10 & 3.7 & 55 & 20.4 & 146 & 54.1 & 57 & 21.1 & 2 & .7 \\
\hline I don't want to fail & 162 & 60.4 & 88 & 32.8 & 12 & 4.5 & 5 & 1.9 & 1 & .4 \\
\hline $\begin{array}{l}\text { Without college, I would have } \\
\text { nothing to do with my life }\end{array}$ & 35 & 13.0 & 61 & 22.6 & 134 & 49.6 & 37 & 13.7 & 3 & 1.1 \\
\hline
\end{tabular}


One hundred sixty-two respondents (60.4\%) strongly agreed with the statement that they continued enrollment at West Virginia University because they do not want to fail while 88 individuals (32.8\%) agreed with the statement. Twelve respondents (4.5\%) disagreed with the statement and five individuals (1.9\%) expressed strong disagreement. One individual (.4\%) indicated that the statement was not applicable of them.

Thirty-five respondents (13.0\%) strongly agreed with the statement that continued enrollment at West Virginia University because without college they would have nothing to do with their lives while 61 individuals $(22.6 \%)$ strongly agreed with that statement. One hundred thirty-four respondents (49.6\%) disagreed with the statement and 37 individuals (13.7\%) expressed strong disagreement. Three individuals indicated (1.1\%) that the statement did not apply to them (see Table 13).

\section{Educational Factors Affecting Continued Enrollment at WVU}

Five statements were presented to the respondents concerning education. A majority of the respondents $(\mathrm{N}=260,96.3 \%)$ agreed with the statement that career goals were important to them to stay at West Virginia University with 166 respondents (61.5\%) expressing strong agreement and 94 individuals expressing agreement with the statement. Five individuals (1.9\%) disagreed with the statement while one respondent (.4\%) expressed strong disagreement. Four individuals (1.5\%) indicated that the statement was not applicable to them. 
Table 14

Educational Reasons to Stay at WVU

\begin{tabular}{|c|c|c|c|c|c|c|c|c|c|c|}
\hline & \multicolumn{2}{|c|}{ Strongly Agree } & \multicolumn{2}{|c|}{ Agree } & \multicolumn{2}{|c|}{ Disagree } & \multicolumn{2}{|c|}{ Strongly Disagree } & \multicolumn{2}{|c|}{ Not Applicable } \\
\hline & $\mathrm{N}$ & $\%$ & $\mathrm{~N}$ & $\%$ & $\mathrm{~N}$ & $\%$ & $\mathrm{~N}$ & $\%$ & $\mathrm{~N}$ & $\%$ \\
\hline My career goal(s) & 166 & 61.5 & 94 & 34.8 & 5 & 1.9 & 1 & .4 & 4 & 1.5 \\
\hline $\begin{array}{l}\text { Employment opportunities after } \\
\text { graduation }\end{array}$ & 151 & 56.6 & 109 & 40.8 & 1 & .4 & 3 & 1.1 & 3 & 1.1 \\
\hline $\begin{array}{l}\text { The opportunity to learn-expand } \\
\text { my knowledge }\end{array}$ & 152 & 56.7 & 112 & 41.8 & 3 & 1.1 & 1 & .4 & 0 & .0 \\
\hline $\begin{array}{l}\text { Courses in my major are very } \\
\text { entertaining }\end{array}$ & 88 & 32.6 & 144 & 53.3 & 29 & 10.7 & 8 & 3.0 & 1 & .4 \\
\hline $\begin{array}{l}\text { The availability of one-on-one help } \\
\text { in the classroom }\end{array}$ & 32 & 11.9 & 119 & 44.1 & 91 & 33.7 & 21 & 7.8 & 7 & 2.6 \\
\hline
\end{tabular}


One hundred fifty-one respondents (56.6\%) strongly agreed with the statement that the employment opportunities after graduation were a reason to stay at WVU with 109 individuals (40.8\%) expressing agreement with the statement. One respondent (.4\%) disagreed with the statement and three individuals (1.1\%) expressed strong disagreement. Three respondents (1.1\%) indicated that the statement was not applicable to them.

A majority of the respondents $(\mathrm{N}=264,98.5 \%)$ agreed that the opportunity to learn or expand their knowledge was a reason to stay at WVU with 152 respondents (56.7\%) strongly agreeing with the statement and 112 individuals (41.8\%) expressing agreement. Three respondents (1.1\%) disagreed with the statement and one individual (.4\%) expressed strong disagreement.

Eighty-eight individuals (32.6\%) strong agreed that they remained at West Virginia University because courses in their major were very entertaining while 144 respondents (53.3\%) expressed agreement with the statement. Twenty-nine individuals (10.7\%) disagreed with the statement and eight individuals (3.0\%) expressed strong disagreement. One individual (.4\%) indicated that the statement did not apply to them.

Thirty-two respondents (11.9\%) strongly agreed with the statement that the availability of one-on-one help in the classroom was a reason for them to stay at WVU while 119 individuals (44.1\%) agreed with the statement. Ninety-one respondents (33.7\%) disagreed with the statement and 21 individuals (7.8\%) expressed strong disagreement. Seven respondents $(2.6 \%)$ indicated that the statement did not apply to them (see Table 14). 


\section{Encouragement to Stay Enrolled at WVU}

Five statements were presented to the respondents on encouragements they received to stay in college. Sixty-two respondents $(23.0 \%)$ strongly agreed that encouragement came from their friends while 145 individuals $(53.9 \%)$ expressed agreement with the statement. Fifty-one respondents (19.0\%) disagreed with the statement and seven individuals (2.6\%) expressed strong disagreement. Four respondents $(1.5 \%)$ indicated that the statement was not applicable to them.

One hundred nineteen respondents (44.2\%) agreed that they stayed at West Virginia University to make their parents proud while 125 individuals (46.5\%) expressed agreement with the statement. Twenty-one respondents $(7.8 \%)$ disagreed with the statement and two individuals (.7\%) expressed strong disagreement. Two individuals $(.7 \%)$ indicated that the statement was not applicable to them.

Forty-four respondents (16.4\%) strongly agreed that their parents' insistence kept them at West Virginia University while 103 individuals (38.4\%) expressed agreement with the statement. Eighty-nine respondents (33.2\%) disagreed with the statement and 24 individuals (9.0\%) expressed strong disagreement. Eight individuals (3.0\%) indicated that the statement did not apply to them.

Thirty-four respondents (12.7\%) strongly agreed that significant others' encouragement was a factor in staying at West Virginia University while 77 individuals (28.8\%) expressed agreement with the statement. Seventy-one respondents $(26.6 \%)$ disagreed with the statement and 29 individuals (10.9\%) expressed strong disagreement. Fifty-six respondents $(21.0 \%)$ indicated that the statement was not applicable to them (see Table 15). 
Table 15

Encouragement Factors that Kept Students Enrolled at West Virginia University

\begin{tabular}{lcccccccccc}
\hline & \multicolumn{2}{c}{ Strongly Agree } & \multicolumn{2}{c}{ Agree } & \multicolumn{2}{c}{ Disagree } & \multicolumn{2}{c}{ Strongly Disagree } & \multicolumn{2}{c}{ Not Applicable } \\
\cline { 2 - 11 } & $\mathrm{N}$ & $\%$ & $\mathrm{~N}$ & $\%$ & $\mathrm{~N}$ & $\%$ & $\mathrm{~N}$ & $\%$ & $\mathrm{~N}$ & $\%$ \\
\hline Encouragement from my friends & 62 & 23.0 & 145 & 53.9 & 51 & 19.0 & 7 & 2.6 & 4 & 1.5 \\
To make my parents proud & 119 & 44.2 & 125 & 46.5 & 21 & 7.8 & 2 & .7 & 2 & .7 \\
$\begin{array}{l}\text { My parents' insistence } \\
\text { My significant other's }\end{array}$ & 44 & 16.4 & 103 & 38.4 & 89 & 33.2 & 24 & 9.0 & 8 & 3.0 \\
encouragement" & 34 & 12.7 & 77 & 28.8 & 71 & 26.6 & 29 & 10.9 & 56 & 21.0 \\
My family's encouragement & 101 & 37.7 & 137 & 51.1 & 23 & 8.6 & 5 & 1.9 & 2 & .7 \\
\hline
\end{tabular}


A majority of the respondents $(\mathrm{N}=238,88.8 \%)$ agreed that they had family encouragement to stay at West Virginia University with 101 respondents (37.7\%) strongly agreeing with the statement and 137 individuals (51.1\%) expressing agreement with the statement. Twenty-three respondents $(8.6 \%)$ disagreed with the statement and five individuals (1.9\%) expressed strong disagreement. Two individuals (.7\%) indicated that the statement did not apply to them (see Table 15).

\section{West Virginia University Resources}

Five statements were presented on resources at West Virginia University. Thirtytwo respondents $(12.0 \%)$ strongly agreed with the statement that resources available to students were a reason to stay at West Virginia University with 137 individuals $(51.3 \%)$ expressing agreement with the statement. Seventy-nine individuals (29.6\%) disagreed with the statement and 13 respondents (4.9\%) expressed strong disagreement. Six individuals (2.2\%) indicated that the statement was not applicable to them. 
Table 16

Resources Available to Students as a Factor to Stay at West Virginia University

\begin{tabular}{|c|c|c|c|c|c|c|c|c|c|c|}
\hline & \multicolumn{2}{|c|}{ Strongly Agree } & \multicolumn{2}{|c|}{ Agree } & \multicolumn{2}{|c|}{ Disagree } & \multicolumn{2}{|c|}{ Strongly Disagree } & \multicolumn{2}{|c|}{ Not Applicable } \\
\hline & $\mathrm{N}$ & $\%$ & $\mathrm{~N}$ & $\%$ & $\mathrm{~N}$ & $\%$ & $\mathrm{~N}$ & $\%$ & $\mathrm{~N}$ & $\%$ \\
\hline $\begin{array}{l}\text { The resources available to students } \\
\text { (computers, tutors, etc) }\end{array}$ & 32 & 12.0 & 137 & 51.3 & 79 & 29.6 & 13 & 4.9 & 6 & 2.2 \\
\hline The size of WVU & 61 & 22.8 & 134 & 50.2 & 58 & 21.7 & 11 & 4.1 & 3 & 1.1 \\
\hline The facilities available to students & 69 & 25.7 & 153 & 57.1 & 38 & 14.2 & 4 & 1.5 & 4 & 1.5 \\
\hline $\begin{array}{l}\text { WVU has knowledgeable faculty- } \\
\text { professors }\end{array}$ & 62 & 23.3 & 177 & 66.5 & 22 & 8.3 & 3 & 1.1 & 2 & .8 \\
\hline Friendly and personable professors & 65 & 24.3 & 175 & 65.5 & 20 & 7.5 & 3 & 1.1 & 4 & 1.5 \\
\hline
\end{tabular}


Sixty-one respondents (22.8\%) strongly agreed with the statement that the size of West Virginia University was a factor in their staying while 134 individuals (50.2\%) expressed agreement with the statement. Fifty-eight respondents (21.7\%) disagreed with the statement and 11 individuals (4.1\%) expressed strong disagreement. Three respondents (1.1\%) indicated that the statement did not apply to them.

Sixty-nine respondents $(25.7 \%)$ strongly agreed that the facilities available to the students were an important aspect to staying at West Virginia University while 153 individuals (57.1\%) expressed agreement with the statement. Thirty-eight respondents (14.2\%) disagreed with the statement and four individuals (1.5\%) expressed strong disagreement. Four individuals $(1.5 \%)$ indicated that the statement was not applicable to them (see Table 17).

Sixty-two respondents (23.3\%) strongly agreed with the statement that they stayed at WVU because of knowledgeable faculty-professors while 177 individuals (66.5\%) expressed agreement with the statement. Twenty-two respondents $(8.3 \%)$ disagreed with the statement and three individuals (1.1\%) expressed strong disagreement. Two individuals (.8\%) indicated the statement was not applicable to them.

Sixty-five respondents (24.3\%) strongly agreed that friendly and personable professors were a reason to stay at West Virginia University while 175 individuals (65.5\%) expressed agreement with the statement. Twenty respondents (7.5\%) disagreed with the statement and three individuals (1.1\%) expressed strong disagreement. Four individuals (1.5\%) indicated that the statement was not applicable (see Table 16). 


\section{Financial Reasons to Stay at WVU}

Four statements were presented to the respondents on financial situations that affected their decision to stay. Forty-three respondents (16.0\%) strongly agreed with the statement that the current economic situation affected their staying at West Virginia University while 98 individuals (36.6\%) expressed agreement with the statement.

Fifty-two respondents (19.4\%) strongly agreed with the statement that the availability of financial aid was a factor in their staying at West Virginia University while 86 individuals (32.1\%) expressed strong agreement. Eighty-one respondents $(30.2 \%)$ disagreed with the statement and 25 individuals (9.3\%) expressed strong disagreement. Twenty-four respondents $(9.0 \%)$ indicated that the statement was not applicable to them (see Table 17).

A majority of the respondents $(\mathrm{N}=159,59.1 \%)$ agreed with the statement that parental funding was an factor to stay at West Virginia University with 51 respondents (19.0\%) expressing strong agreement while 108 individuals (40.1\%) expressed agreement with the statement. Sixty-nine respondents $(25.7 \%)$ disagreed with the statements and 30 individuals (11.2\%) expressed strong disagreement. Eleven individuals (7.1\%) indicated that the statement was not applicable. 
Table 17

Financial Reasons to Remain at WVU

\begin{tabular}{lccccccccccc}
\hline & \multicolumn{2}{c}{ Strongly Agree } & \multicolumn{2}{c}{ Agree } & \multicolumn{2}{c}{ Disagree } & \multicolumn{2}{c}{ Strongly Disagree } & Not Applicable \\
\cline { 2 - 10 } & $\mathrm{N}$ & $\%$ & $\mathrm{~N}$ & $\%$ & $\mathrm{~N}$ & $\%$ & $\mathrm{~N}$ & $\%$ & $\mathrm{~N}$ & $\%$ \\
\hline The current economic situation & 43 & 16.0 & 98 & 36.6 & 100 & 37.3 & 17 & 6.3 & 10 & 3.7 \\
The availability of financial aid & 52 & 19.4 & 86 & 32.1 & 81 & 30.2 & 25 & 9.3 & 24 & 9.0 \\
Parental funding & 51 & 19.0 & 108 & 40.1 & 69 & 25.7 & 30 & 11.2 & 11 & 4.1 \\
The availability of scholarships & 62 & 23.0 & 94 & 34.9 & 67 & 24.9 & 27 & 10.0 & 19 & 7.1 \\
\hline
\end{tabular}


Sixty-two respondents $(23.0 \%)$ strongly agreed with the statement that the availability of scholarship was an important aspect in staying at West Virginia University while 94 individuals (34.9\%) expressed agreement with the statement. Sixty-seven respondents (24.9\%) disagreed with the statement and 27 individuals (10.0\%) expressed strong disagreement. Nineteen individuals (7.1\%) indicated that the statement did not apply to them (see Table 17).

\section{Location of WVU as a Factor Concerning Continual Enrollment}

Two statements were presented to the respondents concerning the location at West Virginia University as a reason to remain at the University. A majority of the respondents $(\mathrm{N}=221,82.4 \%)$ agreed with the statement that the location of West Virginia University was an important aspect to their decision to stay at WVU with 88 respondents (32.8\%) expressing strong agreement with the statement and 133 (49.6\%) expressing agreement. Thirty-six respondents (13.4\%) disagreed with the statement and nine individuals (3.4\%) expressed strong disagreement. Two individuals (.7\%) indicated that the statement was not applicable to them.

Fourteen individuals (5.3\%) strongly agreed that they stayed at West Virginia University because their major was not offered in their home state and 19 respondents (7.1\%) expressed agreement with the statement. One hundred six respondents (39.8\%) disagreed with the statement and 52 individuals (19.5\%) expressed strong disagreement. Seventy-five respondents (28.2\%) indicated that the statement did not apply to them (see Table 18). 
Table 18

Location of WVU as a Factor Concerning Continual Enrollment

\begin{tabular}{|c|c|c|c|c|c|c|c|c|c|c|}
\hline & \multicolumn{2}{|c|}{ Strongly Agree } & \multicolumn{2}{|c|}{ Agree } & \multicolumn{2}{|c|}{ Disagree } & \multicolumn{2}{|c|}{ Strongly Disagree } & \multicolumn{2}{|c|}{ Not Applicable } \\
\hline & $\mathrm{N}$ & $\%$ & $\mathrm{~N}$ & $\%$ & $\mathrm{~N}$ & $\%$ & $\mathrm{~N}$ & $\%$ & $\mathrm{~N}$ & $\%$ \\
\hline The location of WVU & 88 & 32.8 & 133 & 49.6 & 36 & 13.4 & 9 & 3.4 & 2 & .7 \\
\hline $\begin{array}{l}\text { My major is not available in my } \\
\text { home state }\end{array}$ & 14 & 5.3 & 19 & 7.1 & 106 & 39.8 & 52 & 19.5 & 75 & 28.2 \\
\hline
\end{tabular}




\section{Social Reasons to Stay at WVU}

Seven statements were presented to the respondents on social situations and the atmosphere as reasons to stay at West Virginia University. Eighty-five respondents $(32.1 \%)$ strongly agreed with the statement that they stayed at West Virginia University because it offered many opportunities for students to become involved while 148 individuals $(55.8 \%)$ expressed agreement with the statement. Twenty-seven individuals $(10.2 \%)$ disagreed with the statement and one respondent (.4\%) expressed strong agreement. Four individuals $(1.5 \%)$ indicated that the statement was not applicable to them.

Sixty respondents $(22.4 \%)$ strongly agreed with the statement that they stayed at West Virginia University because their friends were here while 122 individuals (45.5\%) expressed agreement with the statement. Sixty individuals (22.4\%) disagreed with the statement and 17 respondents $(6.3 \%)$ expressed strong disagreement. Nine individuals $(3.4 \%)$ indicated that the statement did not apply to them.

Eighty-four respondents (31.5\%) strongly agreed with the statement that athletic events were a reason to stay at West Virginia University while 114 individuals $(42.7 \%)$ agreed with the statement. Forty-one individuals (15.4\%) disagreed with the statement and 21 respondents $(7.9 \%)$ expressed strong disagreement. Seven individuals $(2.6 \%)$ indicated that the statement did not apply to them. 
Table 19

Social/Atmosphere as a Factor to Remain at West Virginia University

\begin{tabular}{lcccccccccc}
\hline & \multicolumn{2}{c}{ Strongly Agree } & \multicolumn{2}{c}{ Agree } & \multicolumn{2}{c}{ Disagree } & \multicolumn{2}{c}{ Strongly Disagree } & Not Applicable \\
\cline { 2 - 8 } & $\mathrm{N}$ & $\%$ & $\mathrm{~N}$ & $\%$ & $\mathrm{~N}$ & $\%$ & $\mathrm{~N}$ & $\%$ & $\mathrm{~N}$ & $\%$ \\
\hline $\begin{array}{l}\text { WVU offers many opportunities } \\
\text { for students to become involved }\end{array}$ & 85 & 32.1 & 148 & 55.8 & 27 & 10.2 & 1 & .4 & 4 & 1.5 \\
My friends are here & 60 & 22.4 & 122 & 45.5 & 60 & 22.4 & 17 & 6.3 & 9 & 3.4 \\
Athletic events & 84 & 31.5 & 114 & 42.7 & 41 & 15.4 & 21 & 7.9 & 7 & 2.6 \\
I enjoy the WVU atmosphere & 114 & 42.7 & 126 & 47.2 & 21 & 7.9 & 3 & 1.1 & 3 \\
I feel at home at WVU & 101 & 37.8 & 122 & 45.7 & 35 & 13.1 & 6 & 2.2 & 3 \\
Parties & 50 & 18.8 & 103 & 38.7 & 62 & 23.3 & 45 & 16.9 & 6 \\
Social life & 72 & 27.0 & 148 & 55.4 & 35 & 13.1 & 9 & 3.4 & 3 \\
\hline
\end{tabular}


A majority of the respondents $(\mathrm{N}=240,89.9 \%)$ agreed that they stayed at West Virginia University because they enjoyed the WVU atmosphere with 114 respondents strongly agreeing with the statement and 126 individuals (47.2\%) expressing agreement. Twenty-one respondents (7.9\%) disagreed with the statement and three individuals (1.1\%) expressed strong disagreement. Three respondents (1.1\%) indicated that the statement was not applicable to them.

One hundred one respondents (37.8\%) strongly agreed with the statement that they stayed at West Virginia University because they felt at home at WVU while 122 individuals (45.7\%) expressed agreement with the statement. Thirty-five individuals (13.1\%) indicated that they disagreed with the statement and six individuals (2.2\%) expressed strong disagreement. Three respondents $(1.1 \%)$ indicated that the statement did not apply to them.

A majority of the respondents $(\mathrm{N}=153,57.5 \%)$ agreed that parties were a reason to stay at WVU with 50 individuals (18.8\%) strongly agreeing with the statement and 103 respondents (38.7\%) expressed agreement with the statement. Sixty-two individuals (23.3\%) disagreed with the statement and 45 respondents (16.9\%) expressed strong disagreement. Six individuals (2.3\%) indicated that the statement was not applicable to them.

Seventy-two individuals (27.0\%) strongly agreed that social life was a factor when deciding to stay at WVU while 148 respondents (55.4\%) expressed agreement with the statement. Thirty-five respondents (13.1\%) disagreed with the statement and nine individuals (3.4\%) expressed strong disagreement. Three respondents (1.1\%) indicated that the statement was not applicable to them (see Table 19). 


\section{Career Decisions Concerning Possible Reasons to Leave WVU}

Respondents were asked if they have ever considered leaving West Virginia University. If they had considered leaving, they were to respond to a series of statement on factors affecting their decision to consider leaving the University. Those statements were further broken down into eight different categories. There were three statements that on career decisions. Five respondents (5.7\%) strongly agreed they considered leaving West Virginia University because their classes did not pertain to their interests while 20 individuals $(22.7 \%)$ expressed agreement with the statement. Forty-three individuals (48.9\%) disagreed with the statement and 18 respondents $(20.5 \%)$ expressed strong disagreement. Two respondents $(2.3 \%)$ indicated that the statement did not apply to them.

Six individuals (6.8\%) agreed they considered leaving West Virginia University because they did not need the degree. Forty-eight respondents $(54.5 \%)$ disagreed with the statement and 32 individuals (36.4\%) expressed strong agreement. Two individuals $(2.3 \%)$ indicated that the statement did not apply to them.

Three respondents $(3.4 \%)$ strongly agreed with the statement that they considered leaving West Virginia University because they had limited career options while 13 individuals (14.8\%) expressed agreement with the statement. Forty-seven individuals (53.4\%) disagreed with the statement and 22 respondents $(25.0 \%)$ expressed strong disagreement. Three individuals (3.4\%) indicated that the statement did not apply to them (see Table 20). 
Table 20

Career Decisions as a Factor to Leave West Virginia University

\begin{tabular}{lcccccccccc}
\hline & \multicolumn{2}{c}{ Strongly Agree } & \multicolumn{2}{c}{ Agree } & & Disagree & \multicolumn{2}{c}{ Strongly Disagree } & Not Applicable \\
\cline { 2 - 9 } & $\mathrm{N}$ & $\%$ & $\mathrm{~N}$ & $\%$ & $\mathrm{~N}$ & $\%$ & $\mathrm{~N}$ & $\%$ & $\mathrm{~N}$ & $\%$ \\
\hline $\begin{array}{l}\text { Classes did not pertain to my } \\
\text { interests }\end{array}$ & 5 & 5.7 & 20 & 22.7 & 43 & 48.9 & 18 & 20.5 & 2 & 2.3 \\
I didn't need the degree & 0 & .0 & 6 & 6.8 & 48 & 54.5 & 32 & 36.4 & 2 & 2.3 \\
Limited career options & 3 & 3.4 & 13 & 14.8 & 47 & 53.4 & 22 & 25.0 & 3 & 3.4 \\
\hline
\end{tabular}

Table 21

College Atmosphere as a Factor to Leave West Virginia University

\begin{tabular}{lccccccccccc}
\hline & \multicolumn{2}{c}{ Strongly Agree } & \multicolumn{2}{c}{ Agree } & & \multicolumn{2}{c}{ Disagree } & \multicolumn{2}{c}{ Strongly Disagree } & Not Applicable \\
\cline { 2 - 10 } & $\mathrm{N}$ & $\%$ & $\mathrm{~N}$ & $\%$ & $\mathrm{~N}$ & $\%$ & $\mathrm{~N}$ & $\%$ & $\mathrm{~N}$ & $\%$ \\
\hline Roommates & 11 & 12.5 & 24 & 27.3 & 32 & 36.4 & 18 & 20.5 & 3 & 3.4 \\
Rude students & 11 & 12.6 & 32 & 36.8 & 26 & 29.9 & 16 & 18.4 & 2 & 2.3 \\
\hline
\end{tabular}


Eleven respondents (12.5\%) strongly agreed they considered leaving West Virginia University because of roommates while 24 individuals (27.3\%) expressed agreement with the statement. Thirty-two individuals (36.4\%) disagreed with the statement and 18 respondents (20.5\%) expressed strong disagreement. Three individuals (3.4\%) indicated that the statement did not apply to them.

Eleven respondents (12.6\%) strongly agreed with the statement that rude students had something to do with their consideration to leave West Virginia University while 32 respondents (36.8\%) agreed with the statement. Twenty-six respondents $(29.9 \%)$ disagreed with the statement and 16 individuals (18.4\%) expressed strong disagreement. Two individuals (2.3\%) indicated that the statement did not apply to them (see Table 21).

\section{Difficulties and Grades Concerning Factors That May Cause Students to Leave}

Four respondents (4.5\%) strongly agreed with the statement that their inability to go to school and work full time was a factor for considerations to leave the University while 16 respondents (18.2\%) expressed agreement with the statement. Thirty-eight individuals (43.2\%) disagreed with the statement and 17 respondents (19.3\%) expressed strong disagreement. Thirteen individuals $(14.8 \%)$ indicated that the statement was not applicable to them.

Three individuals (3.4\%) strongly agreed they considered leaving West Virginia University because college required too much studying while 14 respondents (15.9\%) expressed agreement with the statement. Forty-two individuals (47.7\%) disagreed with the statement and 26 respondents (29.5\%) expressed strong disagreement. Three individuals (3.4\%) indicated that the statement was not applicable to them. 
Three individuals (3.4\%) strongly agreed they considered leaving West Virginia University because the school work was too hard while 11 respondents (12.6\%) expressed agreement with the statement. Forty-six individuals (52.9\%) disagreed with the statement and 25 respondents (28.7\%) expressed strong disagreement. Two individuals (2.3\%) indicated that the statement was not applicable to them (see Table 22).

Four individuals (4.7\%) strongly agreed that poor grades were a consideration to leave West Virginia University while 12 respondents (14.0\%) expressed agreement with the statement. Twenty-eight respondents (32.6\%) disagreed with the statement and 37 individuals (43.0\%) expressed strong disagreement. Five individuals (5.8\%) indicated that the statement was not applicable to them.

Seven individuals (8.0\%) strongly agreed they considered leaving West Virginia University because they felt like they weren't making any progress while 22 respondents (25.0\%) expressed agreement with the statement. Twenty-nine individuals (33.0\%) disagreed with the statement and 25 respondents (28.4\%) expressed strong disagreement. Five individuals (5.7\%) indicated that the statement did not apply to them (see Table 22).

\section{Discouragement as a Factor to Leave West Virginia University}

Ten respondents (11.4\%) strongly agreed they considered leaving West Virginia University because they became discouraged while 42 individuals (47.7\%) expressed agreement with statement. Twenty-four respondents (27.3\%) disagreed with the statement and 10 individuals (11.4\%) expressed strong disagreement. Two individuals $(2.3 \%)$ indicated that the statement was not applicable to them. 
Table 22

Difficulties/Grades as a Factor to Leave West Virginia University

\begin{tabular}{lcccccccccc}
\hline & \multicolumn{2}{c}{ Strongly Agree } & \multicolumn{2}{c}{ Agree } & & Disagree & \multicolumn{2}{c}{ Strongly Disagree } & Not Applicable \\
\cline { 2 - 9 } & $\mathrm{N}$ & $\%$ & $\mathrm{~N}$ & $\%$ & $\mathrm{~N}$ & $\%$ & $\mathrm{~N}$ & $\%$ & $\mathrm{~N}$ & $\%$ \\
\hline $\begin{array}{l}\text { Inability to go to school and work } \\
\text { full-time }\end{array}$ & 4 & 4.5 & 16 & 18.2 & 38 & 43.2 & 17 & 19.3 & 13 & 14.8 \\
Required too much studying & 3 & 3.4 & 14 & 15.9 & 42 & 47.7 & 26 & 29.5 & 3 & 3.4 \\
School work was too hard & 3 & 3.4 & 11 & 12.6 & 46 & 52.9 & 25 & 28.7 & 2 & 2.3 \\
Poor grades & 4 & 4.7 & 12 & 14.0 & 28 & 32.6 & 37 & 43.0 & 5 & 5.8 \\
I felt like I wasn't making progress & 7 & 8.0 & 22 & 25.0 & 29 & 33.0 & 25 & 28.4 & 5 & 5.7 \\
\hline
\end{tabular}


Fourteen individuals (15.9\%) strongly agreed they considered leaving West Virginia University because they felt burned out while 33 respondents (37.5\%) expressed agreement with the statement. Twenty-four individuals (27.3\%) disagreed with the statement and 13 respondents (14.8\%) expressed strong disagreement. Four individuals $(4.5 \%)$ indicated that the statement did not apply to them.

Ten respondents (11.4\%) strongly agreed they considered leaving West Virginia University because they had felt overwhelmed while 42 individuals (47.7\%) expressed agreement the statement. Twenty-three individuals (26.1\%) disagreed with the statement and 12 respondents (13.6\%) expressed strong disagreement. Three individuals (3.4\%) indicated that the statement did not apply to them (see Table 23).

\section{Family Issues Concerning Considerations to Leave WVU}

Six individuals (6.8\%) strongly agreed with the statement that family commitments were a part of their consideration to leave the University while 15 respondents $(17.0 \%)$ expressed agreement with the statement. Forty-three individuals (48.9\%) disagreed with the statement and 16 individuals (18.2\%) expressed strong disagreement. Eight individuals (9.1\%) indicated that the statement did not apply to them.

Ten respondents (11.4\%) strongly agreed with the statement that they considered leaving West Virginia University because family issues created stress while 26 individuals (29.5\%) expressed agreement with the statement. Thirty-one individuals disagreed with the statement and 18 respondents (20.5\%) expressed strong disagreement. Three individuals (3.4\%) indicated that the statement was not applicable to them. 
Table 23

Discouragement as a Factor to Leave West Virginia University

\begin{tabular}{lcccccccccc}
\hline & \multicolumn{2}{c}{ Strongly Agree } & \multicolumn{2}{c}{ Agree } & & \multicolumn{2}{c}{ Disagree } & \multicolumn{2}{c}{ Strongly Disagree } & Not Applicable \\
\cline { 2 - 9 } & $\mathrm{N}$ & $\%$ & $\mathrm{~N}$ & $\%$ & $\mathrm{~N}$ & $\%$ & $\mathrm{~N}$ & $\%$ & $\mathrm{~N}$ & $\%$ \\
\hline I became discouraged & 10 & 11.4 & 42 & 47.7 & 24 & 27.3 & 10 & 11.4 & 2 & 2.3 \\
I was burnt out & 14 & 15.9 & 33 & 37.5 & 24 & 27.3 & 13 & 14.8 & 4 & 4.5 \\
I was overwhelmed & 10 & 11.4 & 40 & 45.5 & 23 & 26.1 & 12 & 13.6 & 3 & 3.4 \\
\hline
\end{tabular}

Table 24

Family as a Factor to Leave West Virginia University

\begin{tabular}{lcccccccccc}
\hline & \multicolumn{2}{c}{ Strongly Agree } & \multicolumn{2}{c}{ Agree } & \multicolumn{2}{c}{ Disagree } & \multicolumn{2}{c}{ Strongly Disagree } & Not Applicable \\
\cline { 2 - 9 } & $\mathrm{N}$ & $\%$ & $\mathrm{~N}$ & $\%$ & $\mathrm{~N}$ & $\%$ & $\mathrm{~N}$ & $\%$ & $\mathrm{~N}$ & $\%$ \\
\hline Family commitments & 6 & 6.8 & 15 & 17.0 & 43 & 48.9 & 16 & 18.2 & 8 & 9.1 \\
$\begin{array}{l}\text { Family issues that created stress } \\
\begin{array}{l}\text { I didn't like being away from my } \\
\text { family }\end{array}\end{array}$ & 10 & 11.4 & 26 & 29.5 & 31 & 35.2 & 18 & 20.5 & 3 & 3.4 \\
\hline
\end{tabular}


Fourteen individuals (15.9\%) strongly agreed with the statement that they considered leaving West Virginia University because they did not like being away from their families while 25 respondents (28.4\%) expressed agreement with the statement. Thirty-four respondents (38.6\%) disagreed with the statement and 13 individuals (14.8\%) expressed strong disagreement. Two individuals (2.3\%) indicated that they statement did not apply to them (see Table 24).

\section{Economic Reasons to Consider Leaving WVU}

Ten individuals (11.4\%) strongly agreed with the statement that the current economy was a reason they considered leaving the University while 20 individuals (22.7\%) expressed agreement with the statement. Thirty-five individuals (39.8\%) disagreed with the statement and 20 respondents (22.7\%) expressed strong disagreement. Three individuals (3.4\%) indicated that the statement did not apply to them.

Eleven respondents (12.5\%) strongly agreed with the statement that family finances were an issue in their consideration to leave West Virginia University while 21 individuals (23.9\%) expressed agreement with the statement. Thirty-four respondents (38.6\%) disagreed with the statement and 19 individuals (21.6\%) expressed strong disagreement. Three individuals (3.4\%) indicated that the statement did not apply to them. 
Table 25

Financials Factors Affecting Consideration to Leave West Virginia University

\begin{tabular}{lcccccccccc}
\hline & \multicolumn{2}{c}{ Strongly Agree } & \multicolumn{2}{c}{ Agree } & \multicolumn{2}{c}{ Disagree } & \multicolumn{2}{c}{ Strongly Disagree } & \multicolumn{2}{c}{ Not Applicable } \\
\cline { 2 - 9 } & $\mathrm{N}$ & $\%$ & $\mathrm{~N}$ & $\%$ & $\mathrm{~N}$ & $\%$ & $\mathrm{~N}$ & $\%$ & $\mathrm{~N}$ & $\%$ \\
\hline Current economy & 10 & 11.4 & 20 & 22.7 & 35 & 39.8 & 20 & 22.7 & 3 & 3.4 \\
Family finances & 11 & 12.5 & 21 & 23.9 & 34 & 38.6 & 19 & 21.6 & 3 & 3.4 \\
Increasing cost of tuition & 16 & 18.2 & 21 & 23.9 & 29 & 33.0 & 19 & 21.6 & 3 & 3.4 \\
\hline
\end{tabular}


Sixteen individuals (18.2\%) strongly agreed with the statement that the increasing cost of tuition was a factor in their consideration to leave West Virginia University while 21 respondents (23.9\%) expressed agreement with the statement. Twenty-nine individuals (33.0\%) disagreed with the statement and 19 respondents (21.6\%) expressed strong disagreement. Three individuals (3.4\%) indicated that the statement did not apply to them (see Table 25).

\section{Homesick or Personal Reasons for Considerations to Leave WVU}

Sixteen respondents (18.2\%) strongly agreed that they considered leaving West Virginia University because they felt alone while 31 individuals (35.2\%) expressed agreement with the statement. Twenty-seven individuals (30.7\%) disagreed with the statement and 13 individuals (14.8\%) expressed strong disagreement. One individual $(1.1 \%)$ indicated that the statement did not apply to them.

Eight respondents $(9.1 \%)$ strongly agreed that they considered leaving West Virginia University because of daily challenges they faced while 27 individuals (30.7\%) expressed agreement with the statement. Thirty-eight individuals (43.2\%) disagreed with the statement and 13 individuals (14.8\%) expressed strong disagreement. Two individuals (2.3\%) indicated that the statement did not apply to them.

Four individuals (4.5\%) strongly agreed with the statement that they considered leaving West Virginia University because they were immature while 11 (12.5\%) expressed agreement with the statement. Thirty-six respondents (40.9\%) disagreed with the statement and 35 individuals (39.8\%) expressed strong disagreement. Two individuals $(2.3 \%)$ indicated that the statement did not apply to them. 
Table 26

Homesick/Personal Factors Affecting Consideration to Leave West Virginia University

\begin{tabular}{|c|c|c|c|c|c|c|c|c|c|c|}
\hline & \multicolumn{2}{|c|}{ Strongly Agree } & \multicolumn{2}{|c|}{ Agree } & \multicolumn{2}{|c|}{ Disagree } & \multicolumn{2}{|c|}{ Strongly Disagree } & \multicolumn{2}{|c|}{ Not Applicable } \\
\hline & $\mathrm{N}$ & $\%$ & $\mathrm{~N}$ & $\%$ & $\mathrm{~N}$ & $\%$ & $\mathrm{~N}$ & $\%$ & $\mathrm{~N}$ & $\%$ \\
\hline I felt alone & 16 & 18.2 & 31 & 35.2 & 27 & 30.7 & 13 & 14.8 & 1 & 1.1 \\
\hline Daily challenges that faced me & 8 & 9.1 & 27 & 30.7 & 38 & 43.2 & 13 & 14.8 & 2 & 2.3 \\
\hline I was immature & 4 & 4.5 & 11 & 12.5 & 36 & 40.9 & 35 & 39.8 & 2 & 2.3 \\
\hline Mental conditions & 3 & 3.4 & 12 & 13.6 & 33 & 37.5 & 34 & 38.6 & 6 & 6.8 \\
\hline Personal stress & 15 & 17.0 & 52 & 59.1 & 14 & 15.9 & 6 & 6.8 & 1 & 1.1 \\
\hline Too much partying & 3 & 3.4 & 15 & 17.0 & 28 & 31.8 & 40 & 45.5 & 2 & 2.3 \\
\hline Lack of self control & 2 & .8 & 20 & 7.7 & 97 & 37.5 & 84 & 32.4 & 56 & 21.6 \\
\hline
\end{tabular}


Three individuals (3.4\%) strongly agreed with the statement that mental conditions played a role in their consideration to leave West Virginia University while 12 respondents (13.6\%) expressed agreement to the statement. Thirty-three individuals (37.5\%) disagreed with the statement and 34 respondents (38.6\%) expressed strong disagreement. Six individuals (6.8\%) indicated that the statement did not apply to them.

Fifteen individuals (17.0\%) strongly agreed with the statement that personal stress was an issue in their consideration to leave West Virginia University while 52 respondents (59.1\%) expressed agreement with the statements. Fourteen respondents (15.9\%) disagreed with the statement and six individuals (6.8\%) expressed strong disagreement. One individual (1.1\%) indicated that the statement did not apply to them.

Three respondents (3.4\%) strongly agreed with the statement of too much partying was a consideration to leave West Virginia University while 15 individuals (17.0\%) expressed agreement with the statement. Twenty-eight respondents (31.8\%) disagreed with the statement and 40 individuals (45.5\%) expressed strong disagreement. Two individuals (2.3\%) indicated that the statement did not apply to them (see Table 26).

Two individuals (.8\%) strongly agreed that they considered leaving West Virginia University because they had a lack of self control while 20 respondents (7.7\%) expressed agreement with the statement. Ninety-seven respondents (37.5\%) disagreed with the statement and 84 individuals (32.4\%) expressed strong disagreement. Fifty-six individuals (21.6\%) indicated that the statement did not apply to them (see Table 26).

\section{Faculty as Factors Affecting Consideration to Leave West Virginia University}

Nine individuals (10.2\%) strongly agreed that they considered leaving West Virginia University because they were frustrated with instructors while 27 respondents 
(30.7\%) expressed agreement with the statement. Thirty-nine individuals (44.3\%) disagreed with the statement and 12 respondents (13.6\%) expressed strong disagreement. One individual (1.1\%) indicated that the statement did not apply to them.

Five respondents (5.7\%) strongly agreed considered leaving West Virginia University because professors were not willing to help while 19 individuals (21.6\%) expressed agreement with the statement. Fifty individuals (56.8\%) disagreed with the statement and 13 respondents (14.8\%) expressed strong disagreement. One individual $(1.1 \%)$ indicated that the statement did not apply to them.

Ten respondents (3.8\%) strongly agreed that they considered leaving West Virginia University because they encountered rude professors while 27 individuals (10.4\%) agreed with the statement. One hundred fourteen (43.8\%) disagreed with the statement and 54 respondents (20.8\%) expressed strong disagreement. Fifty-five individuals expressed that the statement did not apply to them (see Table 27). 
Table 27

Faculty as Factors Affecting Consideration to Leave West Virginia University

\begin{tabular}{lccccccccccc}
\hline & \multicolumn{3}{c}{ Strongly Agree } & \multicolumn{2}{c}{ Agree } & & \multicolumn{2}{c}{ Disagree } & \multicolumn{2}{c}{ Strongly Disagree } & Not Applicable \\
\cline { 2 - 9 } & $\mathrm{N}$ & $\%$ & $\mathrm{~N}$ & $\%$ & $\mathrm{~N}$ & $\%$ & $\mathrm{~N}$ & $\%$ & $\mathrm{~N}$ & $\%$ \\
\hline Frustration with instructors & 9 & 10.2 & 27 & 30.7 & 39 & 44.3 & 12 & 13.6 & 1 & 1.1 \\
Professors weren't willing to help & 5 & 5.7 & 19 & 21.6 & 50 & 56.8 & 13 & 14.8 & 1 & 1.1 \\
Rude professors & 10 & 3.8 & 27 & 10.4 & 114 & 43.8 & 54 & 20.8 & 55 & 21.2 \\
\hline
\end{tabular}




\section{Changes at West Virginia University}

The respondents were given a series of statements concerning changes they would like to see at the University. Those statements were then broken down to six different subject areas. Thirty-five individuals (13.2\%) strongly agreed that they would like to see better freshmen introduction classes while 104 respondents (39.1\%) expressed agreement with the statement. Ninety-five individuals (35.7\%) disagreed with the statement and 17 respondents (6.4\%) expressed strong disagreement. Fifteen individuals (5.6\%) indicated that the statement did not apply to them.

A majority of the respondents $(\mathrm{N}=213,80.1 \%)$ agreed that the University should increase the availability of classes at West Virginia University with 70 respondents (26.3\%) strongly agreeing with the statement and 143 individuals (53.8\%) expressing agreement with the statement. Forty-one individuals (15.4\%) expressed disagreement with the statement and nine individuals (3.4\%) expressed strong disagreement. Three individuals $(1.1 \%)$ indicated that the statement did not apply to them.

Seventy-eight respondents (29.2\%) strongly agreed that the University should increase the number of online courses while 116 individuals (43.4\%) expressed agreement with the statement. Fifty-five individuals (20.6\%) disagreed with the statement and 10 respondents (3.7\%) expressed strong disagreement. Eight individuals $(3.0 \%)$ indicated that the statement did not apply to them. 
Table 28

Student Recommendations for Class Changes at West Virginia University

\begin{tabular}{|c|c|c|c|c|c|c|c|c|c|c|}
\hline & \multicolumn{2}{|c|}{ Strongly Agree } & \multicolumn{2}{|c|}{ Agree } & \multicolumn{2}{|c|}{ Disagree } & \multicolumn{2}{|c|}{ Strongly Disagree } & \multicolumn{2}{|c|}{ Not Applicable } \\
\hline & $\mathrm{N}$ & $\%$ & $\mathrm{~N}$ & $\%$ & $\mathrm{~N}$ & $\%$ & $\mathrm{~N}$ & $\%$ & $\mathrm{~N}$ & $\%$ \\
\hline Better freshmen intro classes & 35 & 13.2 & 104 & 39.1 & 95 & 35.7 & 17 & 6.4 & 15 & 5.6 \\
\hline Increase the availability of classes & 70 & 26.3 & 143 & 53.8 & 41 & 15.4 & 9 & 3.4 & 3 & 1.1 \\
\hline $\begin{array}{l}\text { Increase the number of online } \\
\text { classes }\end{array}$ & 78 & 29.2 & 116 & 43.4 & 55 & 20.6 & 10 & 3.7 & 8 & 3.0 \\
\hline Less complicated class scheduling & 82 & 30.9 & 99 & 37.4 & 69 & 26.0 & 9 & 3.4 & 6 & 2.3 \\
\hline Less core curriculum & 55 & 20.7 & 80 & 30.1 & 98 & 36.8 & 26 & 9.8 & 7 & 2.6 \\
\hline $\begin{array}{l}\text { More transitional support for } \\
\text { incoming students }\end{array}$ & 44 & 16.6 & 136 & 51.3 & 73 & 27.5 & 6 & 2.3 & 6 & 2.3 \\
\hline Smaller classes & 46 & 17.2 & 115 & 43.1 & 94 & 35.2 & 9 & 3.4 & 3 & 1.1 \\
\hline $\begin{array}{l}\text { Teach classes on multiple } \\
\text { campuses }\end{array}$ & 63 & 23.7 & 108 & 40.6 & 76 & 28.6 & 11 & 4.1 & 8 & 3.0 \\
\hline
\end{tabular}


Eighty-two individuals (30.9\%) strongly agreed with the statement that there should be a less complicated class scheduling system while 99 respondents (37.4\%) expressed agreement with the statement. Sixty-nine individuals (26.0\%) disagreed with the statement and nine respondents (3.4\%) expressed strong disagreement. Six individuals $(2.3 \%)$ indicated that the statement did not apply to them.

Fifty-five individuals (20.7\%) strongly agreed that there needs to be less core curriculum while 80 respondents (30.1\%) expressed agreement with the statement. Ninety-eight respondents (36.8\%) disagreed with the statement and 26 individuals $(9.8 \%)$ expressed strong disagreement. Seven individuals (2.6\%) indicated that the statement did not apply to them (see Table 28).

Forty-four respondents (16.6\%) strongly agreed that there needs to be more transitional support for incoming students at West Virginia University while 136 individuals (51.3\%) expressed agreement with this statement. Seventy-three individuals (27.5\%) disagreed with the statement and six individuals (2.3\%) expressed strong disagreement. Six individuals (2.3\%) indicated that the statement did not apply to them.

Forty-six of the respondents (17.2\%) strongly agreed with the statement that they would like to see smaller classes at West Virginia University while 115 respondents (43.1\%) expressed agreement with the statement. Ninety-four individuals (35.2\%) disagreed with the statement and nine individuals (3.4\%) expressed strong disagreement. Three individuals (1.1\%) indicated that the statement did not apply to them.

Sixty-three individuals (23.7\%) strongly agreed with the statement that West Virginia University needed to teach classes on multiple campuses while 108 respondents (40.6\%) expressed agreement with the statement. Seventy-six individuals (28.6\%) 
disagreed with the statement and 11 respondents (4.1\%) expressed strong disagreement. Eight individuals (3.0\%) indicated that the statement did not apply to them (see Table 28).

\section{Recommended Financial Changes for WVU}

A majority of the respondents $(\mathrm{N}=222,83.8 \%)$ agreed with the statement about more affordable housing was needed at West Virginia University with 112 respondents (42.3\%) strongly agreeing with the statement and 110 individuals (41.5\%) expressing agreement with the statement. Twenty-seven individuals (10.2\%) disagreed with the statement and four respondents (1.5\%) expressed strong disagreement. Twelve individuals (4.5\%) indicated that the statement did not apply to them.

One hundred thirty-four respondents $(50.6 \%)$ agreed with the statement that WVU should increase financial aid and grants while 99 respondents (37.4\%) expressed agreement with this statement. Seventeen individuals (6.4\%) disagreed with the statement and four respondents (1.5\%) expressed strong disagreement. Eleven individuals (4.2\%) indicated that the statement did not apply to them.

One hundred sixteen individuals (43.6\%) strongly agreed with the statement that there should be opportunities to opt out of certain fees (recreation center, football) at West Virginia University while 103 individuals (38.7\%) expressed agreement with the statement. Thirty-two individuals (12.0\%) disagreed with the statement and seven respondents (2.6\%) expressed strong disagreement. Eight individuals (3.0\%) indicated that the statement did not apply to them. 
Table 29

Student Recommendations for Financial Changes at West Virginia University

\begin{tabular}{|c|c|c|c|c|c|c|c|c|c|c|}
\hline & \multicolumn{2}{|c|}{ Strongly Agree } & \multicolumn{2}{|c|}{ Agree } & \multicolumn{2}{|c|}{ Disagree } & \multicolumn{2}{|c|}{ Strongly Disagree } & \multicolumn{2}{|c|}{ Not Applicable } \\
\hline & $\mathrm{N}$ & $\%$ & $\mathrm{~N}$ & $\%$ & $\mathrm{~N}$ & $\%$ & $\mathrm{~N}$ & $\%$ & $\mathrm{~N}$ & $\%$ \\
\hline Affordable housing & 112 & 42.3 & 110 & 41.5 & 27 & 10.2 & 4 & 1.5 & 12 & 4.5 \\
\hline Increase financial aid and grants & 134 & 50.6 & 99 & 37.4 & 17 & 6.4 & 4 & 1.5 & 11 & 4.2 \\
\hline $\begin{array}{l}\text { Opportunity to opt out of certain } \\
\text { fees (rec center, football) }\end{array}$ & 116 & 43.6 & 103 & 38.7 & 32 & 12.0 & 7 & 2.6 & 8 & 3.0 \\
\hline Tuition costs & 103 & 38.9 & 103 & 38.9 & 45 & 17.0 & 6 & 2.3 & 8 & 3.0 \\
\hline
\end{tabular}


One hundred three individuals (38.9\%) strongly agreed with the statement that tuition costs should change at West Virginia University while 103 individuals (38.9\%) expressed agreement with the statement. Forty-five individuals (17.0\%) disagreed with the statement and six individuals (2.3\%) expressed strong disagreement with the statement. Eight individuals (3.0\%) indicated that the statement did not apply to them (see Table 29).

\section{Recommend Food Services Changes at WVU}

Eighty-two individuals (30.9\%) strongly agreed that there should be changes to the food on campus while 109 respondents (41.1\%) expressed agreement to the statement. Forty-one individuals (15.5\%) disagreed with the statement and six respondents (2.3\%) expressed strong disagreement. Twenty-seven individuals (10.2\%) indicated that the statement did not apply to them.

Ninety-eight individuals (36.8\%) strongly agreed there should be more flexible meal plan options for the Mountainlair while 106 individuals (39.8\%) express agreement to the statement. Twenty-four individuals $(9.0 \%)$ disagreed with the statement and three respondents (1.1\%) expressed strong disagreement. Thirty-five individuals (13.2\%) indicated that the statement did not apply to them.

Forty-one individuals (15.5\%) strongly agreed with the recommendation to remove Barnes and Noble from the West Virginia University campus while 25 respondents $(9.5 \%)$ expressed agreement with the statement. One hundred forty-one individuals (53.4\%) disagreed with the statement and 45 individuals (17.0\%) expressed strong disagreement. Twelve individuals (4.5\%) indicated that the statement did not apply to them. 
Eighty-three individuals (31.7\%) strongly agreed with the statement of improving eCampus while 109 individuals (41.6\%) expressed agreement with this statement. Sixty individuals (22.9\%) disagreed with the statement and five individuals (1.9\%) expressed strong disagreement. Five individuals (1.9\%) indicated that the statement did not apply to them.

Forty-five individuals (17.0\%) strongly agreed that the Evansdale library should be opened earlier while 78 respondents (29.5\%) expressed agreement with the statement. Seventy-seven respondents (29.2\%) disagreed with the statement and three individuals (1.1\%) expressed strong disagreement. Sixty-one individuals (23.1\%) indicated that the statement did not apply to them.

A majority of the respondents ( $\mathrm{n}=204,77.9 \%)$ agreed with the statement that the STAR system needed improvement with 104 individuals (39.7\%) expressing strong agreement and 100 individuals (38.2\%) expressing agreement with the statement. Fortyfive respondents (17.2\%) disagreed with the statement and seven individuals (2.7\%) expressed strong disagreement. Six individuals (2.3\%) indicated that the statement did not apply to them.

One hundred twelve individuals (42.3\%) strongly agreed with the statement that the mail system at West Virginia University should be improved while 84 individuals (31.7\%) expressed agreement with the statement. Fifty-four individuals (20.4\%) disagreed with the statement and five individuals (1.9\%) expressed strong disagreement. Ten individuals (3.8\%) indicated that the statement did not apply to them (see Table 30). 
Table 30

Student Recommendations for Food/Services Changes at West Virginia University

\begin{tabular}{|c|c|c|c|c|c|c|c|c|c|c|}
\hline & \multicolumn{2}{|c|}{ Strongly Agree } & \multicolumn{2}{|c|}{ Agree } & \multicolumn{2}{|c|}{ Disagree } & \multicolumn{2}{|c|}{ Strongly Disagree } & \multicolumn{2}{|c|}{ Not Applicable } \\
\hline & $\mathrm{N}$ & $\%$ & $\mathrm{~N}$ & $\%$ & $\mathrm{~N}$ & $\%$ & $\mathrm{~N}$ & $\%$ & $\mathrm{~N}$ & $\%$ \\
\hline Food (campus) & 82 & 30.9 & 109 & 41.1 & 41 & 15.5 & 6 & 2.3 & 27 & 10.2 \\
\hline $\begin{array}{l}\text { Flexible meal plan options for the } \\
\text { Moutainlair }\end{array}$ & 98 & 36.8 & 106 & 39.8 & 24 & 9.0 & 3 & 1.1 & 35 & 13.2 \\
\hline $\begin{array}{l}\text { Remove Barnes and Noble from } \\
\text { Campus }\end{array}$ & 41 & 15.5 & 25 & 9.5 & 141 & 53.4 & 45 & 17.0 & 12 & 4.5 \\
\hline Improve eCampus & 83 & 31.7 & 109 & 41.6 & 60 & 22.9 & 5 & 1.9 & 5 & 1.9 \\
\hline Open Evansdale library earlier & 45 & 17.0 & 78 & 29.5 & 77 & 29.2 & 3 & 1.1 & 61 & 23.1 \\
\hline Improve STAR & 104 & 39.7 & 100 & 38.2 & 45 & 17.2 & 7 & 2.7 & 6 & 2.3 \\
\hline Improve the mail system & 112 & 42.3 & 84 & 31.7 & 54 & 20.4 & 5 & 1.9 & 10 & 3.8 \\
\hline
\end{tabular}




\section{Recommended Relationship Changes at WVU}

Forty-six respondents (17.5\%) strongly agreed with the statement that changes were needed to reduce hostilities in the departments while 100 individuals $(38.0 \%)$ expressed agreement with the statement. Seventy-six individuals (28.9\%) disagreed with the statement and five individuals (1.9\%) expressed strong disagreement. Thirty-six individuals (13.7\%) indicated that the statement did not apply to them.

Fifty-seven respondents (21.5\%) strongly agreed with the statement that changes were needed to improve the relationship between professor and student while 140 individuals (52.8\%) expressed agreement with the statement. Fifty-nine individuals $(22.3 \%)$ disagreed with the statement and four individuals (1.5) expressed strong disagreement. Five individuals (1.9\%) indicated that the statement did not apply to them.

Sixty-two individuals (23.4\%) strongly agreed with the statement that changes were needed to reduce the political atmosphere in the University management while 97 respondents (36.6\%) expressed agreement with the statement. Eighty individuals $(30.2 \%)$ disagreed with the statement and six individuals $(2.3 \%)$ expressed strong disagreement. Twenty individuals (7.5\%) indicated that the statement did not apply to them (see Table 31).

\section{Recommended Faculty/Teacher Changes at WVU}

One hundred fourteen individuals $(43.0 \%)$ strongly agreed with the changes of better advising while 84 individuals expressed agreement with the statement. Fifty-five individuals $(20.8 \%)$ disagreed with the statement and seven individuals $(2.6 \%)$ expressed strong disagreement. Five individuals (1.9\%) indicated that the statement did not apply to them (see Table 32). 
Table 31

Student Recommendations for Relationship Changes at West Virginia University

\begin{tabular}{|c|c|c|c|c|c|c|c|c|c|c|}
\hline & \multicolumn{2}{|c|}{ Strongly Agree } & \multicolumn{2}{|c|}{ Agree } & \multicolumn{2}{|c|}{ Disagree } & \multicolumn{2}{|c|}{ Strongly Disagree } & \multicolumn{2}{|c|}{ Not Applicable } \\
\hline & $\mathrm{N}$ & $\%$ & $\mathrm{~N}$ & $\%$ & $\mathrm{~N}$ & $\%$ & $\mathrm{~N}$ & $\%$ & $\mathrm{~N}$ & $\%$ \\
\hline Reduce hostilities in the departments & 46 & 17.5 & 100 & 38.0 & 76 & 28.9 & 5 & 1.9 & 36 & 13.7 \\
\hline $\begin{array}{l}\text { Improve the relationship between } \\
\text { professor and student }\end{array}$ & 57 & 21.5 & 140 & 52.8 & 59 & 22.3 & 4 & 1.5 & 5 & 1.9 \\
\hline $\begin{array}{l}\text { Reduce political atmosphere in the } \\
\text { university management }\end{array}$ & 62 & 23.4 & 97 & 36.6 & 80 & 30.2 & 6 & 2.3 & 20 & 7.5 \\
\hline
\end{tabular}

Table 32

Student Recommendations for Faculty Changes at West Virginia University

\begin{tabular}{lcccccccccc}
\hline & \multicolumn{2}{c}{ Strongly Agree } & \multicolumn{2}{c}{ Agree } & \multicolumn{2}{c}{ Disagree } & \multicolumn{2}{c}{ Strongly Disagree } & \multicolumn{2}{c}{ Not Applicable } \\
\cline { 2 - 10 } & $\mathrm{N}$ & $\%$ & $\mathrm{~N}$ & $\%$ & $\mathrm{~N}$ & $\%$ & $\mathrm{~N}$ & $\%$ & $\mathrm{~N}$ & $\%$ \\
\hline Better advising & 114 & 43.0 & 84 & 31.7 & 55 & 20.8 & 7 & 2.6 & 5 & 1.9 \\
Improve professor-student ratio & 75 & 28.5 & 129 & 49.0 & 51 & 19.4 & 0 & .0 & 8 & 3.0 \\
Increase eCampus use & 55 & 20.9 & 81 & 30.8 & 95 & 36.1 & 22 & 8.4 & 10 & 3.8 \\
\hline
\end{tabular}


Seventy-five individuals (28.5\%) strongly agreed with the statement that changes were needed to improve professor-student ratio while 129 individuals $(49.0 \%)$ agreed with the statement. Fifty-one individuals (19.4\%) disagreed with the statement. Eight individuals (3.0\%) indicated that the statement did not apply to them.

Fifty-five respondents (20.9\%) strongly agreed with the statement that changes were needed to increase eCampus use while 81 individuals (30.8\%) expressed agreement with the statement. Ninety-five individuals (36.1\%) disagreed with the statement and 22 respondents (8.4\%) expressed strong disagreement. Ten individuals (3.8\%) indicated that the statement did not apply to them (see Table 32).

\section{Recommended Transportation Changes at WVU}

Eighty-six respondents (32.7\%) strongly agreed with the statement that WVU needs to improve commuter accommodations while 102 individuals (38.8\%) expressed agreement with the statement. Forty-six individuals disagreed with the statement. Twenty-nine individuals (11.0\%) indicated that the statement did not apply to them.

One hundred ninety-six individuals (75.1\%) strongly agreed with the statement that changes were needed to improve the traffic flow at West Virginia University while 54 respondents (20.7\%) expressed agreement with the statement. Five individuals (1.9\%) disagreed with the statement and one respondent (.4\%) expressed strong disagreement. Five individuals (1.9\%) indicated that the statement did not apply to them. 
Table 33

Student Recommendations for Transportation Changes at West Virginia University

\begin{tabular}{|c|c|c|c|c|c|c|c|c|c|c|}
\hline & \multicolumn{2}{|c|}{ Strongly Agree } & \multicolumn{2}{|c|}{ Agree } & \multicolumn{2}{|c|}{ Disagree } & \multicolumn{2}{|c|}{ Strongly Disagree } & \multicolumn{2}{|c|}{ Not Applicable } \\
\hline & $\mathrm{N}$ & $\%$ & $\mathrm{~N}$ & $\%$ & $\mathrm{~N}$ & $\%$ & $\mathrm{~N}$ & $\%$ & $\mathrm{~N}$ & $\%$ \\
\hline $\begin{array}{l}\text { Improve commuter } \\
\text { accommodations }\end{array}$ & 86 & 32.7 & 102 & 38.8 & 46 & 17.5 & 0 & .0 & 29 & 11.0 \\
\hline Improve traffic flow & 196 & 75.1 & 54 & 20.7 & 5 & 1.9 & 1 & .4 & 5 & 1.9 \\
\hline Improve walkways & 154 & 58.6 & 75 & 28.5 & 28 & 10.6 & 2 & .8 & 4 & 1.5 \\
\hline Increase available parking & 218 & 83.2 & 34 & 13.0 & 4 & 1.5 & 1 & .4 & 5 & 1.9 \\
\hline Improve PRT & 192 & 72.7 & 52 & 19.7 & 8 & 3.0 & 2 & .8 & 10 & 3.8 \\
\hline $\begin{array}{l}\text { Provide safer walk from Coliseum } \\
\text { to Evansdale Campus }\end{array}$ & 157 & 59.9 & 59 & 22.5 & 23 & 8.8 & 0 & .0 & 23 & 8.8 \\
\hline
\end{tabular}


One hundred fifty-four individuals (58.6\%) strongly agreed with the statement that changes were needed to improve walkways at West Virginia University while 75 respondents (28.5\%) expressed agreement with the statement. Twenty-eight individuals (10.6\%) disagreed with the statement and two individuals (.8\%) expressed strong disagreement. Four individuals $(1.5 \%)$ indicated that the statement did not apply to them.

Two hundred eighteen individuals (83.2\%) strongly agreed with the statement that changes were needed to increase available parking at West Virginia University while 34 respondents (13.0\%) expressed agreement with the statement. Four individuals (1.5\%) disagreed with the statement and one individual (.4\%) expressed strong disagreement. Five individuals (1.9\%) indicated that the statement did not apply to them.

One hundred ninety-two individuals (72.7\%) strongly agreed with the statement that changes were needed to improve the PRT while 52 respondents (19.7\%) expressed agreement to the statement. Eight individuals (3.0\%) disagreed with the statement and two respondents (.8\%) expressed strong disagreement. Ten individuals (3.8\%) indicated that the statement did not apply to them.

One hundred fifty-seven respondents (59.9\%) strongly agreed with the statement that changes were needed to provide a safer walk from the Coliseum to the Evansdale campus while 59 respondents (22.5\%) expressed agreement with the statement. Twentythree respondents $(8.8 \%)$ disagreed with the statement. Twenty-three individuals $(8.8 \%)$ indicated that the statement did not apply to them (see Table 33).

\section{Academic Challenges that Faced Respondents}

The respondents were presented with an array of statements on challenges they have faced during their college career. Those statements were then further divided into 
categories. Thirty-six respondents $(13.7 \%)$ strongly agreed with the statement that poor study skills were a challenge for them at West Virginia University while 95 individuals (36.1\%) expressed agreement with the statement. Ninety-eight individuals $(37.3 \%)$ disagreed with the statement and 32 respondents (12.2\%) expressed strong disagreement. Two individuals $(.8 \%)$ indicated that the statement did not apply to them.

Fifty-six respondents (21.3\%) strongly agreed with the statement that bad advising was a challenge for them at West Virginia University while 79 individuals expressed agreement with the statement. Ninety-four respondents $(35.7 \%)$ disagreed with the statement and 28 individuals (10.6\%) expressed strong disagreement. Five individuals $(1.9 \%)$ indicated that the statement did not apply to them.

Twelve individuals (4.5\%) strongly agreed that they were challenged with classes that were too difficult while 42 respondents (15.9\%) expressed agreement with the statement. One hundred seventy-eight respondents (67.4\%) disagreed with the statement and 27 individuals (10.2\%) expressed strong disagreement. Five individuals (1.9\%) indicated that the statement did not apply to them.

Twenty-three individuals (8.8\%) strongly agreed that they were challenged when teachers make it difficult to focus while 75 individuals $(28.6 \%)$ agreed with the statement. One hundred forty-one individuals (53.8\%) disagreed with the statement and 20 individuals (7.6\%) expressed strong disagreement. Three individuals (1.1\%) indicated that the statement did not apply to them (see Table 34).

\section{Facility Issues That Faced Respondents}

Twenty-eight individuals (10.7\%) strongly agreed with the statement that difficult living situations were a challenge at West Virginia University while 77 respondents 
(29.5\%) expressed agreement with the statement. One hundred thirty-two respondents (50.6\%) disagreed with the statement and 19 respondents (7.3\%) strongly disagreed with the statements. Five individuals (1.9\%) indicated that the statement did not apply to them.

One hundred thirty-six respondents (51.9\%) strongly agreed with the statement that dealing with parking issues was a challenge at West Virginia University while 80 respondents (30.5\%) expressed agreement with the statement. Twenty-five individuals (9.5\%) disagreed with the statement and nine individuals (3.4\%) expressed strong disagreement. Twelve individuals (4.6\%) indicated that the statement did not apply to them (see Table 35).

\section{Family/Homesick Issues That Faced Students at WVU}

Nineteen individuals (7.3\%) strongly agreed that family issues were challenges they faced while 49 individuals (18.8\%) expressed agreement to the statement. One hundred thirty-two respondents (50.6\%) disagreed with the statement and 51 respondents (19.5\%) expressed strong disagreement. Ten individuals (3.8\%) indicated that the statement did not apply to them (see Table 36).

Fifty-four respondents (20.5\%) strongly agreed with the statement that financial situations were challenges they faced while 71 individuals (27.0\%) expressed agreement with the statement. One hundred two individuals (38.8\%) disagreed with the statement and 29 respondents (11.0\%) expressed strong disagreement. Seven individuals (2.7\%) indicated that the statement did not apply to them. 
Table 34

Academic Difficulties that Challenged Students at West Virginia University

\begin{tabular}{lccccccccccc}
\hline & \multicolumn{2}{c}{ Strongly Agree } & \multicolumn{2}{c}{ Agree } & \multicolumn{2}{c}{ Disagree } & \multicolumn{2}{c}{ Strongly Disagree } & Not Applicable \\
\cline { 2 - 10 } & $\mathrm{N}$ & $\%$ & $\mathrm{~N}$ & $\%$ & $\mathrm{~N}$ & $\%$ & $\mathrm{~N}$ & $\%$ & $\mathrm{~N}$ & $\%$ \\
\hline Poor study skills & 36 & 13.7 & 95 & 36.1 & 98 & 37.3 & 32 & 12.2 & 2 & .8 \\
Bad advising & 56 & 21.3 & 79 & 30.0 & 94 & 35.7 & 28 & 10.6 & 6 & 2.3 \\
Classes were too difficult & 12 & 4.5 & 42 & 15.9 & 178 & 67.4 & 27 & 10.2 & 5 & 1.9 \\
Teachers made it difficult to focus & 23 & 8.8 & 75 & 28.6 & 141 & 53.8 & 20 & 7.6 & 3 \\
\hline
\end{tabular}

Table 35

Facilities Issues that Challenged Students at West Virginia University

\begin{tabular}{lcccccccccc}
\hline & \multicolumn{2}{c}{ Strongly Agree } & \multicolumn{2}{c}{ Agree } & \multicolumn{2}{c}{ Disagree } & \multicolumn{2}{c}{ Strongly Disagree } & Not Applicable \\
\cline { 2 - 9 } & $\mathrm{N}$ & $\%$ & $\mathrm{~N}$ & $\%$ & $\mathrm{~N}$ & $\%$ & $\mathrm{~N}$ & $\%$ & $\mathrm{~N}$ & $\%$ \\
\hline Difficult living situation & 28 & 10.7 & 77 & 29.5 & 132 & 50.6 & 19 & 7.3 & 5 & 1.9 \\
Parking issues & 136 & 51.9 & 80 & 30.5 & 25 & 9.5 & 9 & 3.4 & 12 & 4.6 \\
\hline
\end{tabular}


Table 36

Family/homesick Issues that Challenged Students at West Virginia University

\begin{tabular}{lccccccccccc}
\hline & \multicolumn{2}{c}{ Strongly Agree } & \multicolumn{2}{c}{ Agree } & \multicolumn{2}{c}{ Disagree } & \multicolumn{2}{c}{ Strongly Disagree } & \multicolumn{2}{c}{ Not Applicable } \\
\cline { 2 - 9 } & $\mathrm{N}$ & $\%$ & $\mathrm{~N}$ & $\%$ & $\mathrm{~N}$ & $\%$ & $\mathrm{~N}$ & $\%$ & $\mathrm{~N}$ & $\%$ \\
\hline Family issues & 19 & 7.3 & 49 & 18.8 & 132 & 50.6 & 51 & 19.5 & 10 & 3.8 \\
Financial situation & 54 & 20.5 & 71 & 27.0 & 102 & 38.8 & 29 & 11.0 & 7 & 2.7 \\
Over protective parents & 13 & 4.9 & 37 & 14.1 & 122 & 46.4 & 79 & 30.0 & 12 & 4.6 \\
I was homesick & 19 & 7.3 & 56 & 21.5 & 120 & 46.2 & 60 & 23.1 & 5 & 1.9 \\
Lack of support & 13 & 5.0 & 32 & 12.4 & 145 & 56.0 & 67 & 25.9 & 2 \\
\hline
\end{tabular}


Thirteen individuals (4.9\%) strongly agreed that over protective parents was a challenge while at West Virginia University while 37 respondents (14.1\%) expressed agreement with the statement. One hundred twenty-two respondents (46.4\%) disagreed with the statement and 79 individuals (30.0\%) expressed strong disagreement. Twelve individuals (4.6\%) indicated that the statement did not apply to them.

Nineteen individuals (7.3\%) strongly agreed they feeling homesick was a challenge at West Virginia University while 56 individuals (21.5\%) expressed agreement with the statement. One hundred twenty respondents (46.2\%) disagreed with the statement and 60 respondents (23.1\%) expressed strong disagreement. Five individuals $(1.9 \%)$ indicated that the statement did not apply to them.

Thirteen respondents (5.0\%) strongly agreed that they were challenged by a lack of support at West Virginia University while 32 respondents (12.4\%) expressed agreement with the statement. One hundred forty-five respondents (56.0\%) disagreed with the statement and 67 respondents (25.9\%) expressed strong disagreement. Two individuals (.8\%) indicated that the statement did not apply to them (see Table 36).

\section{Motivational Issues That Faced Respondents}

Twenty-two individuals (8.4\%) strongly agreed that they struggled with their internal motivation at West Virginia University while 79 respondents expressed agreement with the statement. One hundred twelve respondents $(42.9 \%)$ disagreed with the statement and 45 individuals (17.2\%) expressed strong disagreement. Three individuals (1.1\%) indicated that the statement did not apply to them (see Table 37). 
Table 37

Motivation Issues that Challenged Students at West Virginia University

\begin{tabular}{|c|c|c|c|c|c|c|c|c|c|c|}
\hline & \multicolumn{2}{|c|}{ Strongly Agree } & \multicolumn{2}{|c|}{ Agree } & \multicolumn{2}{|c|}{ Disagree } & \multicolumn{2}{|c|}{ Strongly Disagree } & \multicolumn{2}{|c|}{ Not Applicable } \\
\hline & $\mathrm{N}$ & $\%$ & $\mathrm{~N}$ & $\%$ & $\mathrm{~N}$ & $\%$ & $\mathrm{~N}$ & $\%$ & $\mathrm{~N}$ & $\%$ \\
\hline $\begin{array}{l}\text { I struggled with my internal } \\
\text { motivation }\end{array}$ & 22 & 8.4 & 79 & 30.3 & 112 & 42.9 & 45 & 17.2 & 3 & 1.1 \\
\hline It became difficult to keep positive & 25 & 9.5 & 69 & 26.3 & 127 & 48.5 & 39 & 14.9 & 2 & .8 \\
\hline
\end{tabular}


Twenty-five respondents $(9.5 \%)$ strongly agreed that it became difficult for them to stay positive as a student at West Virginia University while 69 respondents (26.3\%) expressed agreement with the statement. One hundred twenty-seven respondents (48.5\%) disagreed with the statement and 39 respondents (14.9\%) expressed strong agreement. Two individuals (.8\%) indicated that the statement did not apply to them (see Table 37).

\section{Personal Issues that Challenged Student at West Virginia University}

Twenty-one respondents $(8.0 \%)$ strongly agreed with the statement that they had emotional issues while a student at West Virginia University while 73 respondents (27.9\%) expressed agreement with the statement. One hundred twenty-two individuals (46.6\%) disagreed with the statement and 39 respondents (14.9\%) expressed strong disagreement. Seven individuals $(2.7 \%)$ indicated that the statement did not apply to them.

Nineteen individuals (7.3\%) strongly agreed with the statement that they felt alone while a student at West Virginia University and 51 respondents (19.5\%) expressed agreement with the statement. One hundred twenty-eight individuals (48.9\%) disagreed with the statement and 62 respondents (23.7\%) expressed strong disagreement. Two individuals (.8\%) indicated that the statement did not apply to them.

Eleven respondents (4.2\%) strongly agreed that drinking alcohol was an issue while a student at West Virginia University while 54 respondents (20.7\%) expressed agreement with the statement. One hundred eleven respondents (42.5\%) disagreed with the statement and 78 individuals (29.9\%) expressed strong disagreement. Seven individuals $(2.7 \%)$ indicated that the statement did not apply to them. 
Table 38

Personal Issues that Challenged Students at West Virginia University

\begin{tabular}{|c|c|c|c|c|c|c|c|c|c|c|}
\hline & \multicolumn{2}{|c|}{ Strongly Agree } & \multicolumn{2}{|c|}{ Agree } & \multicolumn{2}{|c|}{ Disagree } & \multicolumn{2}{|c|}{ Strongly Disagree } & \multicolumn{2}{|c|}{ Not Applicable } \\
\hline & $\mathrm{N}$ & $\%$ & $\mathrm{~N}$ & $\%$ & $\mathrm{~N}$ & $\%$ & $\mathrm{~N}$ & $\%$ & $\mathrm{~N}$ & $\%$ \\
\hline Emotional issues & 21 & 8.0 & 73 & 27.9 & 122 & 46.6 & 39 & 14.9 & 7 & 2.7 \\
\hline I felt alone & 19 & 7.3 & 51 & 19.5 & 128 & 48.9 & 62 & 23.7 & 2 & .8 \\
\hline Drinking alcohol & 11 & 4.2 & 54 & 20.7 & 111 & 42.5 & 78 & 29.9 & 7 & 2.7 \\
\hline $\begin{array}{l}\text { Hard time keeping up with my } \\
\text { social life }\end{array}$ & 10 & 3.8 & 60 & 22.9 & 142 & 54.2 & 49 & 18.7 & 1 & .4 \\
\hline $\begin{array}{l}\text { Hard time with new } \\
\text { responsibilities }\end{array}$ & 17 & 6.5 & 63 & 24.0 & 141 & 53.8 & 38 & 14.5 & 3 & 1.1 \\
\hline I was immature & 10 & 3.8 & 36 & 13.8 & 131 & 50.2 & 81 & 31.0 & 3 & 1.1 \\
\hline Peer pressure was an issue & 9 & 3.4 & 38 & 14.6 & 140 & 53.6 & 72 & 27.6 & 2 & .8 \\
\hline Too much freedom & 7 & 2.7 & 35 & 13.5 & 145 & 56.0 & 70 & 27.0 & 2 & .8 \\
\hline
\end{tabular}


Ten respondents (3.8\%) strongly agreed with the statement that they had a hard time keeping with their social life while 60 individuals (22.9\%) expressed agreement with the statement. One hundred forty-two respondents (54.2\%) disagreed with the statement and 49 respondents (18.7\%) expressed strong disagreement. One individual (.4\%) indicated that the statement did not apply to them.

Seventeen respondents (6.5\%) strongly agreed that they had a hard time with new responsibilities at college while 63 individuals (24.0\%) expressed agreement with the statement. One hundred forty-one respondents (53.8\%) disagreed with the statement and 38 individuals (14.5\%) expressed strong disagreement. Three individuals (1.1\%) indicated that the statement did not apply to them.

Ten respondents (3.8\%) strongly agreed with the statement that they were immature while 36 respondents (13.8\%) expressed agreement with the statement. One hundred thirty-one respondents (50.2\%) disagreed with the statement and 81 individuals (31.0\%) expressed strong disagreement. Three individuals (1.1\%) indicated that the statement did not apply to them.

Nine respondents (3.4\%) strongly agreed that peer pressure was an issue at West Virginia University while 38 respondents (14.6\%) expressed agreement with the statement. One hundred forty respondents (53.6\%) disagreed with the statement and 72 individuals (27.6\%) expressed strong disagreement. Two individuals (.8\%) indicated that the statement did not apply to them.

Seven respondents (2.7\%) strongly agreed that having too much freedom was a challenge at West Virginia University while 35 individuals (13.5\%) expressed agreement with the statement. One hundred forty-five respondents (56.0\%) disagreed with the 
statement and 70 individuals (27.0\%) expressed strong disagreement. Two individuals $(.8 \%)$ indicated that the statement did not apply to them (see Table 38).

\section{Time Issues Faced By Respondents}

Thirty-eight respondents (14.7\%) strongly agreed with the statement that stress management was an issue for them at West Virginia University while 98 respondents (37.8\%) expressed agreement with the statement. Ninety-one respondents (35.1\%) disagreed with the statement and 31 respondents (12.0\%) expressed strong disagreement. One individual (.4\%) indicated that the statement did not apply to them.

Sixteen respondents (6.1\%) strongly agreed with the statement that the balance of work and school became too much while 54 respondents (20.7\%) expressed agreement with the statement. One hundred eighteen individuals (45.2\%) disagreed with the statement and 41 respondents (15.7\%) expressed strong disagreement. Thirty-two individuals (12.3\%) indicated that the statement did not apply to them.

Twenty-three respondents (8.8\%) strongly agreed that organizational skills were an issue for them at West Virginia University while 76 respondents (29.2\%) expressed agreement with the statement. One hundred nine respondents (41.9\%) disagreed with the statement and 50 respondents (19.2\%) expressed strong disagreement. Two individuals $(.8 \%)$ indicated that the statement did not apply to them.

Thirty-two respondents (12.3\%) strongly agreed with the statement that time management was an issue for them at West Virginia University while 105 respondents (40.4\%) expressed agreement with the statement. Ninety-two respondents (35.4\%) disagreed with the statement and 30 respondents (11.5\%) expressed strong disagreement. One individual (.4\%) indicated that the statement did not apply to them (see Table 39). 
Table 39

Time Issues that Challenged Students at West Virginia University

\begin{tabular}{|c|c|c|c|c|c|c|c|c|c|c|}
\hline & \multicolumn{2}{|c|}{ Strongly Agree } & \multicolumn{2}{|c|}{ Agree } & \multicolumn{2}{|c|}{ Disagree } & \multicolumn{2}{|c|}{ Strongly Disagree } & \multicolumn{2}{|c|}{ Not Applicable } \\
\hline & $\mathrm{N}$ & $\%$ & $\mathrm{~N}$ & $\%$ & $\mathrm{~N}$ & $\%$ & $\mathrm{~N}$ & $\%$ & $\mathrm{~N}$ & $\%$ \\
\hline Stress management was an issue & 38 & 14.7 & 98 & 37.8 & 91 & 35.1 & 31 & 12.0 & 1 & .4 \\
\hline $\begin{array}{l}\text { Balance of work and school } \\
\text { became too much }\end{array}$ & 16 & 6.1 & 54 & 20.7 & 118 & 45.2 & 41 & 15.7 & 32 & 12.3 \\
\hline Organizational skills & 23 & 8.8 & 76 & 29.2 & 109 & 41.9 & 50 & 19.2 & 2 & .8 \\
\hline Time management was an issue & 32 & 12.3 & 105 & 40.4 & 92 & 35.4 & 30 & 11.5 & 1 & .4 \\
\hline
\end{tabular}




\section{Generalized Summary Statements Expressed by the Respondents}

Given four possible answers, respondents were asked to indicate what motivated them to pursue a degree at West Virginia University. Sixty-one respondents $(23.3 \%)$ indicated money was a motivation. Forty-eight individuals (18.3\%) indicated stability. One hundred thirty-one respondents $(50.0 \%)$ indicated personal goals and security had 22 respondents $(8.4 \%)$ (see Table 40$)$.

Table 40

Motivations to Pursue a Degree

\begin{tabular}{lcc}
\hline & $\mathrm{N}$ & $\%$ \\
\hline Personal Goals & 131 & 50.0 \\
Money & 61 & 23.3 \\
Stability & 48 & 18.3 \\
Security & 22 & 8.4 \\
\hline
\end{tabular}

Using three possible choices the respondents were asked to indicate suggested changes at West Virginia University. One hundred fifty-five respondents (59.2\%) indicated changes were needed in parking availability. Twenty-four respondents $(9.2 \%)$ expressed travel opportunity as a change and 83 individuals $(31.7 \%)$ indicated they would like to see more financial assistance (see Table 41). 
Table 41

Suggested Changes at West Virginia University

\begin{tabular}{lcc}
\hline & $\mathrm{N}$ & $\%$ \\
\hline Parking availability & 155 & 59.2 \\
Financial assistance & 83 & 31.7 \\
Travel opportunity & 24 & 9.2 \\
\hline
\end{tabular}

The respondents were asked to indicate the type of parental support they had received. They had the option of choosing more than one statement. Two hundred twenty-four respondents $(80.0 \%)$ indicated that their parents provided motivational support. One hundred seventy-eight individuals (63.6\%) indicated that their parents provided financial support. Sixty-four respondents $(22.9 \%)$ indicated their parents provided study support and 69 individuals $(24.6 \%)$ indicated their parents provided some other support (see Table 42).

Table 42

Parental Support

\begin{tabular}{lcc}
\hline & $\mathrm{N}$ & $\%$ \\
\hline Motivation & 224 & 80.0 \\
Financials & 178 & 63.6 \\
Other & 69 & 24.6 \\
Study Skills & 64 & 22.9 \\
\hline
\end{tabular}

The respondents were asked to indicate individuals who had provided encouragement. They had the option of choosing more than one option. Two hundred 
forty-five respondents $(87.5 \%)$ indicated that their parents had provided encouragement and 171 individuals (61.1\%) expressed teachers as an encouraging force. Both professors and advisors were indicated by 116 respondents (41.4\%) who thought they had encouraged them. Two hundred seventeen respondents (77.5\%) indicated that friends had encouraged them while 231 individuals (82.5\%) indicated family (see Table 43).

Table 43

Individuals that Provided Encouragement

\begin{tabular}{lcc}
\hline & $\mathrm{N}$ & $\%$ \\
\hline Parents & 245 & 87.5 \\
Family & 231 & 82.5 \\
Friends & 217 & 77.5 \\
Teachers & 171 & 61.1 \\
Professors & 116 & 41.4 \\
Advisors & 116 & 41.4 \\
\hline
\end{tabular}

The respondents were asked to indicate the many study techniques that they have used as a student at West Virginia University. They had the option of choosing more than one response. One hundred fifty-two respondents (54.3\%) had used study-groups, and 203 respondents $(72.5 \%)$ had studied in the library alone. One hundred eighty-three respondents (65.4\%) used friends to study and 42 individuals (15.0\%) used family. Seventy-five respondents (26.8\%) used professors to study (see Table 44). 
Table 44

Study Techniques Used at West Virginia University

\begin{tabular}{lcc}
\hline & $\mathrm{N}$ & $\%$ \\
\hline Library Alone & 203 & 72.5 \\
Friends & 183 & 65.4 \\
Study-Group & 152 & 54.3 \\
Professors & 75 & 26.8 \\
Family & 42 & 15.0 \\
\hline
\end{tabular}




\section{CHAPTER V}

\section{Summary, Conclusions, and Recommendations}

\section{Problem Statement}

High school students throughout the world are making drastic decisions that will inevitably steer their life directions; decisions on where to go to college, what degree to pursue, or even if they want to go to college at all. Focusing efforts on what motivates students to choose West Virginia University will give insight into what can be expanded on to encourage more students to enroll. However, there are many issues that pull students away from the University once getting here and understanding their motives to stay and considerations on leaving will give the University some insight to the issues that students are dealing with today.

\section{Purpose and Objectives of the Study}

The purpose of this study was to determine the motivational forces that encourage students to enroll at West Virginia University. It was also designed to understand what motivated the students to continue to pursue their degrees. This study will be helpful in finding and understanding key motivational factors that encourage students to enroll at WVU. The study will also help professors and advisors better understand their students and help them in developing a better understanding of student issues.

The objectives of the study are reflected in the following research questions:

1. What are the factors that have motivated students to continue their education beyond high school?

2. What factors have challenged students during their college career? 
3. What are the issues students face when dealing with West Virginia University?

4. What are the factors, if any, that have caused the student to reconsider their position at the University?

5. What factors kept the students at West Virginia University?

\section{Summary}

The accessible population consisted of 309 students enrolled in AGEE courses. Two hundred eighty-two respondents $(90.9 \%)$ returned the questionnaire. The majority of the respondents $(53.8 \%)$ were between the age range of 18 and 20 . The majority of the respondents (59.8\%) were from West Virginia. Many colleges from West Virginia University (see Table 2) were represented in the sample but $42.3 \%$ of the respondents indicated that they were a student of the Davis College of Agriculture, Natural Resources, and Design. A majority of the students had a grade point average between a 3.0 and 3.49.

The majority of the respondents (95.8\%) were white-Caucasian and $98.4 \%$ were Non-Hispanic or Latino. When asked to identify their socio-economic status, $42.4 \%$ indicated they were part of the upper middle class ranking. Many of the respondents (70.4\%) were not first generation students. When asked if they had taken an advance placement classes, $56.1 \%$ had taken such classes in high school, however, when asked if the classes were helpful, $65 \%$ of the respondents indicated that they were not helpful.

There are many things that can be said about students who enroll at West Virginia University. A multitude of factors are considered when a student decides which college to attend. The atmosphere at West Virginia University attracts many students to enroll. The statement "I wanted to be part of the WVU social system" was expressed by 86.3 
percent of the respondents. Many of the respondents (97.1\%) indicated that enrolling at WVU was a personal goal.

One hundred sixty-nine respondents $(95.2 \%)$ indicated that their family had encouraged them to attend. Two hundred forty individuals (88.3\%) agreed with the statement that college was the first step in gaining personal independence. Most of the respondents $(94.6 \%)$ had indicated that they had a drive to succeed. The respondents agreed that a college education would give them financial security, would give them opportunity to make more money, and a college education would allow them to support a family.

Two hundred fifty-six respondents $(94.8 \%)$ indicated that their personal determination and motivation was what kept them at WVU. Many of them $(93.2 \%)$ indicated that they didn't want to be a failure. Two hundred sixty respondents $(96.3 \%)$ continued their education because of their career goals. The location of West Virginia University was a factor for the majority of the respondents $(\mathrm{N}=221,82.4 \%)$ staying at WVU.

A majority of the respondents $(\mathrm{N}=61,69.4 \%)$ disagreed with the statement that classes did not pertain to their interest. Forty-three respondents $(49.4 \%)$ agree that the students at the University are rude. Many of the respondents disagreed with statements concerning difficulty in performing school work, too much studying and poor grades as reasons they have considered leaving the University. However, 52 respondents $(59.1 \%)$ agreed that they have become discouraged along the way. The students who considering leaving WVU were also in agreement that they have felt burnt out and overwhelmed. 
Eighteen respondents (20.4\%) who considered leaving the University believed that they had been involved in too much partying. Forty-seven respondents (53.4\%) agree that they have felt alone and 67 individuals (76.1\%) agreed that they have had experienced personal stress to the point they considered leaving the University.

One hundred thirty-nine respondents (52.3\%) agree that they would like to see better freshmen intro classes. They also agreed on the increased availability of classes, increased online classes, and having smaller classrooms. Two hundred twelve individuals (83.8\%) agreed with the statement that WVU needed more affordable housing. Two hundred four respondents (77.9\%) would like to see STAR improved. One hundred ninety-eight respondents $(74.7 \%)$ would like to see better advising. Many agreed that traffic flow, walkways and available parking needs to be improved.

When asked to identify with statements concerning challenges they have faced, $51.3 \%$ of the respondents indicated they have had bad advising. A majority of the respondents (82.4\%) had experienced some type of parking issues. Respondents also indicated that they had challenges with stress management and time management.

\section{Conclusions}

Based on the results of this study, the following conclusions were made:

1. The overall atmosphere that West Virginia University portrays attracts many students to attend. Ranging from athletics to college experiences the respondents were concerned with the atmosphere at WVU (see Table 7).

2. The assumed financial security of college graduates attracts students to enroll in higher education. Anderson (1999) found also that employment opportunities were very important to a student's decision to pursue higher education. 
3. Encouragement from family and friends was key to students' motivations to enroll. Nearly $95 \%$ of the respondents had some form of encouragement from family to attend college (see Table 9).

4. Personal motivation was key to students continuing their college education.

5. The opportunity to learn and expand ones knowledge kept students at WVU.

6. The many resources that WVU provided: its size, faculty and computers attracted students to continue their education.

7. Students would often become discouraged causing them to consider leaving West Virginia University. I don't like often here. Can it be changed?????

8. Many students felt alone causing them to want to leave West Virginia University.

9. Personal stress caused respondents to reconsider their college careers.

10. Students would like to see more smaller classes offered.

11. Respondents would like to see more affordable housing in the WVU area.

12. Respondents would like improved road ways and walkways.

13. Students had many different challenges to deal with including bad advising.

14. Parking issues were a challenge for the students.

15. Stress and time management were issues for the students.

\section{Recommendations}

Anderson (1999) said that there is an increase in interest for identifying factors that influence student choices within higher education due in part to the increased competition between universities. Many of the factors and issues concerning the universities range from psychological health, physical health, and general stressors as 
indicated by Hicks (2008). Based on the findings of the research and the findings through other reading the researcher makes the following recommendations.

1. Each department should hold a team building session the second week of classes. The first week of classes are always a little jumbled with students still changing classes and even changing majors. The second week is a little calmer. According to Hirsch (1980) peer relations are critical for support, confirmation of one's identity opportunities for socialization, and other dimension of college adjustment. Pierce, Sarason, \& Sarason (1991) also found that college friends' support was the most consistent predictor of self-reported loneliness. This study did not ask that question but many students indicated that they have felt alone at some point in their college career. Many of the respondents $78 \%$, felt that their friends encouraged them to continue their education. Making friendship through team building opportunities would help cusion the transition into a new semester. Langston \& Cantor (1989) also found that many students, who experience the transition from high school to college as painful, reported disappointment in the domain of social interaction and friendships.

2. Freshmen introduction classes should be run by each department and focus on time and stress management. Hicks (2008) found that $6.7 \%$ of the on-campus student body facing stress issues related to professor relations. While $5.1 \%$ of the off-campus student body rather or highly stressed related to professor relations. By having each introduction class given by the department would strengthen professor and student relations also alleviating many stress factors. 
3. Make classes more available by decreasing class size, increasing online courses and offering classes on multiple campuses. Andersons (1999) study also found that student's decision of where to go to college depended heavily on location. It would be advantageous to offer classes on multiple locations to encourage students from different areas of the region. Having classes online will allow more non-traditional students access to education. 


\section{REFERENCES}

Anderson, P. (1999). Factors influencing student choice in higher education. Perspective, 3 (4), 128-131.

Ary, D., Jacobs, L. C., Razavieh, A., \& Sorensen, C. (2006). Introduction to research in education. Belmont: Thomson Wadsworth.

Bong, M. (2004). Academic motivation in self-efficacy, task value, achievement goal orientations, and attibutional beliefs. Journal of Educational Research , 97(6), 287-297.

Davis College of Agriculture, Natural Resources and Design. (n.d.). Retrieved October 06, 2009, from http://www.davis.wvu.edu/about_us

Ehrenberg, R. G., \& Sherman, D. R. (2009). Employment while in college, academic achievement, and postcollege outcomes: a summary of results. Journal of Human Resources , 22(1), 1,23.

Hicks, T., \& Heastie, S. (2008). High school to college transition: A profile of the stressors, physial and psychological health issues that affect the first-year oncampus college student. Journal of Cultural Diversity , 15(3), 143-147.

Hirsch, B. (1980). Natural support systems and coping with majo life changes. American Journal of Community Psychology , 8, 159-172.

Langston, C., \& Cantor, N. (1989). Social anxiety and social constraint: When making friends is hard. Journal of Personality and and Social Pyschology , 54, 159-172.

Martens, M., Rocha, T. L., Martin, J. L., \& Serrao, H. F. (????). Drinking motives and college students: Further examinationa of a four factor model. Journal of Counseling Psychology , 55 (2), 289,295.

Maslow, A. H. (1970). Motivation and personality (2nd ed. ed.). New York: Harper and Row. 
Pierce, G., Sarason, I., \& Sarason, B. (1991). General and relationship-based perceptions of social support: Are two constructs better than one? Journal of Personality and Social Psychology , 61, 1028-1039.

Steers, R. M., \& Porter, L. W. (1979). Motivation and work behavior (2nd ed. ed.). New York: McGraw-Hill.

Vansteenkiste, M., Soenens, B., \& Sierens, E. (2009). Motivational profiles from a selfdetermination perspective: The quality of motivation matters. Journal of Education Psychology , 101(3), 671,688.

Weiner, B. (1972). Theories of motivation from mechanism to cognition. Chicago: Rand McNally College Publishing.

Wolters, C. A. (1998). Self regulated learning and college students regulation of motivation. Journal Educational Psychology, 90(2), 224-235.

Zimmerman, B., \& Kitsantas, A. (2007). Reliability and validity of self-efficacy for learning form (SELF) scores of college students. Journal of Psychology , 215(3), 157-163. 
APPENDICES 


\section{APPENDIX A}

\section{Email Correspondence}


Dear West Virginia University Student:

As a student you have had many experiences with professors, advisors, and other students at West Virginia University. These experiences, along with influences from your home situation, have helped forge your decisions to enroll and remain a student at West Virginia University. To assist other students in making similar decisions, we would like to hear about your personal experiences with the college, including things you would like to change and things you liked? We know that everyone has a busy schedule but this information is crucial to future recruitment efforts. Please take a few moments of your valuable time and share your opinions with us.

I am Jeremy L. Kelly, a graduate student in Agricultural and Extension Education at West Virginia University. Under the direction of my advisor, Dr. Harry Boone, I am conducting a research study to determine the motivational factors that drive students to continue their college education. The results of this research study will be used to prepare a thesis to partially fulfill the requirements for a Master of Science degree in Agricultural and Extension Education. The results will provide insight to professors, program coordinators, and advisors at the Davis College about the factors that motivated students to attend WVU. This will also give you an opportunity to suggest ways the college experience can be improved for all students pursuing a college degree.

Participation in this research study, while voluntary, will only take a few minutes of your time. You may skip any question you are not comfortable answering or you may quit at any point and return the partially completed questionnaire. All information will be held as confidential as possible. Survey results will be reported in a summary format and individual responses will not be identifiable. There is no penalty and services will not be withheld, and grades will not be affected if you choose not to participate.

The online survey can be accessed through the following site: http://www.zoomerang.com/Survey/?p=WEB22A7LXXFURU. This link will direct you to the online questionnaire. After completing the survey click on the submit button. West Virginia University's IRB acknowledgement of this research is on file.

Please complete this study by February $14^{\text {th }}, \mathbf{2 0 1 0}$. If you have any questions please contact Dr. H. Boone at 304-293-5451 or Jeremy at 304-2935661. We thank you in advance for your participation in the study.

Sincerely,

Jeremy L. Kelly

Graduate Student
Harry N. Boone, Jr.

Associate Professor 
APPENDIX B

Online Survey 


\section{Motivations, Factors and Issues Concerning Students at West Virginia University}

If you have questions about the questionnaire please contact:

$$
\begin{aligned}
& \text { Jeremy Kelly } \\
& \text { Graduate Student }
\end{aligned}
$$

Agricultural and Extension Education

jkelly5@mix.mvu.edu

(304) 293-5661

\section{Factors Influeneing Enrollment at West Virginia University}

Instructions: Using the following Likert scale, indicate the level of influence each item had on your decision to enroll at West Virginia

University. Indicate your opinion by clicking on the button that that best correspond to your response: 1 - Strongly Agree, 2 -Agree, 3 - Disagree, 4 Strongly Disagree, or 5 - Not Applicable.

1 Athletics were important to me as a spectator.

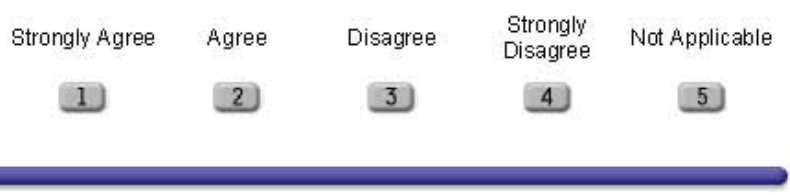

2 Athletics were important to me as a participant.

$\begin{array}{ccccc}\text { Strongly Agree } & \text { Agree } & \text { Disagree } & \begin{array}{c}\text { Strongly } \\ \text { Disagree }\end{array} & \text { Not Applicable } \\ 1 & 2 & 3 & 4 & 5\end{array}$

3 I wanted the opportumity to meet new people.

Strongly Agree Agree Disagree $\begin{gathered}\text { Strongly Not Applicable } \\ \text { Disagree }\end{gathered}$




$\begin{array}{lllll}1 & 2 & 3 & 4 & 5\end{array}$

\begin{tabular}{|c|c|c|c|c|c|}
\hline \multirow[t]{3}{*}{4} & \multicolumn{5}{|c|}{ I wanted to be a part of the WVU social system. } \\
\hline & Strongly Agree & Agree & Disagree & $\begin{array}{l}\text { Strongly } \\
\text { Disagree }\end{array}$ & Not Applicable \\
\hline & 1 & 2 & 3 & 4 & 5 \\
\hline \multirow[t]{3}{*}{5} & \multicolumn{5}{|c|}{ I wanted to party. } \\
\hline & Strongly Agree & Agree & Disagree & $\begin{array}{l}\text { Strongly } \\
\text { Disagree }\end{array}$ & Not Applicable \\
\hline & 1 & 2 & 3 & 4 & 5 \\
\hline
\end{tabular}

6 Many of my friends went to college.

$\begin{array}{ccccc}\text { Strongly Agree } & \text { Agree } & \text { Disagree } & \begin{array}{c}\text { Strongly } \\ \text { Disagree }\end{array} & \text { Not Applicable } \\ 1 & 2 & 3 & 4 & 5\end{array}$

7 The college experience intrigued me.

\begin{tabular}{ccccc} 
Strongly Agree & Agree & Disagree & $\begin{array}{c}\text { Strongly } \\
\text { Disagree }\end{array}$ & Not Applicable \\
1 & 2 & 3 & 4 & 5 \\
\hline
\end{tabular}

8 The overall atmosphere at WVU was welcoming.

$\begin{array}{ccccc}\text { Strongly Agree } & \text { Agree } & \text { Disagree } & \begin{array}{c}\text { Strongly } \\ \text { Disagree }\end{array} & \text { Not Applicable } \\ 1 & 2 & 3 & 4 & 5\end{array}$

9 A college degree was required to reach my career goals.

$\begin{array}{ccccc}\text { Strongly Agree } & \text { Agree } & \text { Disagree } & \begin{array}{c}\text { Strongly } \\ \text { Disagree }\end{array} & \text { Not Applicable } \\ 1 & 2 & 3 & 4 & 5\end{array}$


10 A college education/degree was a personal goal.

$\begin{array}{llll}\text { Strongly Agree Agree Disagree } & \begin{array}{c}\text { Strongly } \\ \text { Disagree }\end{array} & \text { Not Applicable } \\ & & & \end{array}$

Survey Page 1

\section{Motivations, Factors and Issues Concerning \\ Students at West Virginia University}

\section{Factors Influeneing Enrollment At West Virginia University}

Instructions: Using the following Likert scale, indicate the level of influence each item had on your decision to enroll at West Virginia University. Indicate your opinion by clicking on the button that that best correspond to your response: 1 - Strongly Agree, 2 -Agree, 3 - Disagree, 4 Strongly Disagree, or 5 - Not Applicable.

11 I wanted to be able to help others.

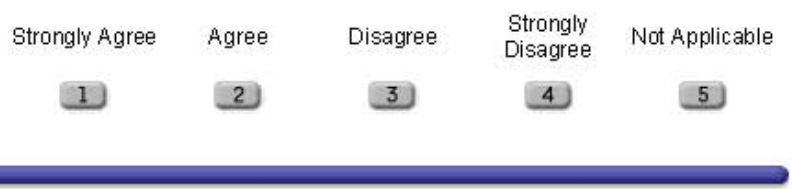

12 I wanted to serve as a role model.

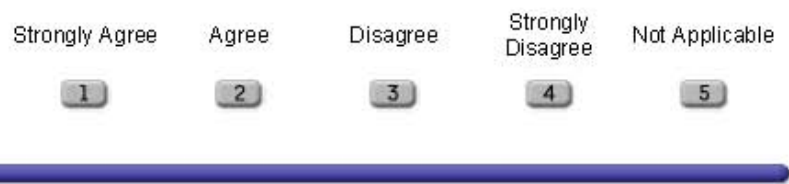

13 I wanted to try a different career path.

$\begin{array}{ccccc}\text { Strongly Agree } & \text { Agree } & \text { Disagree } & \begin{array}{c}\text { Strongly } \\ \text { Disagree }\end{array} & \text { Not Applicable } \\ 1 & 2 & 3 & 4 & 5\end{array}$


14 I was interested in expanding my knowledge in a particular subject area.

\begin{tabular}{ccccc}
\hline Strongly Agree & Agree & Disagree & $\begin{array}{c}\text { Strongly } \\
\text { Disagree }\end{array}$ & Not Applicable \\
1 & 2 & 3 & 4 & 5
\end{tabular}

15 There were many career opportunities associated with my degree.

\begin{tabular}{ccccc} 
Strongly Agree & Agree & Disagree & $\begin{array}{c}\text { Strongly } \\
\text { Disagree }\end{array}$ & Not Applicable \\
\hline 1 & 2 & 3 & 4 & 5
\end{tabular}

16 I have a drive to succeed.

\begin{tabular}{ccccc} 
Strongly Agree & Agree & Disagree & $\begin{array}{c}\text { Strongly } \\
\text { Disagree }\end{array}$ & Not Applicable \\
1 & 2 & 3 & 4 & 5 \\
\hline
\end{tabular}

17 I wanted to do something my parents did not have the opportunity to do.

\begin{tabular}{ccccc} 
Strongly Agree & Agree & Disagree & $\begin{array}{c}\text { Strongly } \\
\text { Disagree }\end{array}$ & Not Applicable \\
\hline 1 & 2 & 3 & 4 & 5 \\
\hline
\end{tabular}

18 I was determined to succeed in spite of others' perceptions.

$\begin{array}{ccccc}\text { Strongly Agree } & \text { Agree } & \text { Disagree } & \begin{array}{c}\text { Strongly } \\ \text { Disagree }\end{array} & \text { Not Applicable } \\ 1 & 2 & 3 & 4 & 5\end{array}$

19 My dreams and hopes centered on WVU.

\begin{tabular}{ccccc} 
Strongly Agree & Agree & Disagree & $\begin{array}{c}\text { Strongly } \\
\text { Disagree }\end{array}$ & Not Applicable \\
1 & 2 & 3 & 4 & 5 \\
\hline
\end{tabular}


20 It was tradition in my family to attend college.

Strongly Agree Agree Disagree $\begin{gathered}\text { Strongly } \\ \text { Disagree }\end{gathered}$

Survey Page 2

\section{Motivations, Factors and Issues Concerning}

Students at West Virginia University

\section{- \\ Factors Influeneing Enrollment At West Virginia University}

Instructions: Using the following Likert scale, indicate the level of influence each item had on your decision to enroll at West Virginia University. Indicate your opinion by clicking on the button that that best correspond to your response: 1 - Strongly Agree, 2 -Agree, 3 - Disagree, 4 Strongly Disagree, or 5 - Not Applicable.

21 My family encouraged me to attend college.

$\begin{array}{ccccc}\text { Strongly Agree } & \text { Agree } & \text { Disagree } & \begin{array}{c}\text { Strongly } \\ \text { Disagree }\end{array} & \text { Not Applicable } \\ 1 & 2 & 3 & 4 & 5\end{array}$

22 My grandparents encouraged me to attend college.

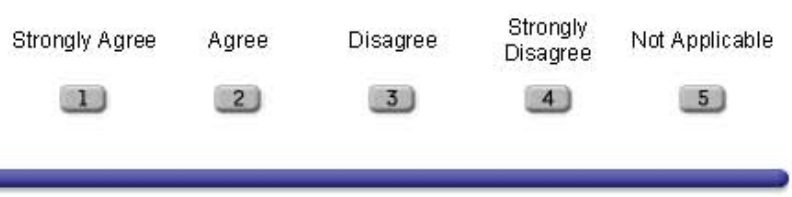

23 My high school teachers encouraged me to attend college.

$$
\text { Strongly Agree Agree Disagree } \quad \begin{gathered}
\text { Strongly } \\
\text { Disagree }
\end{gathered} \quad \text { Not Applicable }
$$


$1 \quad 2 \quad 3 \quad 4 \quad 5$

\begin{tabular}{ccccc}
24 & A college education would give me financial security. \\
& & & & \\
Strongly Agree & Agree & Disagree & $\begin{array}{c}\text { Strongly } \\
\text { Disagree }\end{array}$ & Not Applicable \\
1 & 2 & 3 & 4 & 5 \\
\hline
\end{tabular}

25 A college education would give me the opportumity to make more money.

\begin{tabular}{ccccc}
\hline Strongly Agree & Agree & Disagree & $\begin{array}{c}\text { Strongly } \\
\text { Disagree }\end{array}$ & Not Applicable \\
1 & 2 & 3 & 4 & 5 \\
\hline
\end{tabular}

26 A college education would allow me to support a family.

$\begin{array}{ccccc}\text { Strongly Agree } & \text { Agree } & \text { Disagree } & \begin{array}{c}\text { Strongly } \\ \text { Disagree }\end{array} & \text { Not Applicable } \\ 1 & 2 & 3 & 4 & 5\end{array}$

27 The current economic situation promoted my decision to attend college.

\begin{tabular}{ccccc}
\hline Strongly Agree & Agree & Disagree & $\begin{array}{c}\text { Strongly } \\
\text { Disagree }\end{array}$ & Not Applicable \\
1 & 2 & 3 & 4 & 5 \\
\hline
\end{tabular}

28 Scholarships motivated me to attend wVu.

$\begin{array}{ccccc}\text { Strongly Agree } & \text { Agree } & \text { Disagree } & \begin{array}{c}\text { Strongly } \\ \text { Disagree }\end{array} & \text { Not Applicable } \\ 1 & 2 & 3 & 4 & 5\end{array}$

29 A college education would improve my feelings of self worth.

\begin{tabular}{ccccc}
\hline Strongly Agree & Agree & Disagree & $\begin{array}{c}\text { Strongly } \\
\text { Disagree }\end{array}$ & Not Applicable \\
1 & 2 & 3 & 4 & 5
\end{tabular}


30 Attending college allowed me to delay being a grown-up.

\begin{tabular}{ccccc} 
Strongly Agree & Agree & Disagree & $\begin{array}{c}\text { Strongly } \\
\text { Disagree }\end{array}$ & Not Applicable \\
1 & 2 & 3 & 4 & 5 \\
\hline
\end{tabular}

$\begin{array}{lllll}1 & 2 & 3 & 4 & 5\end{array}$

31 College was the first step in gaining personal independence.

Strongly Agree Agree Disagree $\begin{gathered}\text { Strongly } \\ \text { Disagree }\end{gathered}$

\section{Motivations, Factors and Issues Concerning Students at West Virginia University}

\section{Faetors Influeneing Your Decision to Stay at WVU}

Instructions: Using the following Likert scale, indicate the level of influence each item had on your decision to remain a student at West Virginia University. Indicate your opinion by clicking on the button that that best correspond to your response: 1 - Strongly Agree, 2 - Agree, 3 Disagree, 4 -Strongly Disagree, or 5-Not Applicable.

32 Personal determination/motivation.

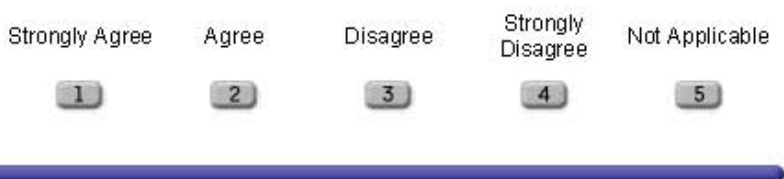

33 I fear change.

Strongly Agree Agree Disagree $\quad \begin{gathered}\text { Strongly } \\ \text { Disagree }\end{gathered} \quad$ Not Applicable




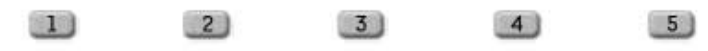

Strongly Agree Agr

\begin{tabular}{|c|c|c|c|c|}
\hline 1 & 2 & 3 & 4 & 5 \\
\hline
\end{tabular}

35 Without college, I would have nothing to do with my life.

Strongly Agree

1
Agree

2
Disagree

3
Strongly Disagre

4

Not Applicable

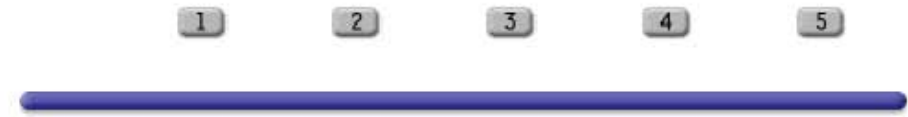

36 My career goal(s).

$\begin{array}{ccccc}\text { Strongly Agree } & \text { Agree } & \text { Disagree } & \begin{array}{c}\text { Strongly } \\ \text { Disagree }\end{array} & \text { Not Applicable } \\ 1 & 2 & 3 & 4 & 5\end{array}$

37 Employment opportunities after graduation.

\begin{tabular}{ccccc} 
Strongly Agree & Agree & Disagree & $\begin{array}{c}\text { Strongly } \\
\text { Disagree }\end{array}$ & Not Applicable \\
1 & 2 & 3 & 4 & 5 \\
\hline
\end{tabular}

38 The opportumity to learn/expand my knowledge.

$\begin{array}{ccccc}\text { Strongly Agree } & \text { Agree } & \text { Disagree } & \begin{array}{c}\text { Strongly } \\ \text { Disagree }\end{array} & \text { Not Applicable } \\ 1 & 2 & 3 & 4 & 5\end{array}$

39 Courses in my major are very entertaining.

$\begin{array}{ccccc}\text { Strongly Agree } & \text { Agree } & \text { Disagree } & \begin{array}{c}\text { Strongly } \\ \text { Disagree }\end{array} & \text { Not Applicable } \\ 1 & 2 & 3 & 4 & 5\end{array}$


40 The availability of one-on-one help in the classroom.

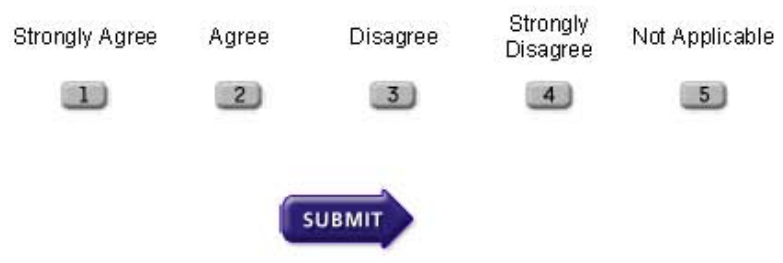

Survey Page 4

\section{Motivations, Factors and Issues Concerning}

Students at West Virginia University

\section{Factors Influeneing Your Decision to Stay at WvU}

Instructions: Using the following Likert scale, indicate the level of influence each item had on your decision to remain a student at West

Virginia University. Indicate your opinion by clicking on the button

that that best correspond to your response: 1 - Strongly Agree, 2 - Agree, 3 -

Disagree, 4 -Strongly Dis agree, or 5 - Not Applicable.

41 Encouragement from my friends

Strongly Agree Agree Disagree $\begin{gathered}\text { Strongly } \\ \text { Disagree }\end{gathered} \quad$ Not Applicable

$12 \quad 2 \quad 4 \quad 5 \quad 5$

42 To make my parents proud

$\begin{array}{ccccc}\text { Strongly Agree } & \text { Agree } & \text { Disagree } & \begin{array}{c}\text { Strongly } \\ \text { Disagree }\end{array} & \text { Not Applicable } \\ 1 & 2 & 3 & 4 & 5\end{array}$

43 My parents' insistence

$\begin{array}{ccccc}\text { Strongly Agree } & \text { Agree } & \text { Disagree } & \begin{array}{c}\text { Strongly } \\ \text { Disagree }\end{array} & \text { Not Applicable } \\ 1 & 2 & 3 & 4 & 5\end{array}$


44 My 'significant other's' encouragement

$\begin{array}{ccccc}\text { Strongly Agree } & \text { Agree } & \text { Disagree } & \begin{array}{c}\text { Strongly } \\ \text { Disagree }\end{array} & \text { Not Applicable } \\ 1 & 2 & 3 & 4 & 5\end{array}$

45 My family's encouragement

$\begin{array}{ccccc}\text { Strongly Agree } & \text { Agree } & \text { Disagree } & \begin{array}{c}\text { Strongly } \\ \text { Disagree }\end{array} & \text { Not Applicable } \\ 1 & 2 & 3 & 4 & 5\end{array}$

46 The current economic situation

\begin{tabular}{ccccc} 
Strongly Agree & Agree & Disagree & $\begin{array}{c}\text { Strongly } \\
\text { Disagree }\end{array}$ & Not Applicable \\
1 & 2 & 3 & 4 & 5 \\
\hline
\end{tabular}

47 The availability of financial aid

$\begin{array}{ccccc}\text { Strongly Agree } & \text { Agree } & \text { Disagree } & \begin{array}{c}\text { Strongly } \\ \text { Disagree }\end{array} & \text { Not Applicable } \\ 1 & 2 & 3 & 4 & 5\end{array}$

48 Parental funding

\begin{tabular}{ccccc} 
Strongly Agree & Agree & Disagree & $\begin{array}{c}\text { Strongly } \\
\text { Disagree }\end{array}$ & Not Applicable \\
1 & 2 & 3 & 4 & 5 \\
\hline
\end{tabular}

49 The availability of scholarships

\begin{tabular}{ccccc} 
Strongly Agree & Agree & Disagree & $\begin{array}{c}\text { Strongly } \\
\text { Disagree }\end{array}$ & Not Applicable \\
1 & 2 & 3 & 4 & 5 \\
\hline
\end{tabular}




\section{Motivations, Factors and Issues Concerning Students at West Virginia University}

\section{Factors Influeneing Your Decision to Stay at WVU}

Instructions: Using the following Likert scale, indicate the level of influence each item had on your decision to remain a student at West

Virginia University. Indicate your opinion by clicking on the button

that that best correspond to your response: 1 - Strongly Agree, 2 - Agree, 3 -

Disagree, 4 - Strongly Dis agree, or 5 -Not Applicable.

50 The location of WVU

Strongly Agree

Agree

Disagree

Strongly

Disagree

Not Applicable

1

2

3

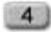

5

51 My major is not available in my home state

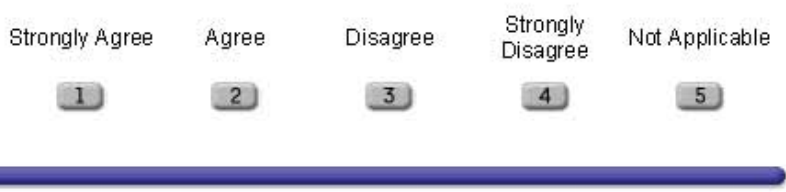

52 The resources available to students (computers, tutors, etc)

\begin{tabular}{ccccc} 
Strongly Agree & Agree & Disagree & $\begin{array}{c}\text { Strongly } \\
\text { Disagree }\end{array}$ & Not Applicable \\
1 & 2 & 3 & 4 & 5 \\
\hline
\end{tabular}

53 The size of WVu

\begin{tabular}{ccccc} 
Strongly Agree & Agree & Disagree & $\begin{array}{c}\text { Strongly } \\
\text { Disagree }\end{array}$ & Not Applicable \\
1 & 2 & 3 & 4 & 5 \\
\hline
\end{tabular}


54 The facilities available to students
Strongly Agree
Agree
Disagree
Strongly
Disagree
Not Applicable
1
2
3
4
5

55 WVU has knowledgeable faculty/professors

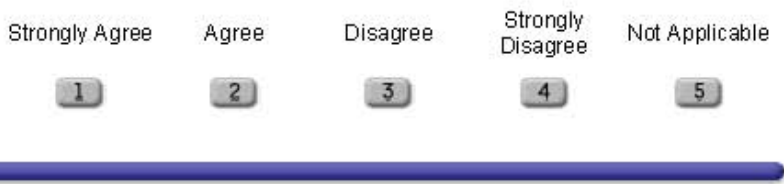

56 WVU offers many opportumities for students to become involved

\begin{tabular}{ccccc} 
Strongly Agree & Agree & Disagree & $\begin{array}{c}\text { Strongly } \\
\text { Disagree }\end{array}$ & Not Applicable \\
\hline 1 & 2 & 3 & 4 & 5 \\
\hline
\end{tabular}

57 My friends are here

Strongly Agree Agree

Disagree

Strongly

Not Applicable

1

2

3

4

5

58 Athletic events

$\begin{array}{llll}\text { Strongly Agree Agree } & \text { Disagree } & \begin{array}{c}\text { Strongly } \\ \text { Disagree }\end{array} & \text { Not Applicable } \\ & 2 & 4 & 5 \\ \text { SUBMIT } & & \end{array}$

Survey Page 6

\section{Motivations, Factors and Issues Concerning Students at West Virginia University}




\section{Factors Influeneing Your Decision to Stay at WVU}

Instructions: Using the following Likert scale, indicate the level of influence each item had on your decision to remain a student at West Virginia University. Indicate your opinion by clicking on the button that that best correspond to your response: 1 - Strongly Agree, 2 - Agree, 3 Disagree, 4 - Strongly Disagree, or 5 -Not Applicable.

59 I enjoy the WrU atmosphere

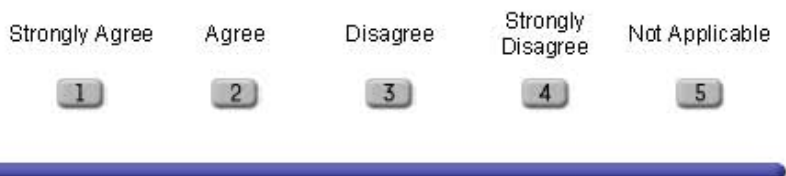

60 I feel at home at WVu

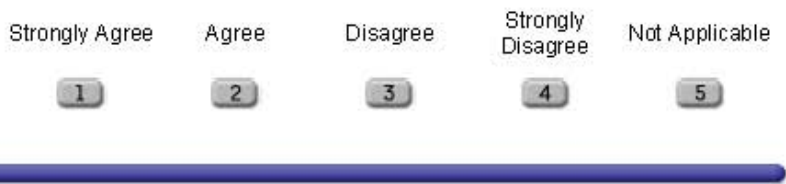

61 Parties

\begin{tabular}{|ccccc} 
Strongly Agree & Agree & Disagree & $\begin{array}{c}\text { Strongly } \\
\text { Disagree }\end{array}$ & Not Applicable \\
1 & 2 & 3 & 4 & 5 \\
\hline
\end{tabular}

62 Social life

$\begin{array}{ccccc}\text { Strongly Agree } & \text { Agree } & \text { Disagree } & \begin{array}{c}\text { Strongly } \\ \text { Disagree }\end{array} & \text { Not Applicable } \\ 1 & 2 & 3 & 4 & 5\end{array}$

63 Friendly and Personable professors

\begin{tabular}{ccccc} 
Strongly Agree & Agree & Disagree & $\begin{array}{c}\text { Strongly } \\
\text { Disagree }\end{array}$ & Not Applicable \\
1 & 2 & 3 & 4 & 5 \\
\hline
\end{tabular}


64 Have you considered leaving the University?

YES NO

Factors Influencing Your Consideration to Leave at WVU

Instructions: Many students have second thoughts about their selection of a college and/or their career goals. Were you one of these individuals? Indicate your opinion by clicking on the button that that best correspond to your response: 1 - Strongly Agree, 2 - Agree, 3 - Disagree, 4 - Strongly Disagree, or 5 - Not Applicable.

65 Careers in my major did not interest me

$\begin{array}{cccc}\text { Strongly Agree Agree } & \text { Disagree } & \begin{array}{c}\text { Strongly } \\ \text { Disagree }\end{array} & \text { Not Applicable } \\ & & & \\ & & & \end{array}$

Motivations, Factors and Issues Concerning

Students at West Virginia University

\section{Factors Influeneing Your Consideration to Leave at WVU}

Instructions: Many students have second thoughts about their selection of a college and/or their career goals. Were you one of these individuals? Indicate your opinion by clicking on the button that that best correspond to your response: 1 - Strongly Agree, 2 - Agree, 3 - Disagree, 4 - Strongly Disagree, or 5 - Not Applicable.

66 Classes did not pertain to my interests

Strongly Agree Agree Disagree $\quad \begin{gathered}\text { Strongly } \\ \text { Disagree }\end{gathered}$ Not Applicable


$\begin{array}{lllll}1 & 2 & 3 & 4 & 5\end{array}$

\begin{tabular}{|c|c|c|c|c|c|}
\hline \multirow[t]{3}{*}{67} & I didn't need & e degree & & & \\
\hline & Strongly Agree & Agree & Disagree & $\begin{array}{l}\text { Strongly } \\
\text { Disagree }\end{array}$ & Not Applicable \\
\hline & 1 & 2 & 3 & 4 & 5 \\
\hline
\end{tabular}

68 Limited career options

$\begin{array}{llccc}\text { Strongly Agree } & \text { Agree } & \text { Disagree } & \begin{array}{c}\text { Strongly } \\ \text { Disagree }\end{array} & \text { Not Applicable } \\ 1 & 2 & 3 & 4 & 5\end{array}$

69 Roommates

$\begin{array}{ccccc}\text { Strongly Agree } & \text { Agree } & \text { Disagree } & \begin{array}{c}\text { Strongly } \\ \text { Disagree }\end{array} & \text { Not Applicable } \\ 1 & 2 & 3 & 4 & 5\end{array}$

70 Rude students

\begin{tabular}{ccccc} 
Strongly Agree & Agree & Disagree & $\begin{array}{c}\text { Strongly } \\
\text { Disagree }\end{array}$ & Not Applicable \\
1 & 2 & 3 & 4 & 5 \\
\hline
\end{tabular}

71 Inability to do school and work full-time

$\begin{array}{ccccc}\text { Strongly Agree } & \text { Agree } & \text { Disagree } & \begin{array}{c}\text { Strongly } \\ \text { Disagree }\end{array} & \text { Not Applicable } \\ 1 & 2 & 3 & 4 & 5\end{array}$

72 Required too much studying

$\begin{array}{ccccc}\text { Strongly Agree } & \text { Agree } & \text { Disagree } & \begin{array}{c}\text { Strongly } \\ \text { Disagree }\end{array} & \text { Not Applicable } \\ 1 & 2 & 3 & 4 & 5\end{array}$


73 School work was too hard

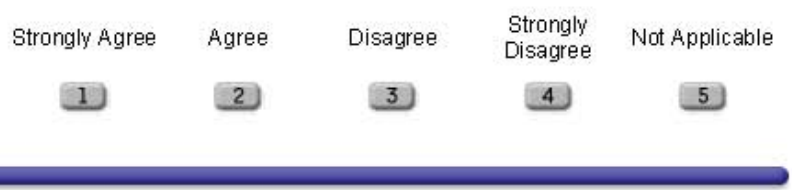

74 I became discouraged

Strongly Agree Agree Disagree

Strongly

Not Applicable

1

2

3

4.

5.

\section{Motivations, Factors and Issues Concerning}

Students at West Virginia University

Factors Influencing Your Consideration to Leave at WVU

Instructions: Many students have second thoughts about their selection of a college and/or their career goals. Were you one of these individuals? Indicate your opinion by clicking on the button that that best correspond to your response: 1 - Strongly Agree, 2 - Agree, 3 - Disagree, 4 - Strongly Disagree, or 5 - Not Applicable.

75 I was burnt out

$\begin{array}{ccccc}\text { Strongly Agree } & \text { Agree } & \text { Disagree } & \begin{array}{c}\text { Strongly } \\ \text { Disagree }\end{array} & \text { Not Applicable } \\ 1 & 2 & 3 & 4 & 5\end{array}$

76 I was overwhelmed

$\begin{array}{ccccc}\text { Strongly Agree } & \text { Agree } & \text { Disagree } & \begin{array}{c}\text { Strongly } \\ \text { Disagree }\end{array} & \text { Not Applicable } \\ 1 & 2 & 3 & 4 & 5\end{array}$




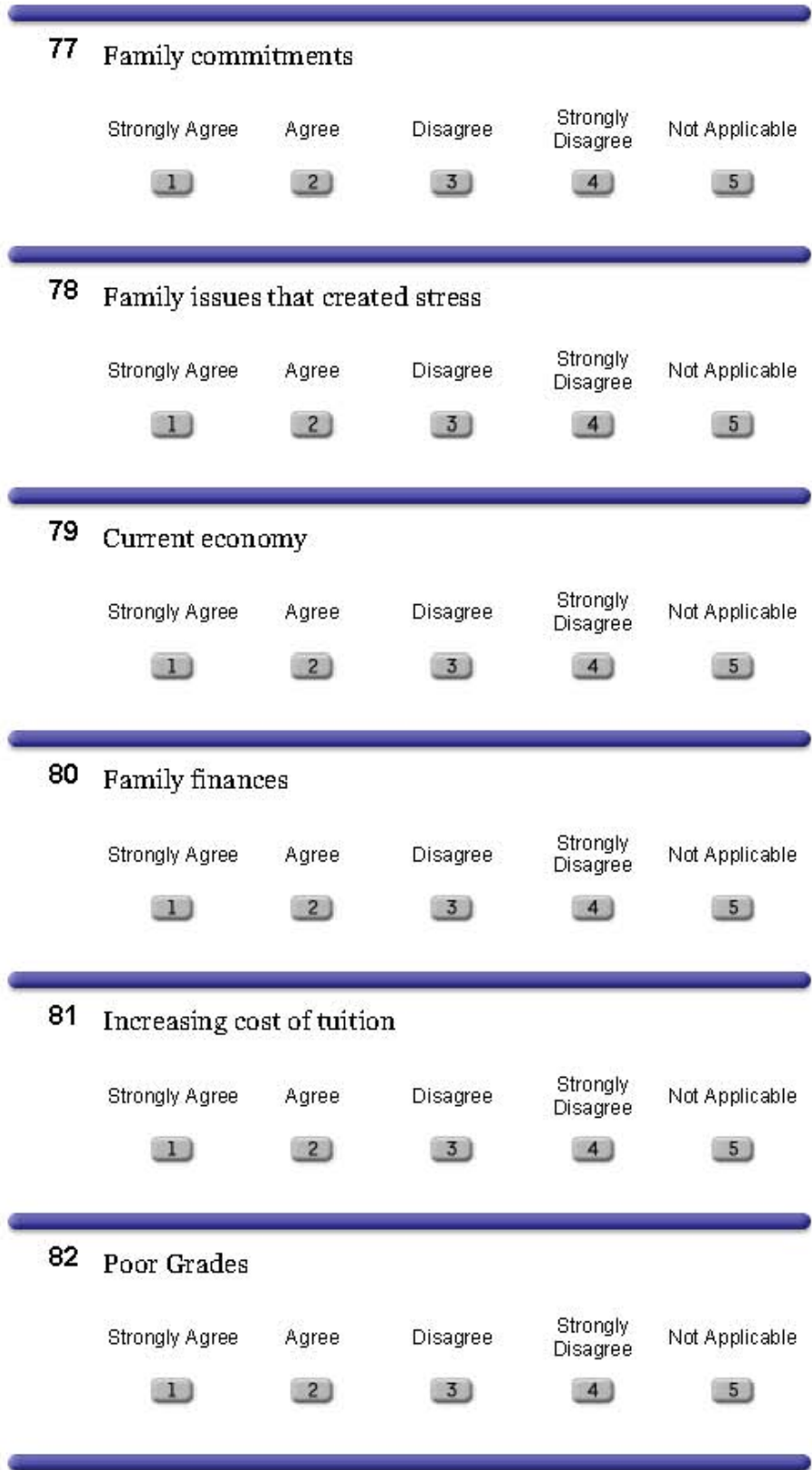

83

I felt like I wasn't making progress 


$\begin{array}{ccccc}\text { Strongly Agree } & \text { Agree } & \text { Disagree } & \begin{array}{c}\text { Strongly } \\ \text { Disagree }\end{array} & \text { Not Applicable } \\ 1 & 2 & 3 & 4 & 5\end{array}$

\section{Motivations, Factors and Issues Concerning}

Students at West Virginia University

Factors Influeneing Your Consideration to Leave at WVU

Instructions: Many students have second thoughts about their selection of a college and/or their career goals. Were you one of these individuals? Indicate your opinion by clicking on the button that that best correspond to your response: 1 - Strongly Agree, 2 - Agree, 3 - Disagree, 4 - Strongly Disagree, or 5 - Not Applicable.

84 I didn't like being away from my family

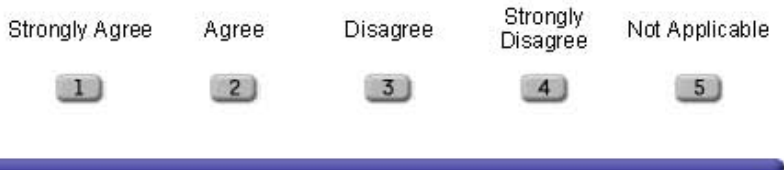

85 I felt alone

$\begin{array}{ccccc}\text { Strongly Agree } & \text { Agree } & \text { Disagree } & \begin{array}{c}\text { Strongly } \\ \text { Disagree }\end{array} & \text { Not Applicable } \\ 1 & 2 & 3 & 4 & 5\end{array}$

86 Daily challenges that faced me

$\begin{array}{ccccc}\text { Strongly Agree } & \text { Agree } & \text { Disagree } & \begin{array}{c}\text { Strongly } \\ \text { Disagree }\end{array} & \text { Not Applicable } \\ 1 & 2 & 3 & 4 & 5\end{array}$




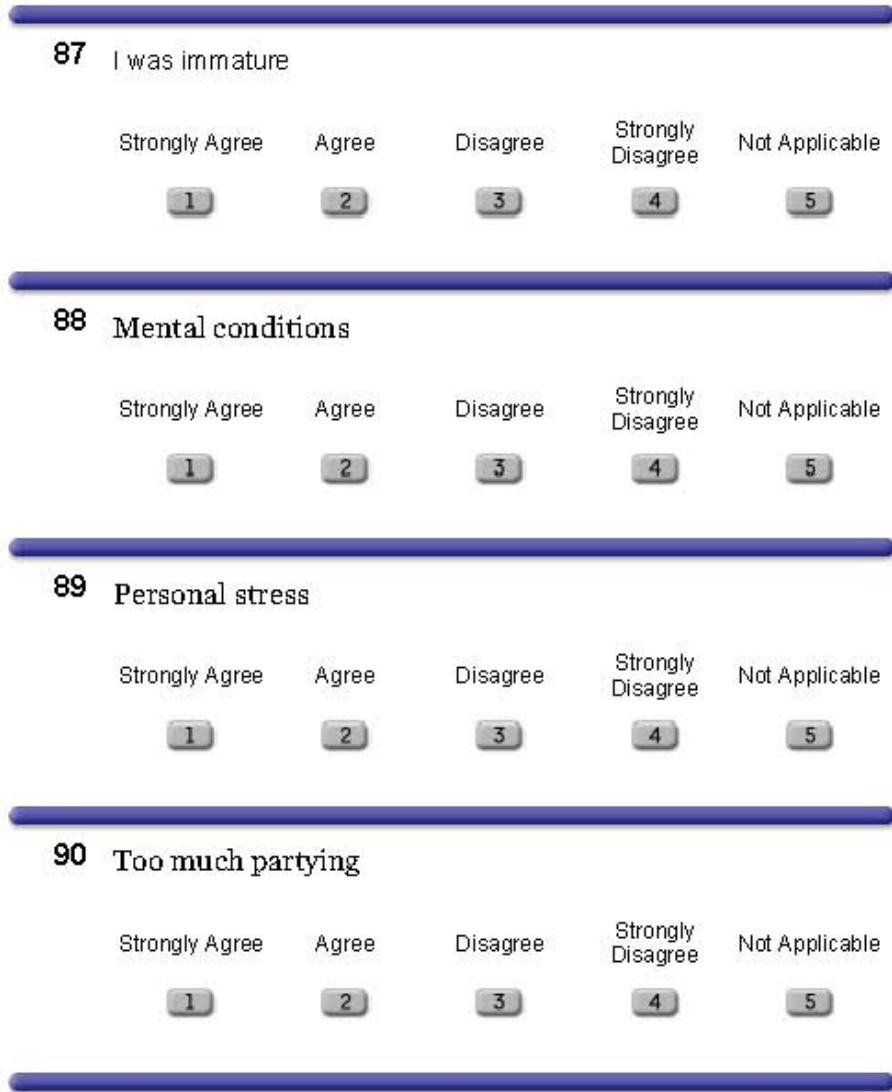

91 Frustration with instructors

\begin{tabular}{ccccc} 
Strongly Agree & Agree & Disagree & $\begin{array}{c}\text { Strongly } \\
\text { Disagree }\end{array}$ & Not Applicable \\
1 & 2 & 3 & 4 & 5 \\
\hline
\end{tabular}

92 Professors weren't willing to help

$\begin{array}{ccccc}\text { Strongly Agree } & \text { Agree } & \text { Disagree } & \begin{array}{c}\text { Strongly } \\ \text { Disagree }\end{array} & \text { Not Applicable } \\ 1 & 2 & 3 & 4 & 5\end{array}$




\section{Motivations, Factors and Issues Concerning Students at West Virginia University}

Factors Influeneing Your Consideration to Leave at WVU

Instructions: Many students have second thoughts about their selection of a college and/or their career goals. Were you one of these individuals? Indicate your opinion by clicking on the button that that best correspond to your response: 1 - Strongly Agree, 2 - Agree, 3 - Disagree, 4 - Strongly Disagree, or 5 - Not Applicable.

93 Rude professors

Strongly Agree Agree Disagree $\begin{gathered}\text { Strongly } \\ \text { Disagree }\end{gathered}$ Not Applicable

(1) 2 (2) 4

4

94 Lack of self control

$\begin{array}{ccccc}\text { Strongly Agree } & \text { Agree } & \text { Disagree } & \begin{array}{c}\text { Strongly } \\ \text { Disagree }\end{array} & \text { Not Applicable } \\ 1 & 2 & 3 & 4 & 5\end{array}$

\section{Recommended Changes at WVU}

Instructions: Using the following Likert scale, indicate the changes you would recommend at WV . Indicate your opinion by clicking on the button that that best correspond to your response: 1 - Strongly Agree, 2 - Agree, 3 Disagree, 4 -Strongly Dis agree, or 5 -Not Applicable.

95 Better freshmen intro classes

$\begin{array}{ccccc}\text { Strongly Agree } & \text { Agree } & \text { Disagree } & \begin{array}{c}\text { Strongly } \\ \text { Disagree }\end{array} & \text { Not Applicable } \\ 1 & 2 & 3 & 4 & 5\end{array}$


96 Increase the availability of classes
Strongly Agree
Agree
Disagree
Disagree
Not Applicable
1 (1)
2
3
4
5

97 Increase the number of online classes

Strongly Agree

Agree

Disagree

Strongly

Not Applicable

1

2

3

4

5

98 Less complicated class scheduling

Strongly Agree Agree Disagree Strongly

\begin{tabular}{lllll} 
Strongly Agree & Agree & Disagree & $\begin{array}{c}\text { Strongly } \\
\text { Disagree }\end{array}$ & Not Applicable \\
1 & 2 & 3 & 4 & 5 \\
\hline
\end{tabular}

Not Applicable

99 Less core curriculum
Strongly Agree
Agree
Disagree
Strongly
Disagree
Not Applicable
1.
2
3
4
5

\section{Motivations, Factors and Issues Concerning}

Students at West Virginia University

\section{Recommended Changes at WvU}

Instruetions: Using the following Likert scale, indicate the changes you would recommend at WVU. Indicate your opinion by clicking on the button that that best correspond to your response: 1 - Strongly Agree, 2 - Agree, 3 - Disagree, 4 - Strongly Disagree, or 5

- Not Applicable. 
100 More transitional support for incoming students

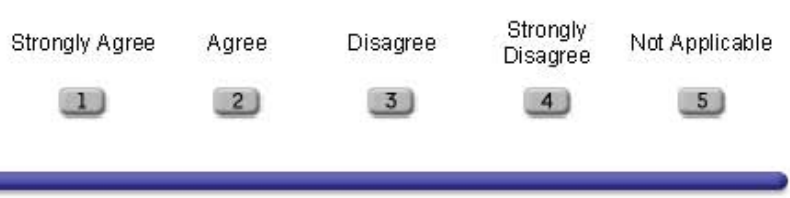

101 Smaller classes

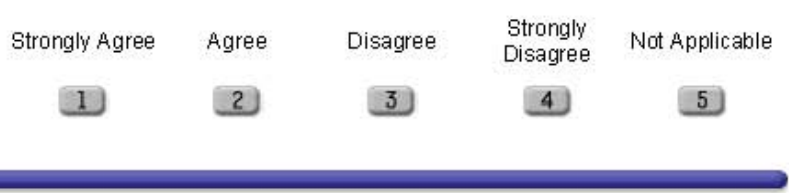

102 Teach classes on multiple campuses

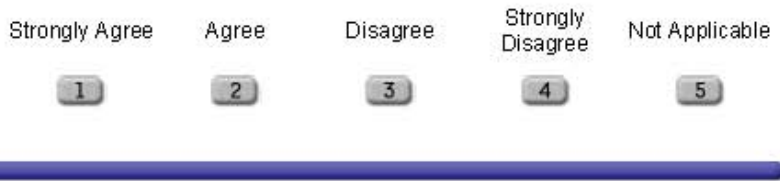

103 Affordable housing

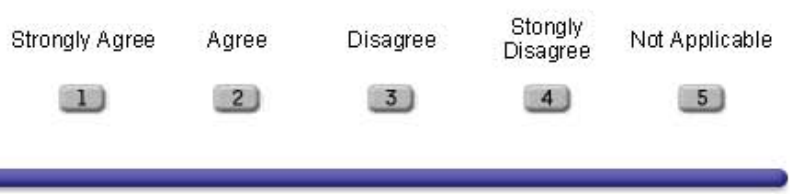

104 Increase financial aid and grants

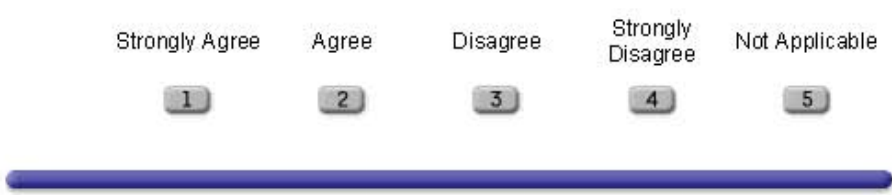

105 Opportumity to opt out of certain fees (rec center, football)

\begin{tabular}{ccccc} 
Strongly Agree & Agree & Disagree & $\begin{array}{c}\text { Strongly } \\
\text { Disagree }\end{array}$ & Not Applicable \\
1 & 2 & 3 & 4 & 5 \\
\hline
\end{tabular}

106

Tuition costs 


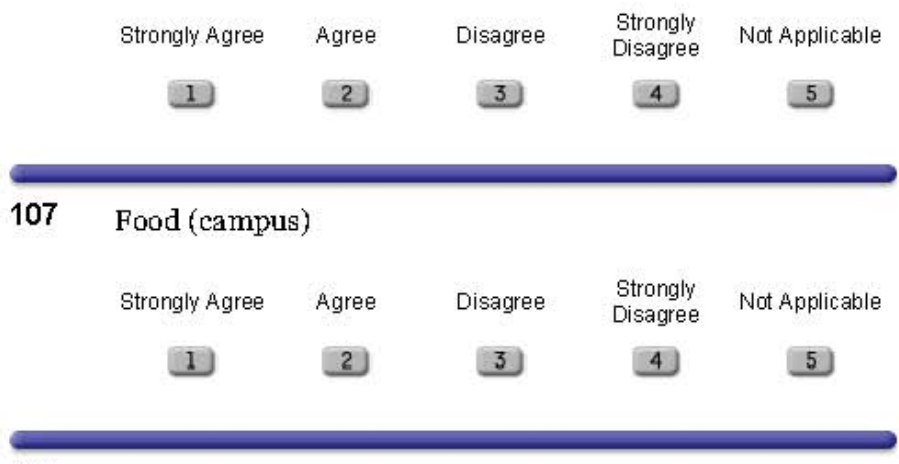

108 Flexible meal plan options for the Moutainlair

$\begin{array}{cccc}\text { Strongly Agree Agree } & \text { Disagree } & \begin{array}{c}\text { Strongly } \\ \text { Disagree }\end{array} & \text { Not Applicable } \\ & & & \end{array}$

\section{Motivations, Factors and Issues Concerning Students at West Virginia University}

\section{Recommended Changes at wru}

Instructions: Using the following Likert scale, indicate the changes you would recommend at WVU. Indicate your opinion by clicking on the button that that best correspond to your response: 1 - Strongly Agree, 2 - Agree, 3 - Disagree, 4 - Strongly Disagree, or 5 - Not Applicable.

109 Reduce hostilities in the departments

$\begin{array}{ccccc}\text { Strongly Agree } & \text { Agree } & \text { Disagree } & \begin{array}{c}\text { Strongly } \\ \text { Disagree }\end{array} & \text { Not Applicable } \\ 1 & 2 & 3 & 4 & 5\end{array}$


110 Improve the relationship between professor and student

$$
\begin{array}{ccccc}
\text { Strongly Agree } & \text { Agree } & \text { Disagree } & \begin{array}{c}
\text { Strongly } \\
\text { Disagree }
\end{array} & \text { Not Applicable } \\
1 & 2 & 3 & 4 & 5
\end{array}
$$

111 Reduce political atmosphere in the university management

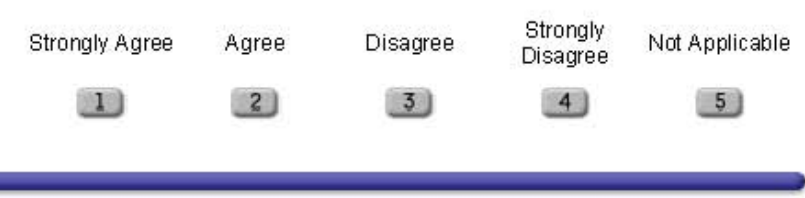

112 Remove Barnes and Noble from Campus

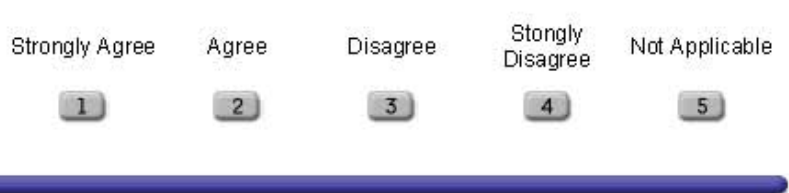

113 Improve eCampus

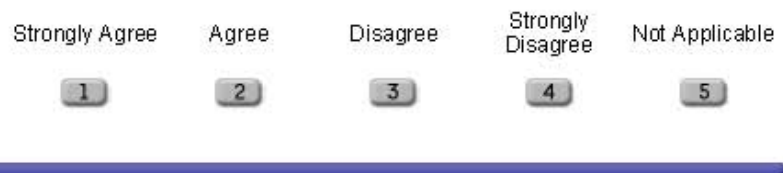

114 Open Evansdale library earlier

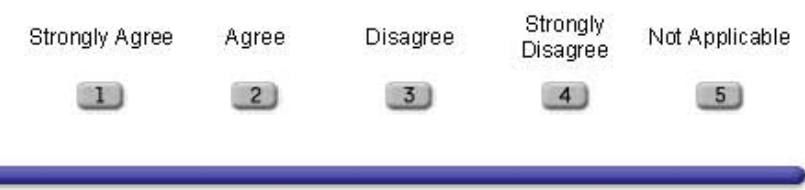

115 Improve STAR

$\begin{array}{ccccc}\text { Strongly Agree } & \text { Agree } & \text { Disagree } & \begin{array}{c}\text { Strongly } \\ \text { Disagree }\end{array} & \text { Not Applicable } \\ 1 & 2 & 3 & 4 & 5\end{array}$

116 Improve the mail system

Strongly Agree Agree Disagree $\quad \begin{gathered}\text { Strongly } \\ \text { Disagree }\end{gathered} \quad$ Not Applicable




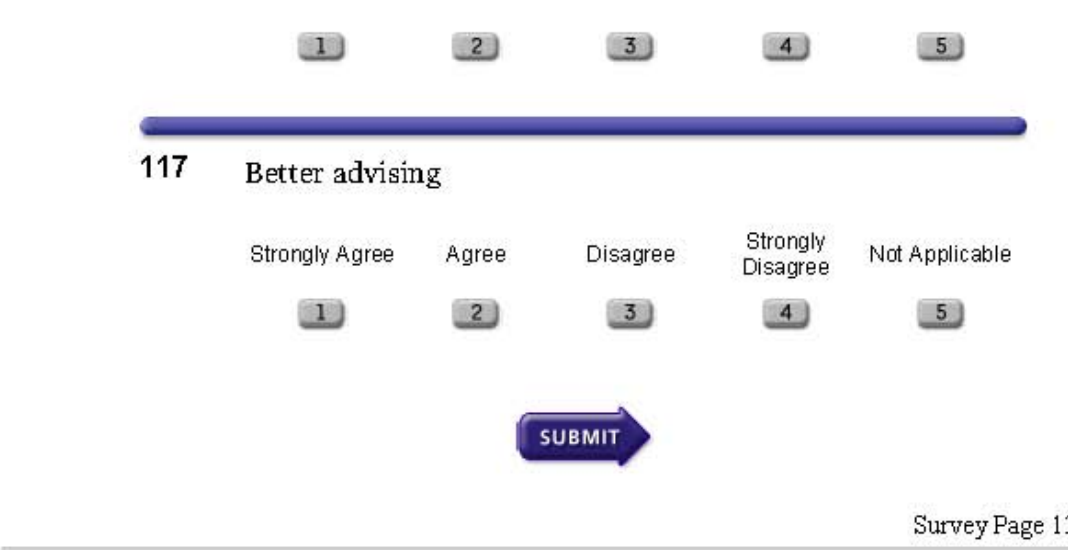

\section{Motivations, Factors and Issues Concerning} Students at West Virginia University

\section{Recommended Changes at WvU}

Instruetions: Using the following Likert scale, indicate the changes you would recommend at WVU. Indicate your opinion by clicking on the button that that best correspond to your response: 1 - Strongly Agree, 2 - Agree, 3 - Disagree, 4 - Strongly Disagree, or 5

- Not Applicable.

118 Improve professor/student ratio

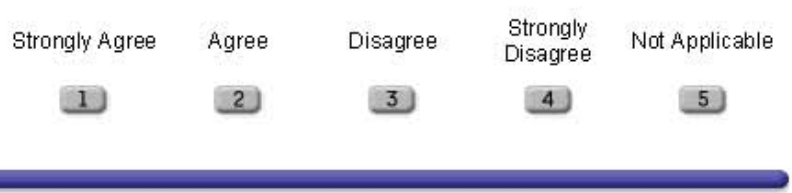

119 Increase eCampus use

$\begin{array}{ccccc}\text { Strongly Agree } & \text { Agree } & \text { Disagree } & \begin{array}{c}\text { Strongly } \\ \text { Disagree }\end{array} & \text { Not Applicable } \\ 1 & 2 & 3 & 4 & 5\end{array}$

120 Improve commuter accommodations

Strongly Agree Agree Disagree $\begin{gathered}\text { Strongly } \\ \text { Disagree }\end{gathered} \quad$ Not Applicable




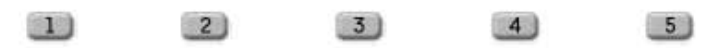

121 Improve traffic flow

$\begin{array}{ccccc}\text { Strongly Agree } & \text { Agree } & \text { Disagree } & \begin{array}{c}\text { Stongly } \\ \text { Disagree }\end{array} & \text { Not Applicable } \\ 1 & 2 & 3 & 4 & 5\end{array}$

122 Improve walkways

\begin{tabular}{ccccc} 
Strongly Agree & Agree & Disagree & $\begin{array}{c}\text { Strongly } \\
\text { Disagree }\end{array}$ & Not Applicable \\
1 & 2 & 3 & 4 & 5 \\
\hline
\end{tabular}

123 Increase available parking

\begin{tabular}{ccccc} 
Strongly Agree & Agree & Disagree & $\begin{array}{c}\text { Strongly } \\
\text { Disagree }\end{array}$ & Not Applicable \\
1 & 2 & 3 & 4 & 5 \\
\hline
\end{tabular}

124 Improve PRT

$\begin{array}{ccccc}\text { Strongly Agree } & \text { Agree } & \text { Disagree } & \begin{array}{c}\text { Strongly } \\ \text { Disagree }\end{array} & \text { Not Applicable } \\ 1 & 2 & 3 & 4 & 5\end{array}$

125 Provide safer walk from Coliseum to Evansdale Campus

\begin{tabular}{ccccc} 
Strongly Agree & Agree & Disagree & $\begin{array}{c}\text { Strongly } \\
\text { Disagree }\end{array}$ & Not Applicable \\
1 & 2 & 3 & 4 & 5 \\
\hline
\end{tabular}

Please Continue to the next page 


\section{Motivations, Factors and Issues Concerning Students at West Virginia University}




\section{Challenges Faced at WvU}

Instruetions: Using the following Likert scale, indicate the challenges you faced at WVU. Indicate your opinion by clicking on the button that that best correspond to your response: 1 - Strongly Agree, 2 - Agree, 3 - Disagree, 4 - Strongly Disagree, or 5 - Not Applicable.

126 Poor study skills

Strongly Agree Agr

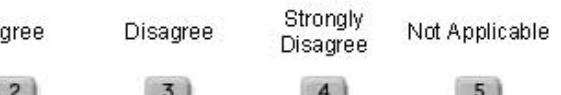

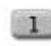

2

3

4

5

127 Bad advising

Strongly Agree

Agree

Disagree

Strongly

Not Applicable

1

2

3

4

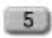

128

Classes were too difficult
Strongly Agree
Agree
Disagree
Strongly
Disagree
Not Applicable
1
2
3
4
5

129 Teachers made it difficult to focus

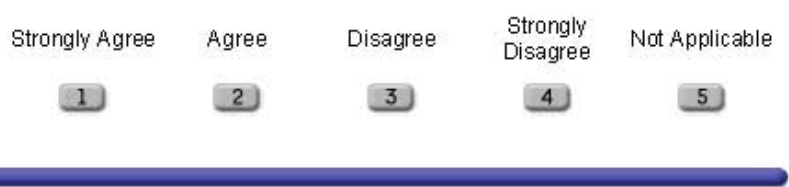

130

Difficult living situation

Strongly Agree Agree Disagree $\begin{gathered}\text { Strongly Not Applicable } \\ \text { Disagree }\end{gathered}$




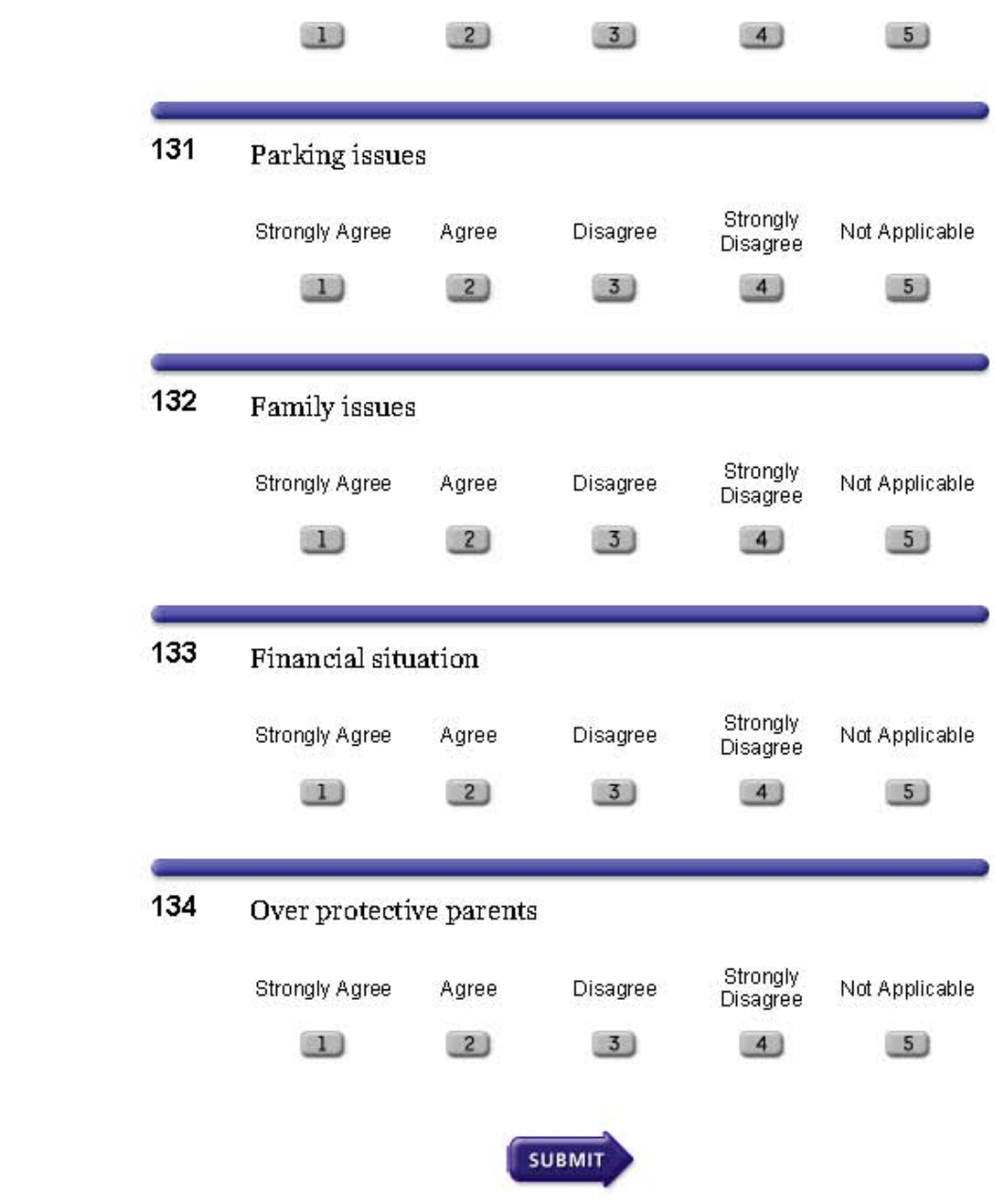

Survey Page 15

\section{Motivations, Factors and Issues Concerning}

Students at West Virginia University

\section{Challenges Faced at WvU}


Instruetions: Using the following Likert scale, indicate the challenges you faced at WVU. Indicate your opinion by clicking on the button that that best correspond to your response: 1 - Strongly Agree, 2 - Agree, 3 - Disagree, 4 - Strongly Disagree, or 5 - Not Applicable.

135

Emotional issues

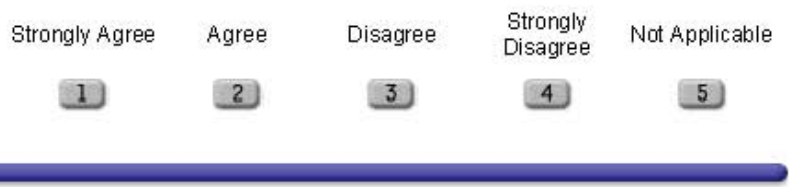

136 I felt alone

Strongly Agree

Agree

Disagree

Strongly

Not Applicable

1

2

3

4

5

137 I was homesick

Strongly Agree

Agree

Disagree

Strongly

Not Applicable

(1)

2

3

4

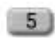

138 I struggled with my internal motivation
Strongly Agree
Agree
Disagree
Strongly
Disagree
Not Applicable
1
2
3
4
5

139 Stress management was an issue

Strongly Agree

Agree

Disagree

Strongly

Not Applicable

1

2

3

4

5

140

It became difficult to keep positive 


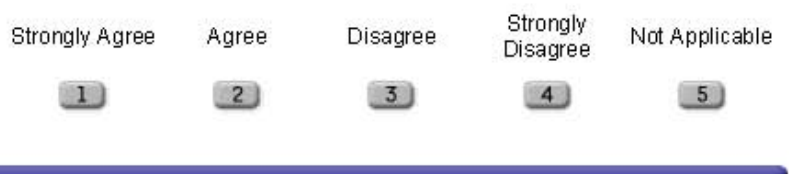

141 Lack of support

Strongly Agree Agree Disagree $\begin{gathered}\text { Strongly } \\ \text { Disagree Not Applicable }\end{gathered}$

$12 \quad 2 \quad 3 \quad 5 \quad 5$

142 Drinking alcohol

Strongly Agree Agree Disagree $\begin{gathered}\text { Strongly Not Applicable } \\ \text { Disagree }\end{gathered}$

$\begin{array}{llll}1 & 2 & 3 & 4\end{array}$

143 Hard time keeping up with my social life

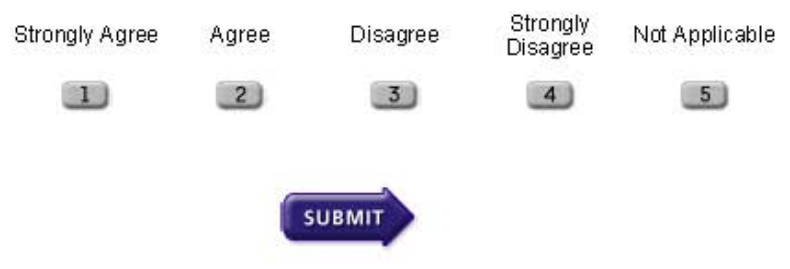

Survey Page 16

\section{Motivations, Factors and Issues Concerning}

Students at West Virginia University

\section{Challenges Faced at wru}

Instruetions: Using the following Likert scale, indicate the challenges you faced at WVU. Indicate your opinion by clicking on the button that that best correspond to your response: 1 - Strongly Agree, 2 - Agree, 3 - Disagree, 4 - Strongly Disagree, or 5 - Not Applicable. 
144 Hard time with new responsibilities

144 Hard time with new respongibilities

$\begin{array}{ccccc}\text { Strongly Agree } & \text { Agree } & \text { Disagree } & \begin{array}{c}\text { Strongly } \\ \text { Disagree }\end{array} & \text { Not Applicable } \\ 1 & 2 & 3 & 4 & 5\end{array}$

\section{I was immature}

$\begin{array}{ccccc}\text { Strongly Agree } & \text { Agree } & \text { Disagree } & \begin{array}{c}\text { Strongly } \\ \text { Disagree }\end{array} & \text { Not Applicable } \\ 1 & 2 & 3 & 4 & 5 \\ & 2 & 4 & \end{array}$

146 Peer pressure was an issue

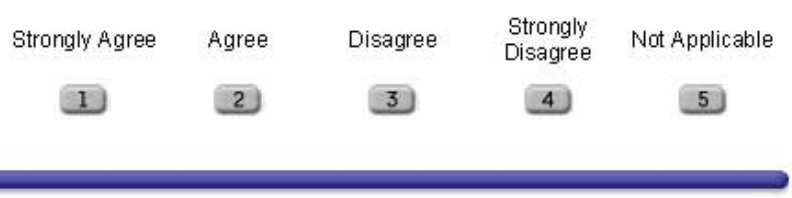

147 Too much freedom

\begin{tabular}{ccccc} 
Strongly Agree & Agree & Disagree & $\begin{array}{c}\text { Stongly } \\
\text { Disagree }\end{array}$ & Not Applicable \\
1 & 2 & 3 & 4 & 5 \\
\hline
\end{tabular}

148 Balance of work and school became too much

\begin{tabular}{ccccc} 
Strongly Agree & Agree & Disagree & $\begin{array}{c}\text { Strongly } \\
\text { Disagree }\end{array}$ & Not Applicable \\
\hline 1 & 2 & 3 & 4 & 5 \\
\hline
\end{tabular}

149 Organizational skills

$\begin{array}{ccccc}\text { Strongly Agree } & \text { Agree } & \text { Disagree } & \begin{array}{c}\text { Strongly } \\ \text { Disagree }\end{array} & \text { Not Applicable } \\ 1 & 2 & 3 & 4 & 5\end{array}$


150 Time management was an issue
Strongly Agree
Agree
Disagree
Strongly
Disagree
Not Applicable
1
2
3
4.
5

151 What is your age range?
- $18-20$
- 21-24
- 25-27
- 28 and up

152

How do you describe your race?

American Indian or Alaskan Native

- Asian

- Black / African American

- Native Hawaiian or other pacific Islander

White/Caucasian

\section{Motivations, Factors and Issues Concerning}

Students at West Virginia University

153

How do you describe your ethnicity?

- Hispanic or Latino

- Non-Hispanic or Latino

154

What is your state of residence? 
155

What do you consider your Socio-economic status to be?

Upper Middle

- Lower Middle

- Working

Working Poor

- Underclass

156

What is your grade point average range?
- $3.5-4.0$
(- $3.0-3.49$
2.5-2.9
Below - 2.4

157

What motivates you to pursue a degree the most?
Money
- Stability
- Personal Goals
- Security

158

What changes would you prefer to see next year?

- Parking availability

- Travel opportunity

- Financial assistance

159

Which college are you currently a part of?

- Davis College of Agriculture, Natural Resources, and Design

- Eberly College of Arts and Sciences

- College of Business and Economics 


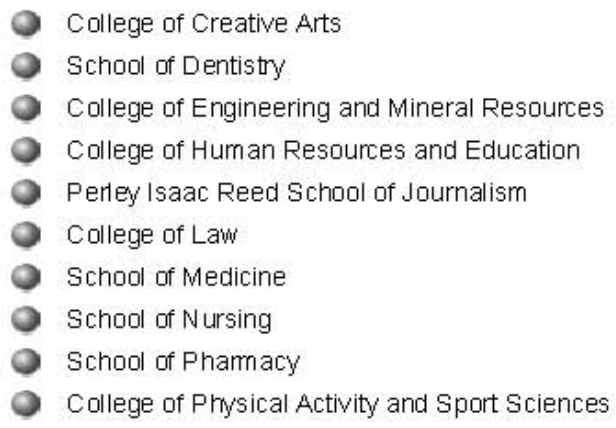

Are you a first generation college student?

\section{YES NO}

161

Did you take Advanced placement dasses in High school?

YES NO

162 If yes, did theyhelp you in preparation for college?

YES NO

Please Continue to the next page.

\section{Motivations, Factors and Issues Concerning Students at West Virginia University}

Please choose from the following answers to the given questions that best fit how you feel, you may have more than one answer 
163 Your parents provided support through
Motivation
Financials
Study skills
Other

164

These individuals have encouraged me to continue my education
Parents
Teachers
Professors
Advisors
Friends
Family

165

What are some study techniques you have used?

Study-Group

Library Alone

Friends

Family

(1) Professors

166 Additional Comments: 
If you have questions about the questionnaire please contact:

Jeremy Kelly

Graduate Student

Agricultural and Extension Education

jkelly5@mix.wvu.edu

(304) $293-5661$ 
VITA

Jeremy L. Kelly

May 2003

Graduated Waynesburg Central High School

December 2008

Graduated Bachelor of Science in Agricultural and Extension Education West Virginia University

May 2010

Graduated Master of Science in Agricultural and Extension education West Virginia University 